UNIVERSIDADE DE SÃO PAULO

FACULDADE DE ECONOMIA, ADMINISTRAÇÃO E CONTABILIDADE

DEPARTAMENTO DE ADMINISTRAÇÃO

PROGRAMA DE MESTRADO PROFISSIONAL EM EMPREENDEDORISMO

\title{
Renato Marques
}

Para além da molécula:

paradoxos da gestão da inovação na indústria farmacêutica 
Prof. Dr. Vahan Agopyan

Reitor da Universidade de São Paulo

Prof. Dr. Fabio Frezatti

Diretor da Faculdade de Economia, Administração e Contabilidade

Prof. Dr. Moacir de Miranda Oliveira Junior

Chefe do Departamento de Administração

Prof. Dr. Marcelo Caldeira Pedroso

Coordenador do Programa de Mestrado Profissional em Empreendedorismo 
RENATO MARQUES

Para além da molécula:

paradoxos da gestão da inovação na indústria farmacêutica

Versão corrigida

Dissertação apresentada ao Departamento de Administração da Faculdade de Economia, Administração e Contabilidade da Universidade de São Paulo para o Programa de Mestrado Profissional em Empreendedorismo como requisito parcial para a obtenção do título de Mestre em Ciências.

Orientadora: Profa. Dra. Lisete Barlach 
Catalogação na Publicação (CIP)

Ficha Catalográfica com dados inseridos pelo autor

Marques, Renato.

Para além da molécula: paradoxos da gestão da inovação na indústria farmacêutica / Renato Marques. - São Paulo, .

$120 \mathrm{p}$.

Dissertação (Mestrado) - Universidade de São Paulo, .

Orientador: Lisete Barlach.

1. Inovação. 2. Gestão da inovação. 3. Indústria farmacêutica. I. Universidade de São Paulo. Faculdade de Economia, Administração e Contabilidade. II. Título. 
Aos meus filhos, Gabriel e Débora, razão de tudo o que faço, na esperança de, um dia, chegar a ser o pai que merecem À minha esposa, Vanessa, por mais uma maratona que corremos lado a lado 



\section{AGRADECIMENTOS}

Agradeço, primeiramente, à minha família, pelo apoio e compreensão ao longo dessa jornada. Pela generosidade de compreender a relevância dessa fase da minha vida e contribuírem com amor e acolhimento nos momentos difíceis.

Aos colegas de trabalho, em duas empresas diferentes, que viveram de perto meus dias de pesquisa e contribuíram com observações e apontamentos valiosos.

Aos professores e colegas do programa de Mestrado Profissional em Empreendedorismo, pela generosidade de compartilhar seus conhecimentos e experiências ao longo do curso.

Aos entrevistados dos estudos de caso, pelo tempo e atenção dedicados. Conhecer suas histórias foi uma experiência muito gratificante.

À minha orientadora, Profa. Dra. Lisete Barlach, pelo suporte, dedicação e encorajamento durante todo o processo, especialmente nos momentos em que foi preciso resiliência para seguir. 



\section{RESUMO}

Marques, R. (2021). Para além da molécula: paradoxos da gestão da inovação na indústria farmacêutica. (Dissertação de Mestrado). Faculdade de Economia, Administração e Contabilidade da Universidade de São Paulo. São Paulo.

A velocidade das transformações promovidas pelo avanço tecnológico tem provocado profundo impacto em todos os setores da economia. Para a indústria farmacêutica, a transformação digital veio acrescentar complexidade a um cenário em ebulição pela alteração na relação de forças no sistema de saúde no Brasil. Lançar seguidamente novas moléculas já não representa garantia de sucesso e faturamento, dado o contexto de reembolso e financiamento dos tratamentos médicos no país. Por meio de um estudo de múltiplos casos, esta dissertação descreveu e analisou o processo de gestão de inovação por três empresas que têm operação comercial direcionada a cuidados de saúde e se relacionam com semelhantes grupos de interesse neste segmento. $\mathrm{O}$ estudo destes casos buscou entender os caminhos da inovação além da molécula na saúde e os de que maneira estes se contrapõem aos métodos tradicionalmente seguidos por grandes farmacêuticas. Por meio desta análise, foi possível observar que a nova relação de forças dentro do sistema de saúde demanda uma maior compreensão da jornada do paciente para busca de geração de valor compartilhado entre os diferentes stakeholders do setor. Os resultados também demonstraram um forte apego da indústria farmacêutica aos processos que alcançaram sucesso no passado, muitas vezes sem uma análise de sua adequação para o contexto atual.

Palavras-chave: Inovação, Gestão da Inovação, Indústria Farmacêutica, Inovação além da molécula, Armadilha do sucesso 


\begin{abstract}
Marques, R. (2021). Beyond the molecule: paradoxes of innovation management in the pharmaceutical industry. (Dissertação de Mestrado). Faculdade de Economia, Administração e Contabilidade da Universidade de São Paulo. São Paulo.
\end{abstract}

The speed of changes brought by technological advances has had a profound impact on all sectors of the economy. For the pharmaceutical industry, the digital transformation has added complexity to an unstable scenario due to changes in the balance of forces in the brazilian health system. Launching new molecules, repeatedly, is no longer a guarantee of success and revenue, given the context of reimbursement and financing of medical treatments in the country. Through a multiple case study, this dissertation described and analyzed the innovation management process developed by three companies that have a commercial operation directed to health care and are related to similar interest groups in this segment. The study of these cases sought to understand the paths of innovation beyond the molecule in health and the ways in which these are opposed to the methods traditionally followed by large pharmaceutical companies. Through this analysis, it was possible to observe that the new balance of strength within the health system demands a greater understanding of the patient's journey to seek shared value generation among the different stakeholders in the sector. The results also demonstrated a strong attachment of the pharmaceutical industry to processes that have been successful in the past, often without an analysis of their suitability for the current context.

Keywords: Innovation, Innovation Management, Pharmaceutical Industry, Innovation beyond the molecule, Success trap 


\section{LISTA DE ABREVIATURAS E SIGLAS}

ABHH Associação Brasileira de Hematologia, Hemoterapia e Terapia Celular ANS Agência Nacional de Saúde

ANVISA Agência Nacional de Vigilância Sanitária

Conitec Comissão Nacional de Incorporação de Tecnologias no SUS

ePRO Eletronic Patient Reported Outcomes

FAPESP Fundação de Amparo à Pesquisa do Estado de São Paulo

FDA Food and Drug Administration

FFMUSP Fundação Faculdade de Medicina da USP

FMVZ Faculdade de Medicina Veterinária e Zootecnia da USP

HCFMUSP Hospital das Clínicas da Faculdade de Medicina da USP

ICESP Instituto do Câncer do Estado de São Paulo

InRad Instituto de Radiologia

OMPI Organização Mundial da Propriedade Intelectual

OMS Organização Mundial da Saúde

P\&D Pesquisa e Desenvolvimento

PIPE Pesquisa Inovativa em Pequenas Empresas

PPP Parceria Público-Privada

PRO Patient Reported Outcomes

SUS S Sistema Único de Saúde

USP Universidade de São Paulo

WIPO World Intellectual Property Organization 


\section{LISTA DE TABELAS}

Tabela 01. Dez empresas que mais investem em P\&D

20

Tabela 02. Matriz de amarração 63

Tabela 03. Casos escolhidos, perfil 2 65

Tabela 04. Lista de entrevistados 67

Tabela 05. Barreiras internas no caso 01 110 


\section{LISTA DE IMAGENS}

Imagem 01. Contribuição global, por país ou região, em patentes farmacêuticas 22

Imagem 02. Pareceres de incorporação emitidos pela Conitec em 2020 26

Imagem 03. Representação genérica da jornada do paciente 28

Imagem 04. Fatores que afetam a inovação no ambiente corporativo 37

Imagem 05. Evolução da participação dos medicamentos genéricos - 2001/2005 (em MM

US\$) 43

Imagem 06. Comentário de diretor da Anvisa sobre a incorporação de Spinraza 48

Imagem 07. Indústria farmacêutica e stakeholders primários 49

Imagem 08. Necessidades de saúde e bem-estar atendidas por soluções digitais e distribuição entre players em Digital Health 56

Imagem 09. Procedimento Metodológico 61

Imagem 10. Empresa 01 na perspectiva da jornada do paciente 105

Imagem 11. Empresa 02 na perspectiva da jornada do paciente 106

Imagem 12. Empresa 03 na perspectiva da jornada do paciente 106 

SUMÁRIO

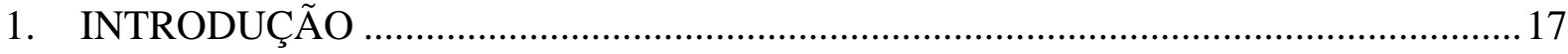

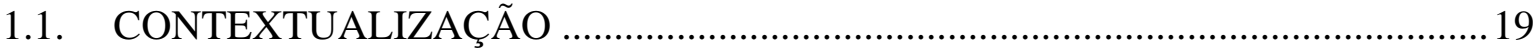

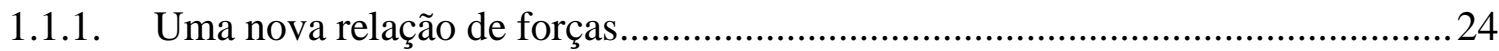

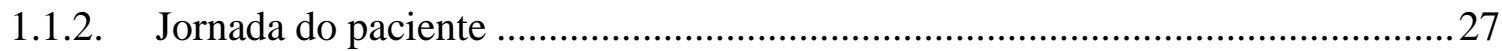

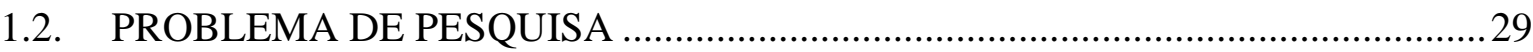

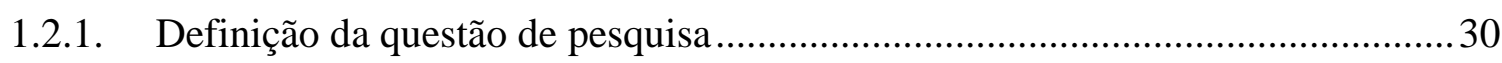

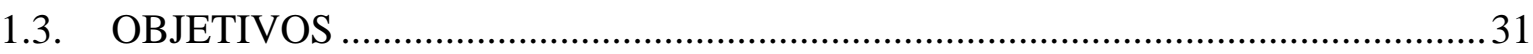

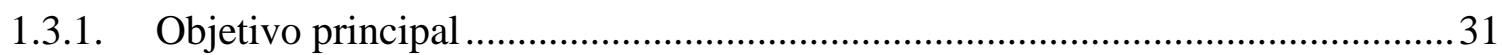

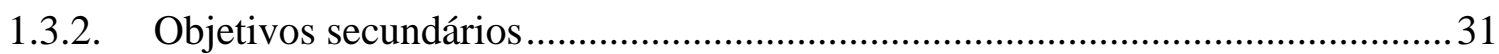

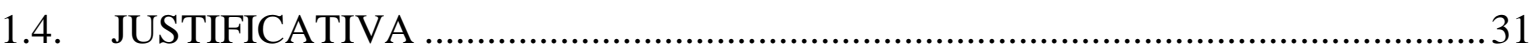

1.4.1. Relato da experiência..................................................................................... 31

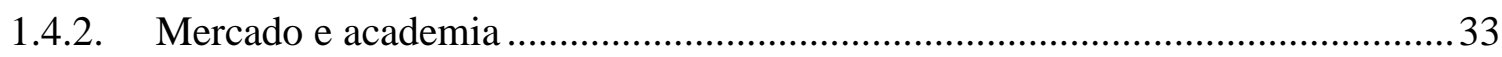

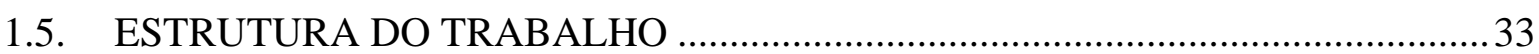

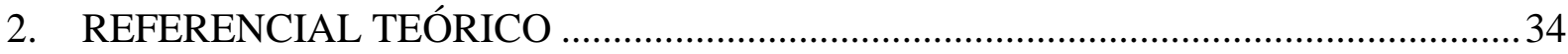

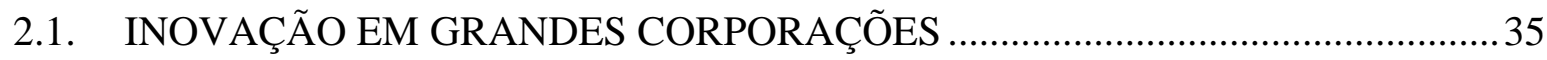

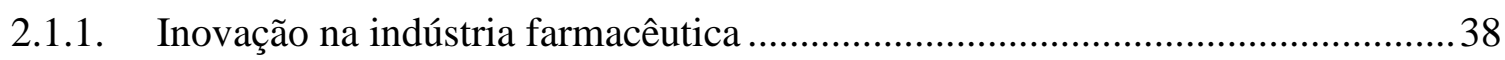

2.1.2. Proteção intelectual no setor farmacêutico …………………………………....... 39

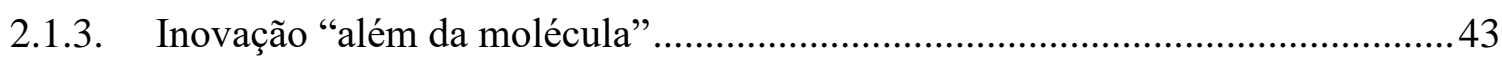

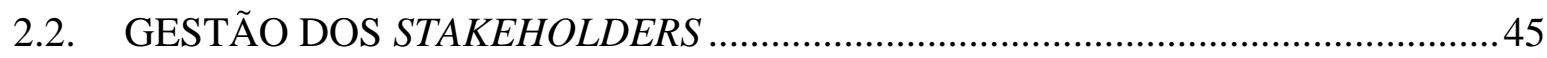

2.2.1. Representatividade dos stakeholders ............................................................... 48

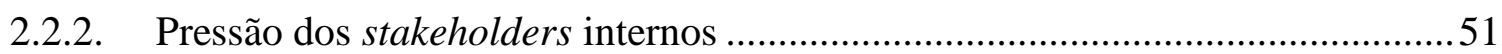

2.3. DIGITAL HEALTH E OPORTUNIDADES ALÉM DA MOLÉCULA.......................51

2.3.1. Modelo de identificação de oportunidades de inovação........................................53

2.3.2. Transformação digital na saúde ...................................................................

2.3.3. Barreiras em Digital Health para as indústrias farmacêuticas .............................56

2.3.4. A armadilha do sucesso para a liderança.........................................................57

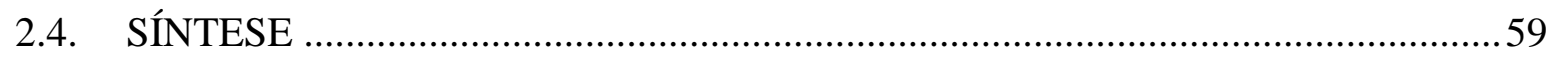

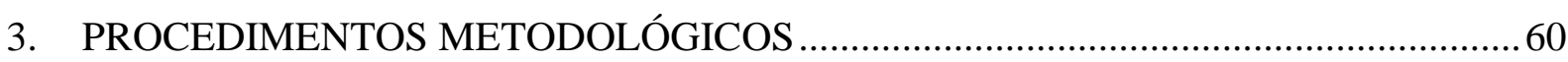

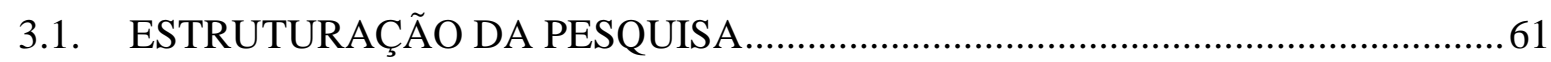

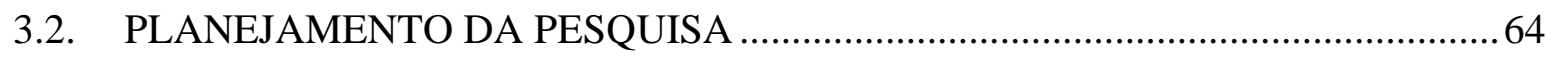

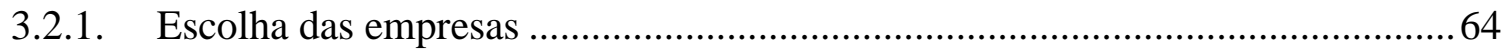

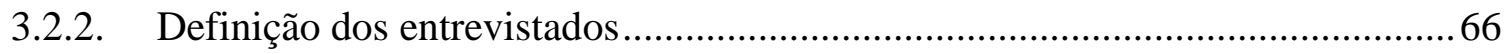

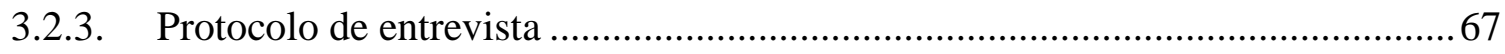




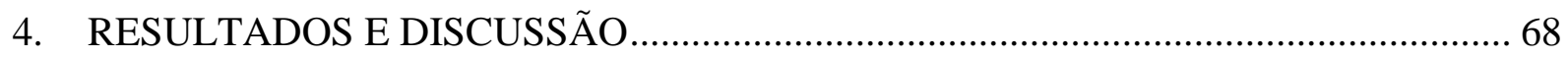

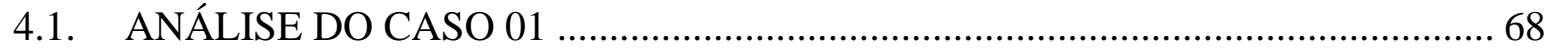

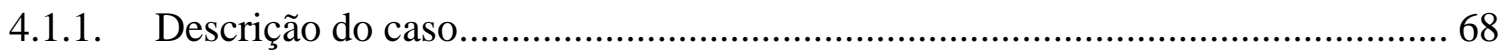

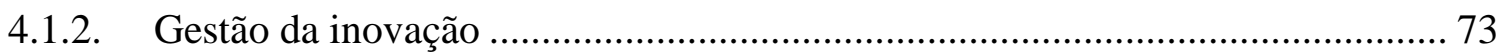

4.1.3. Gestão estratégica dos stakeholders .................................................................. 75

4.1.4. Transformação digital e armadilha do sucesso ............................................... 79

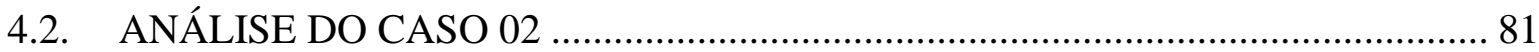

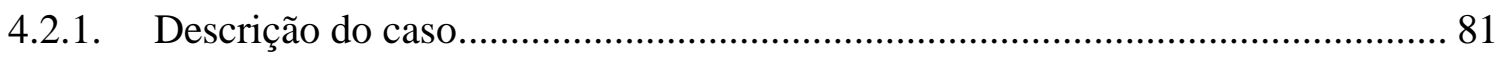

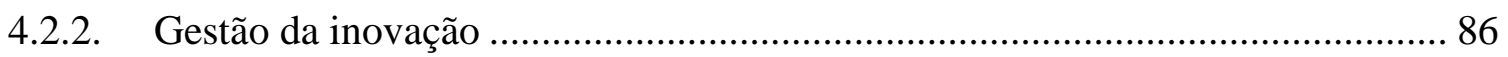

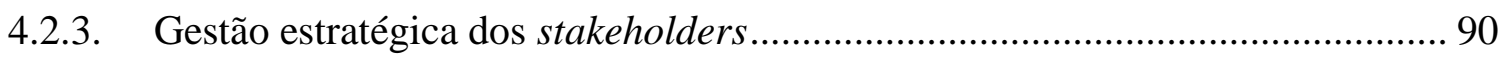

4.2.4. Transformação digital e armadilha do sucesso ............................................... 92

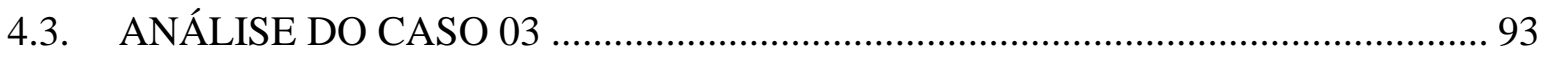

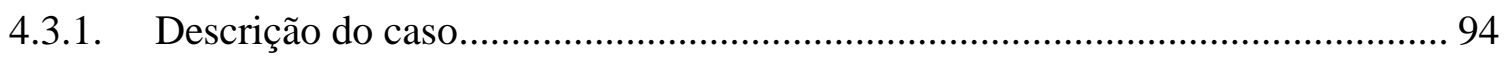

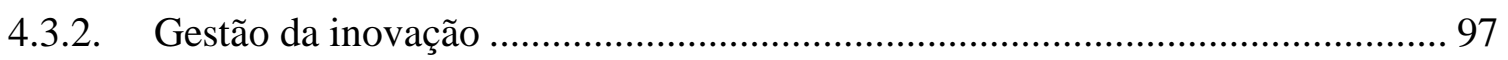

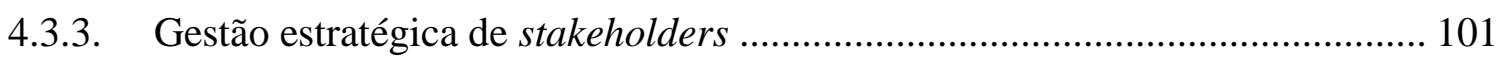

4.3.4. Armadilha do sucesso .................................................................................. 103

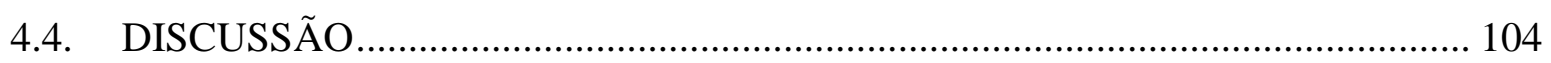

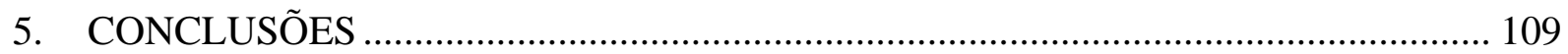

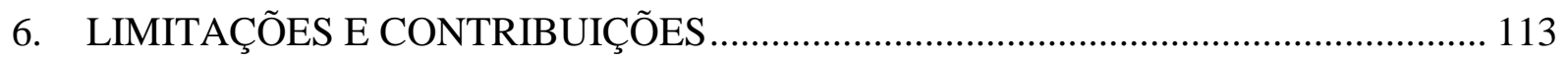

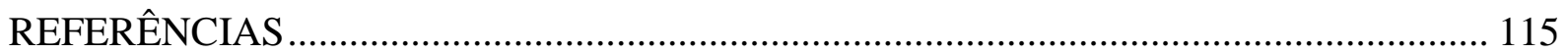




\section{INTRODUÇÃO}

Com um importante atraso em relação a outros setores, a revolução digital chegou ao setor farmacêutico. Embora para o segmento de saúde em geral essa já seja uma realidade consolidada, para as grandes empresas farmacêuticas ainda é algo novo. A maior parte de suas práticas de mercado ainda remonta àquelas utilizadas durante grande parte do século $\mathrm{XX}$ em que praticamente todo o relacionamento com grupos de interesse é baseado na icônica figura do representante comercial.

Paralelamente, o setor de saúde vive uma verdadeira "invasão" de empresas não tradicionalmente ligadas ao segmento farmacêutico. Corporações como Samsung, Google e Amazon ampliam seus investimentos no desenvolvimento de soluções digitais para saúde e bem-estar, ameaçando a exclusividade que a indústria farmacêutica tinha sobre o segmento. Não por acaso, das nove empresas homologadas pelo Food and Drug Administration (FDA, entidade responsável pela aprovação de medicamentos nos Estados Unidos) no recém-iniciado programa piloto de pré-certificação para softwares de Digital Health, apenas duas são tradicionalmente ligadas à saúde - a suíça Roche e a norte-americana Johnson \& Johnson (U.S. DEPARTMENT OF HEALTH AND HUMAN SERVICES, 2017).

Ao mesmo tempo, ainda que estas corporações não tenham acompanhado de perto as evoluções das tecnologias disponíveis, o consumidor também mudou. Suas expectativas, desejos e percepções foram alteradas pelo alto volume de informações disponíveis. Da mesma forma, há mudanças na relação de forças no sistema brasileiro de saúde. Não se trata apenas de demonstrar o valor do tratamento aos consumidores, nesse caso, pacientes, mas também a médicos, hospitais, clínicas, planos de saúde e governos, uma vez que todos eles interferem no processo de tomada de decisão e compra do medicamento. Às empresas já não basta o

posicionamento tradicional. É preciso mostrar conexão com a perspectiva dos clientes e demonstrar que sua reputação não é baseada apenas no reforço de mensagens anteriormente consolidadas.

Para estas companhias, no entanto, além do reforço de competitividade nos mercados em que já atuam, há o crescente atrativo do mercado de digital health, ligado ao desenvolvimento de soluções tecnológicas para processos de saúde. Estimativa do estudo Deloitte Global Life Sciences Outlook aponta que até o ano de 2024, esse segmento corresponda a um faturamento global US\$ 595 bilhões - dez vezes superior ao registrado por este mercado em 2015 (DELOITTE, 2018). 
Neste cenário desafiador, as farmacêuticas são constantemente pressionadas a reagir. Por um lado, precisam reforçar sua posição competitiva no mercado em que já atuam. Sua resposta, no entanto, segue sendo a mesma que as colocou nessa posição - desenvolvendo e lançando continuamente novas moléculas. Presas a modelos bem-sucedidos no passado, a chamada "armadilha do sucesso" (KAUFMANN, 2004), repetem a prática de investir ininterruptamente na criação de novas propriedades intelectuais, apostando na repetição dos resultados positivos que podem ser coletados durante o período de proteção da patente ${ }^{1}$.

Por outro lado, sofrem com restrições regulatórias que impedem uma abordagem mais agressiva no nascente mercado de soluções digitais. Acostumadas a processos desenhados para gerenciar o longo e custoso processo de desenvolvimento de medicamentos, não conseguem estruturar processos de inovação "além da molécula", produtos, serviços e modelos de negócio que cumpram um papel complementar ao dos fármacos na cobertura da jornada do paciente. Como resultado deste paradoxo, cresce entre seus stakeholders a pressão por inovação nos processos e modelos operacionais destas empresas, intimamente ligados a estruturas conservadoras.

Considerando o contexto do mercado em constante transformação, este estudo buscará responder ao seguinte problema de pesquisa: quais oportunidades se abrem para a inovação além da molécula de forma que as empresas sejam bem-sucedidas no atual contexto da saúde no Brasil?

Sob esta perspectiva, o enfoque deste estudo será avaliar a atuação "além da molécula", modelo que se apresenta como uma ruptura nas concepções do segmento, acostumado a traduzir inovação como o investimento em Pesquisa e Desenvolvimento (P\&D). Para descobrir e efetivar estas oportunidades, no entanto, estas corporações precisam se abrir para um novo perfil de desenvolvimento. Ampliar sua perspectiva de inovação focada na criação de novos medicamentos por meio de $\mathrm{P} \& \mathrm{D}$ e buscar tecnologias que transformem sua maneira de atuar e permitam uma melhor compreensão deste novo perfil do consumidor e, assim, inovar na abordagem ao mercado.

\footnotetext{
${ }^{1}$ No sistema atual, após o registro de uma patente de medicamento, esta tem garantia de proteção por um período de 20 anos. Considerando o alto grau de competitividade científica do segmento, se trata de um processo do qual as farmacêuticas se utilizam como uma espécie de reserva de mercado (AKKARI et al., 2016).
} 


\subsection{CONTEXTUALIZAÇÃO}

Vários autores já definiram o momento no qual vivemos atualmente como a era da informação, ou era do conhecimento, ou uma série de outros termos que buscam explicar o contexto de constante transformação que as empresas precisam enfrentar agora. Mudanças que impactam toda a sociedade não são mais definidas somente por marcos globais, como as grandes guerras mundiais, ou por eventos deterministas - o fim do período Cretáceo pela queda de um meteoro, por exemplo. Evoluções tecnológicas são praticamente contínuas e reduzem progressivamente o tempo de reação das empresas em ambiente competitivo.

Schwab (2016) denominou este contexto, em publicação realizada após o Fórum Econômico Mundial de 2016, como A Quarta Revolução Industrial.

Somos testemunhas de mudanças profundas em todos os setores, marcadas pelo surgimento de novos modelos de negócios, pela descontinuidade dos operadores e pela reformulação da produção, do consumo, dos transportes e dos sistemas logísticos. Na sociedade, há uma mudança de paradigma em curso no modo como trabalhamos e nos comunicamos, bem como nas maneiras de nos expressarmos, nos informarmos e nos divertirmos. Igualmente, está em andamento a reformulação de governos e de nossas instituições; o mesmo ocorre, entre muitos outros, com os sistemas de educação, de saúde e de transportes. (SCHWAB, 2016, p.09)

Sob esta perspectiva, é notório que diversos segmentos da economia foram impactados pela aceleração no ritmo das mudanças econômicas e sociais dos últimos anos. Em muitos casos, a redução no tempo disponível para reação às mudanças ocorridas no mercado foi determinante para perda de mercado e até mesmo para o fim de empresas consolidadas².

Há algo além das mudanças e da velocidade com que ocorrem, no entanto. A natureza das pesquisas e das evoluções tecnológicas agora também é dinâmica, expansiva e recombinante (SCHWAB, 2018). Elas impactam setores que ainda eram marcados por modelos tradicionais de P\&D, como o da Saúde. Soluções digitais são estruturadas não apenas para evoluir equipamentos eletrônicos, mas para otimizar o desempenho de medicamentos ou reestruturar a lógica de tratamentos, priorizando uma abordagem holística, que considere toda a jornada do paciente, desde a prevenção às doenças até a manutenção da abordagem

\footnotetext{
${ }^{2}$ Um exemplo significativo é o da disputa entre Nokia e Apple pela liderança do mercado de smartphones. Até o lançamento do Iphone, em 2007, a Nokia ocupava a liderança do mercado, tanto do ponto de vista de vendas como da criação de tendências. Alguns anos após o lançamento do aparelho da Apple, no entanto, a empresa perdeu cerca de $90 \%$ do valor de mercado. (LEE, 2013).
} 
terapêutica. Novas tecnologias oferecem caminhos alternativos para o desenvolvimento de drogas e para mensuração do seu impacto.

A quarta revolução industrial, no entanto, não diz respeito apenas a sistemas e máquinas inteligentes e conectadas. Seu escopo é muito mais amplo. Ondas de novas descobertas ocorrem simultaneamente em áreas que vão desde o sequenciamento genético até a nanotecnologia, das energias renováveis à computação quântica. $O$ que torna a quarta revolução industrial fundamentalmente diferente das anteriores é a fusão dessas tecnologias e a interação entre os domínios físicos, digitais e biológicos. (SCHWAB, 2016, p.11)

Cada vez mais, o ambiente mercadológico da saúde tem se tornado complexo e altamente competitivo. Com mais de um século de desenvolvimento contínuo de novos medicamentos, as indústrias farmacêuticas acreditam que já definiram seus processos de criatividade e inovação. Mas, hoje, seus modelos tradicionais não são mais suficientes. O perfil dos tratamentos mudou, o número de doenças raras, que atingem grupos demográficos específicos, cresceu e é preciso encontrar soluções novas para velhos problemas. Em um contexto de instabilidade e incerteza, as empresas do segmento são chamadas a inovar em todos os seus processos.

Regularmente, as empresas farmacêuticas se posicionam entre as que mais investem em inovação no mundo. Segundo dados do estudo Global Innovation 1000, da consultoria PriceWaterhouseCoopers (2018), três empresas do setor estão entre as dez empresas que mais investem em pesquisa e inovação, sendo o segmento com o maior número de representantes neste grupo. Mais que isso, o estudo projeta que o setor será o líder nesta perspectiva entre todos os segmentos da economia até 2020.

Tabela 01 - Dez empresas que mais investem em P\&D

\begin{tabular}{|c|c|c|c|c|}
\hline Ranking 2018 & Empresa & Setor & $\begin{array}{c}\text { Total investido } \\
\text { em P\&D }\end{array}$ & $\begin{array}{l}\text { \% do faturamento } \\
\text { investido em P\&D }\end{array}$ \\
\hline 1 & Amazon & Varejo & 22,6 & $12,70 \%$ \\
\hline 2 & Alphabet & Software e Serviços & 16,2 & $14,60 \%$ \\
\hline 3 & Volkswagen & Automóveis & 15,8 & $5,70 \%$ \\
\hline 4 & Samsung & Hardware & 15,3 & $6,80 \%$ \\
\hline 5 & Intel & Semicondutores & 13,1 & $20,90 \%$ \\
\hline 6 & Microsoft & Software e Serviços & 12,3 & $13,70 \%$ \\
\hline 7 & Apple & Hardware & 11,6 & $5,10 \%$ \\
\hline 8 & Roche Holding & Farmacêutica & 10,8 & $18,90 \%$ \\
\hline 9 & Johnson \& Johnson & Farmacêutica & 10,6 & $13,80 \%$ \\
\hline 10 & Merck & Farmacêutica & 10,2 & $25,40 \%$ \\
\hline
\end{tabular}

Fonte: Estudo Global Innovation 2018 
Dados publicados pela empresa EMIS Insights (2018) mostram que, em 2017, o Brasil alcançou o posto de sexto maior mercado farmacêutico do mundo. De acordo com a consultoria, o resultado, que representa US\$33,1 bilhões em vendas, será um grande propulsor de novos investimentos no setor no país. Paralelamente, no entanto, tamanha atratividade resulta em importantes movimentações no cenário, levados pelo aumento da competitividade entre empresas nacionais e multinacionais em operação no país.

Empresas farmacêuticas são, em sua maioria, companhias que têm no P\&D a base de alavancagem do seu negócio - inovação, neste contexto, representava desenvolver novos produtos. Tradicionalmente, a competição, no segmento, dependia essencialmente da criação de novos medicamentos e seu faturamento, sua margem de lucro, estava consolidada na criação e registro de novas patentes, sendo o período de proteção intelectual a delimitação do ciclo de vida do produto (DIMASI; HANSEN; GRABOWSKI, 2003). A questão, no entanto, é que a era dos grandes "blockbusters" acabou no setor. As maiores necessidades terapêuticas não atendidas estão nas chamadas doenças raras $^{3}$. Para atendê-las, no entanto, as indústrias farmacêuticas precisam desenvolver soluções específicas que alcançam grupos menores de pacientes. E o risco do desenvolvimento é o mesmo. Estima-se que a cada 100.000 compostos descobertos, apenas um passa por todas as etapas de testes clínicos para chegar ao mercado, a um custo que oscila entre US\$ 800 mil e US\$ 1,5 bilhão (LIMA et al., 2003; DIMASI; HANSEN; GRABOWSKI, 2003).

Com efeito, ainda que a firma intensiva em pesquisa seja a agência mais efetiva da inovação, várias outras instituições participam do processo de $\mathrm{P} \& \mathrm{D}$ farmacêutica, tais como instituições acadêmicas, instituições públicas e privadas de pesquisa, laboratórios públicos, como os $\mathrm{NIHs}^{4}$ norte-americanos, além de, recentemente, pequenas firmas de biotecnologia. Mas o aspecto central repousa na motivação das firmas para inovar. Inovações envolvem incertezas técnico-científicas e comerciais e aceitação de riscos financeiros por parte das empresas, que respondem por meio do investimento de capital para o desenvolvimento de novos produtos e processos em antecipação a consideráveis retornos, mas dependendo do seu fluxo de caixa. (BASTOS, 2005, p.279)

\footnotetext{
${ }^{3}$ De acordo com a Organização Mundial de Saúde (OMS), doenças raras são aquelas que afetam até 65 pessoas em cada 100 mil indivíduos, ou seja, 1,3 para cada 2 mil pessoas. Esta definição, no entanto, varia entre os diferentes governos para fins regulatórios. No Brasil, a Agência Nacional de Vigilância Sanitária (Anvisa) utiliza o mesmo conceito difundido pela OMS.

${ }^{4} \mathrm{NIH}$ - National Institutes of Health. Centros norte-americanos de pesquisa em saúde, mantidos em parte pelo governo dos EUA e em parte por hospitais e outros órgãos do segmento. Trabalham em estudos clínicos em conjunto com indústrias farmacêuticas.
} 
Naturalmente, outros mercados também têm a competição baseada em inovações tecnológicas (BASTOS, 2005). Neste setor, no entanto, estas, acompanhadas dos investimentos em $\mathrm{P} \& \mathrm{D}$, são a base da competição e possuem elevado valor estratégico, o que se deve à natureza específica da demanda, ao elevado impacto social e à situação de oligopólio diferenciado (DOS SANTOS; FERREIRA, 2012).

Especialmente quando consideradas as grandes empresas multinacionais do setor, fica ainda mais clara a distância entre a inovação que é produzida nos laboratórios de pesquisa e o modelo de gestão do negócio. No caso de países como o Brasil, isso é reforçado, ainda mais, pelo fato de que o desenvolvimento de novos produtos ocorre, em geral, nas matrizes (a maioria europeias ou norte-americanas), e a operação - especialmente a gestão de marketing e a distribuição logística - é conduzida nas filiais, onde os produtos são efetivamente comercializados (AKKARI et al., 2016). Para as indústrias locais, o foco está na produção de genéricos $^{5}$ ou na distribuição de medicamentos desenvolvidos fora do país. O reflexo é, localmente, um baixo volume de registro de novos fármacos. Destaca-se, portanto, a oportunidade de inovação "além da molécula".

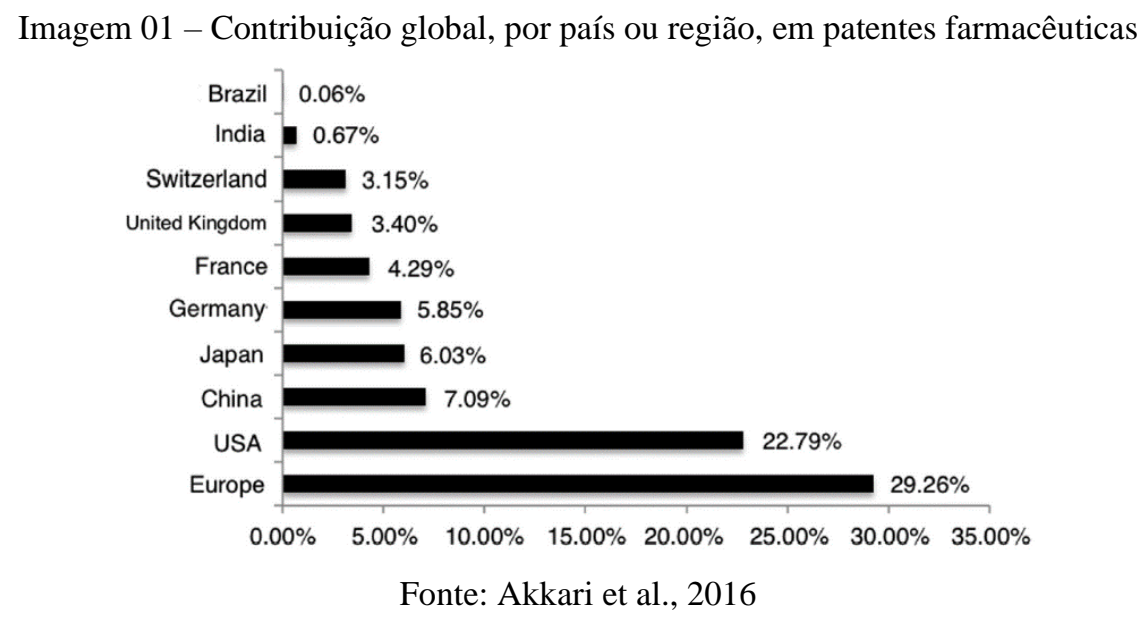

“Além da molécula" é como se define a criação de produtos e serviços que cumpram um papel complementar ao dos medicamentos. Para descobrir e efetivar estas oportunidades, no entanto, estas corporações precisam se abrir para um novo perfil de desenvolvimento: ampliar sua perspectiva de inovação focada na criação de medicamentos por meio de pesquisa

\footnotetext{
${ }^{5}$ Após o final do período legal de proteção da patente, abre-se a possibilidade de reprodução do fármaco por outras empresas, sem a utilização do nome comercial. A estes produtos, nomeados apenas a partir do princípio ativo, dá-se o nome de genéricos. Esta dinâmica do mercado será explicada mais a frente, sob a perspectiva de ameaça à prática adotada pelo mercado.
} 
e buscar tecnologias que transformem sua maneira de atuar e permitam uma melhor compreensão deste novo perfil do consumidor e, assim, inovar na abordagem ao mercado.

Especificamente no Brasil, embora o governo tenha ampliado o programa de investimento para construção de infraestrutura do setor (cerca de $\mathrm{R} \$ 4,6$ bilhões investidos nos últimos nove anos), localmente estas empresas trabalham apenas no âmbito de geração de demanda e distribuição (BASTOS, 2005). Assim, o foco na inovação local e regional se dá muito mais na criação e ampliação de programas complementares ao tratamento, o que amplia o leque de oportunidades para criação de novos produtos/serviços e para aproximação dos clientes.

Diferente do que ocorre com o desenvolvimento de novos medicamentos, o custo de desenvolvimento de inovações além da molécula não é proibitivo para as operações locais das farmacêuticas multinacionais. Como se verá mais a frente, algumas mudanças em legislações locais - como a ocorrida no Brasil com a lei dos genéricos no fim dos anos 90 - levaram as indústrias a centralizar o desenvolvimento de medicamentos e o registro internacional de patentes nas matrizes. As inovações além da molécula, em contrapartida, trazem a oportunidade de refletir as especificidades dos mercados locais, alavancando, inclusive, a penetração dos medicamentos nos intricados sistemas nacionais de saúde.

Outro fator significativo no cenário atual é a ampliação do número de startups na área de saúde, que apresentam, ainda que indiretamente em alguns casos, ameaças competitivas às grandes empresas, especialmente no quesito de adesão aos tratamentos. Nos últimos anos, esse cenário se intensificou fortemente com o acirramento da competição, incrementado pela entrada de pequenas biotechs, e os avanços nas áreas de biotecnologia e engenharia genética. Segundo o estudo Liga Insights - Health Techs (LIGA VENTURES, 2018), o Brasil já conta com 263 startups na área de saúde em operação.

A fim de definir um recorte mais específico para este projeto, a pesquisa considerará empresas farmacêuticas brasileiras ou multinacionais, que atualmente já investem no desenvolvimento de novos medicamentos, independente da área terapêutica - oncologia, neurologia, etc. A complexidade de mercado na introdução de novos fármacos, bem como o elevando investimento despendido na criação de moléculas, faz com que a urgência pelas transformações citadas anteriormente amplie o potencial de impacto para este grupo. Além disso, a expansão das pesquisas para doenças consideradas raras faz com que fatores como especificidade da introdução de novos produtos por meio da relação empresa-médico-paciente 
e as necessidades oriundas do perfil do tratamento ampliem as oportunidades de desenvolvimento de produtos e serviços para além da molécula.

\subsubsection{Uma nova relação de forças}

Outro fator importante no contexto da saúde é a intensa reorganização vivida pelo sistema brasileiro de saúde. Atualmente, a decisão pela escolha de determinado medicamento - especialmente em tratamentos de alto custo - considera uma gama ampla de fatores que vai desde o benefício aos pacientes até a sustentabilidade do sistema de saúde como um todo. Desta forma, o conjunto de grupos de interesse envolvidos neste processo é maior e inclui novos atores, que passaram a ter uma força relativa maior na tomada de decisão.

Neste cenário, não se trata apenas de apresentar o valor científico aos médicos, ou os benefícios imediatos e a solidez da marca aos pacientes. Mas, também, a efetivamente demonstrar a relação de custo-efetividade a hospitais, clínicas, planos de saúde e governos, pois todos interferem, em alguma dimensão, na tomada de decisão de acesso ao medicamento. Quando se considera, principalmente, tratamentos de alto custo, cada novo lançamento de produto é imediatamente seguido pela pergunta “quem vai pagar a conta?”. Na prática, significa uma preocupação sistêmica de equilibrar as demandas e garantir acesso a saúde de maneira ampla. Em um país como o Brasil, com sistema de saúde universal, por exemplo, um novo tratamento passa por um processo longo - ainda após sua aprovação regulatória - para ter seu reembolso garantido.

Atualmente, o processo de incorporação de um medicamento ao rol de reembolsados pelo Sistema Único de Saúde (SUS), atualizado em 2019, é uma parte importante da viabilidade do segmento no Brasil. A análise é feita pela Comissão Nacional de Incorporação de Tecnologias no SUS (Conitec), órgão do Ministério da Saúde, que considera diversos fatores para a inclusão de um tratamento à lista de reembolso - o que representa garantia de pagamento.

Nem todos os medicamentos que possuem registro sanitário são automaticamente incorporados ao SUS. É na etapa da seleção de medicamentos que as instâncias gestoras do SUS decidem quais os medicamentos que devem compor o elenco de suas listas oficiais e serem adquiridos e utilizados nas unidades do SUS. O produto da seleção é uma lista constituída por medicamentos considerados necessários para atender às necessidades sanitárias de cada local. A seleção de medicamentos deve se fundamentar nas melhores evidências disponíveis e considerar morbidades prevalentes, eficácia, efetividade, segurança e qualidade do fármaco, 
apresentações farmacêuticas que atendam as necessidades, comodidade posológica, custo e disponibilidade no mercado. (PEPE et al., 2010, p.2408)

Após receber a solicitação de análise da incorporação - que pode vir de diversas fontes, como Sociedades Médicas, Hospitais, do Ministério da Saúde e das próprias indústrias farmacêuticas -, a Conitec faz uma avaliação inicial e publica uma recomendação preliminar favorável ou contrária à incorporação, exclusão ou alteração da tecnologia analisada. Esta recomendação é submetida a uma consulta pública, aberta a toda a sociedade civil na qual são ouvidas as opiniões de todos os agentes envolvidos na jornada do paciente. Incluídos aí os pacientes - em 2020, durante a pandemia de COVID-19, a Conitec, responsável pelo processo, anunciou que seriam ouvidos relatos de pacientes durante a apresentação de um pedido de incorporação ao plenário da comissão.

A partir destas contribuições, a Conitec revisa o processo e encaminha ao Ministério da Saúde uma recomendação final sobre a incorporação. Com isso em mãos, o Secretário de Ciência, Tecnologia, Inovação e Insumos Estratégicos em Saúde do Ministério da Saúde decide se o medicamento será ou não incorporado ao SUS. Uma análise das recomendações da Conitec em 2020 (sejam finais ou iniciais) mostra que a incorporação de novos tratamentos ao SUS está progressivamente mais difícil, seja pelo elevado nível de exigência da agência, seja pela falta de recursos públicos para custear medicamentos cada vez mais caros.

De acordo com os relatórios publicados pela Conitec em $2020^{6}$, foram emitidas recomendações - iniciais ou finais - para 57 solicitações de incorporações, sendo 25 (aproximadamente 44\%) destas solicitadas por indústrias farmacêuticas, das quais 23 pediam análise de inclusão de novos tratamentos (os outros dois casos solicitavam ampliar as indicações reembolsadas). Por sua vez, apenas três destas solicitações (equivalente a 13\%) tiveram parecer inicial favorável por parte da Conitec. Em 65\% dos casos em que o parecer inicial foi negativo, a justificativa dada pela comissão foi relacionada à questão de custo-efetividade do tratamento. Para efeito de comparação, nos pedidos de inclusão de tratamentos no rol de reembolsos do SUS feitos por outras entidades (secretarias do Ministério da Saúde, associações médicas, associações de paciente), o parecer inicial foi favorável em $60 \%$ das vezes.

\footnotetext{
${ }^{6}$ Relatórios para a Sociedade, série de publicações da Conitec com os relatos dos processos de incorporação. Para este trabalho, são considerados os pareceres publicados até 03 de dezembro de 2020
} 
Imagem 02 - Pareceres de incorporação emitidos pela Conitec em 2020

Total de solicitações de incorporação analisadas em 2020 - 57

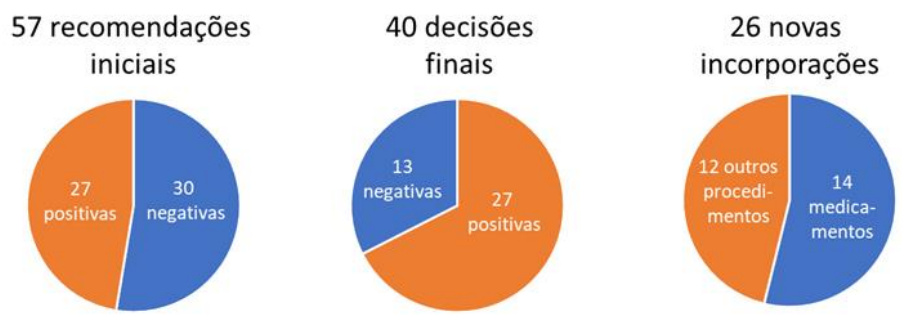

Solicitações de novas incorporações feitas pela indústria farmacêutica em 2020 - 23

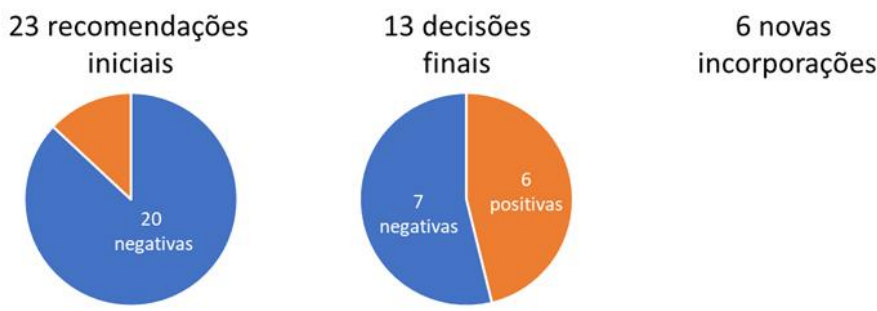

Fonte: Elaborado pelo autor

As análises da Conitec mostram que outros atores ganharam relevância na definição dos tratamentos para o SUS. A Associação Brasileira de Hematologia, Hemoterapia e Terapia Celular (ABHH), entidade médica, enviou quatro solicitações de incorporação ao Ministério da Saúde, das quais três foram aceitas. Mesmo no caso da indústria farmacêutica, houve três casos em que a recomendação inicial foi revertida pela Conitec após o período de consulta pública. Em dois destes, os motivadores foram o engajamento da sociedade (especialmente de associações de pacientes) e a renegociação do preço por parte da empresa solicitante.

Com o crescimento do número de tratamentos disponíveis para doenças raras, bem como tratamentos de longo prazo para doenças agora vistas como crônicas (tratamentos contra determinados tipos de câncer, por exemplo, podem se estender por até cinco anos), agentes públicos buscam antecipar esses movimentos para reduzir o impacto da judicialização ${ }^{7}$, tendo um volume maior de opções padronizadas e adotadas no sistema público. Neste sentido, os agentes públicos criam uma resistência a abordagens das indústrias farmacêuticas, para evitar incorporações indevidas de novos medicamentos.

\footnotetext{
${ }^{7}$ Judicialização é o processo pelo qual o paciente solicita o fornecimento de medicamentos ao governo por via judicial. Havendo prescrição médica emitida por profissional devidamente registrado no conselho profissional responsável, não há nem mesmo a obrigatoriedade de que o medicamento esteja aprovado no Brasil (PEPE et al., 2010). De acordo com dados do Ministério da Saúde, o gasto com tratamentos judicializados - não previstos, portanto, na carta orçamentária - chegou a R\$ 1,4 bilhão em 2018.
} 
Paralelamente, o setor privado de saúde brasileiro também buscou se reorganizar. A figura das operadoras de saúde verticalizadas ${ }^{8}$ consolidou a posição de poder dos pagadores na negociação com as farmacêuticas e operadores dos serviços (DE ALBUQUERQUE, 2006). Ao reduzir a fragmentação dos clientes, esse movimento permitiu a estas entidades que definissem seus próprios protocolos de tratamento, favorecendo critérios de farmacoeconomia como base para as negociações. Assim, redução de internações e facilidade de adesão ao tratamento passam a ser fatores de decisão na escolha de um tratamento - não o medicamento isoladamente, mas a maneira como impacta na qualidade de vida do paciente como um todo.

Não significa que não exista demanda por novos tratamentos. No entanto, para que um tratamento padronizado, já consolidado, seja substituído por um novo, o benefício precisa estar claro e o reembolso previsto. Assim, por consequência, as indústrias farmacêuticas estão sendo chamadas a um novo posicionamento, em que demonstrem conexão com a realidade dos clientes e pacientes e comprovem que sua reputação não é baseada apenas no reforço de mensagens anteriormente consolidadas - também precisam pensar na sustentabilidade do sistema, não só na venda do seu produto. Neste novo posicionamento, precisam compreender todos os fatores que envolvem os passos da jornada do paciente e gerenciar os diferentes stakeholders ao longo dessa jornada para criar valor a todo o sistema.

No mercado de saúde como um todo e especialmente no Brasil, houve um reposicionamento do poder social e político dos operadores da saúde na tomada de decisão por tratamentos e medicamentos. Agentes públicos e da sociedade civil pressionam por redução de custos e ampliação de acesso aos tratamentos, criando resistência à abordagem tradicional das indústrias farmacêuticas de lançamentos subsequentes, evitando incorporações onerosas de novos medicamentos ao rol de medicamentos reembolsados pelo SUS e por operadores de planos de saúde particulares.

\subsubsection{Jornada do paciente}

Parte da reestruturação de forças no segmento se dá pela crescente complexidade do sistema de atenção à saúde no Brasil. Entre a identificação dos primeiros sintomas pelos

\footnotetext{
${ }^{8}$ Operadoras verticalizadas são empresas de planos de saúde que operam com rede própria de hospitais e clínicas. $\mathrm{Na}$ relação com indústrias farmacêuticas, por exemplo, permite negociação centralizada de insumos para todos os pontos de operação da sua rede (DE ALBUQUERQUE, 2006).
} 
pacientes e o efetivo tratamento há um número grande de etapas a serem cumpridas - e todas elas precisam ser formalmente reconhecidas pela agência regulatória correspondente e passar pelo reconhecimento dos agentes pagadores, seja por meio de inclusão no SUS ou reembolso por planos particulares, como explicado anteriormente. O caminho entre a Prevenção e os Cuidados contínuos após o tratamento é longo, complexo e confuso, como ilustra a imagem abaixo. Para algumas áreas terapêuticas, inclusive, a jornada não termina após o tratamento, mas reinicia, como um ciclo, retornando ao estágio de prevenção - como em infecções, para prevenir novo contágio, ou mesmo em cânceres, para buscar evitar uma recidiva.

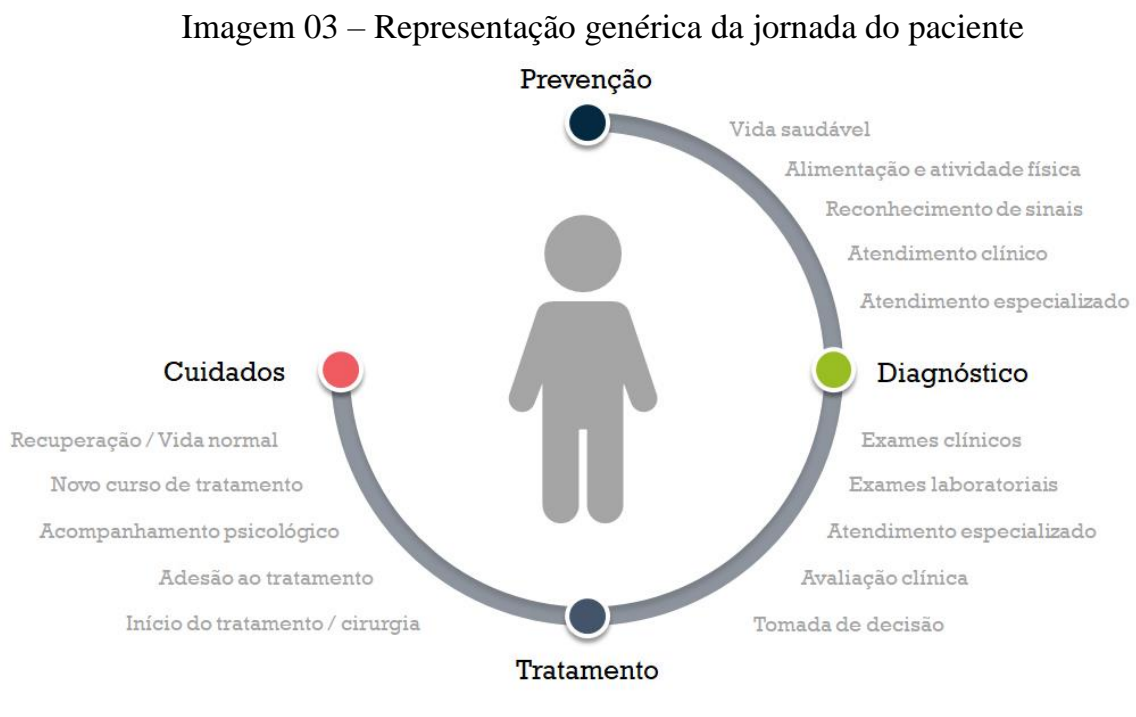

Fonte: Elaborado pelo autor

Na prática, isso significa que qualquer decisão de investimento por parte de governos e prestadores de serviço da saúde precisa considerar muitos fatores além do tratamento. A segurança e o equilíbrio da saúde para o conjunto da população passam pela análise de um conjunto de fatores para cada área terapêutica. Por exemplo: em um contexto de recursos escassos, o governo deveria investir em prevenção e vacinação, reduzindo eventualmente o número de infecções ou incorporar novos tratamentos e focar o montante disponível na compra de medicamentos?

Uma amostra desses direcionamentos é próprio comportamento recente da Conitec, como já comentado anteriormente. Neste ano, 12 incorporações (46\%) no rol de reembolsos do SUS foram referentes a métodos diagnósticos, cirúrgicos ou preventivos. Mesmo entre os medicamentos, três dos 14 incorporados foram ampliações de uso de drogas já reembolsadas pelo Ministério da Saúde. Mais que isso, em três dos seis casos em que a recomendação inicial negativa da Conitec foi revertida na decisão final, a intervenção da sociedade civil, por meio de 
associações de pacientes, foi fator decisivo - na jornada, o empoderamento dos pacientes, conceito reconhecido pela OMS, é parte das engrenagens que movem a decisão (ANWAR; CHOWDHRY; PRASAD, 2018).

As constantes mudanças na estrutura da sociedade demandam que o perfil de investimento e custeio do SUS seja continuamente revisto a fim de buscar sustentabilidade frente à alta complexidade de sua estrutura.

Trinta anos passados depois da promulgação da Constituição, o Brasil mudou de maneira significativa seu perfil demográfico e epidemiológico. Registrou tendências que, grosso modo, não deverão sofrer grandes transformações nos trinta anos subsequentes. ... Segundo as projeções do IBGE, a população de maiores de 65 anos triplica de 1988 para 2018, atingindo a cifra de 18,3 milhões, e chegará, em 2048, a 49 milhões de brasileiros, dos quais 14 milhões com mais de 80 anos. Essa tendência reflete um padrão de morbimortalidade no qual coexistem problemas decorrentes diretamente da pobreza associados a um quadro de predomínio das doenças crônico degenerativas, agravado por um elevado contingente de eventos provocados por causas externas. Isso acarreta mudanças no modelo de cuidados de atenção à saúde, no bojo de um processo em que as doenças agudas que podiam ser curadas são substituídas por outras que requerem cuidados continuados e permanentes (from cure to care apud Cochrane), que já se delinearam nos países desenvolvidos a partir de meados do século XX. Esse perfil obriga a intervenção de diferentes profissionais de saúde, bem como a prestação de serviços sociais e de apoio comunitário, assistência domiciliar, centros de cuidados prolongados e de cuidados paliativos. Como decorrência, os processos de referência e contrarreferência são continuados demandando alternativas aos recortes político-administrativos tradicionais, de modo a facilitar o fluxo da demanda. (NORONHA et al., 2018, p.2055)

A complexidade se agrava dada a complementaridade dos sistemas público e privado de saúde no Brasil. Muitas vezes, os pacientes transitam entre serviços públicos e privados, especialmente para determinados tipos de diagnóstico, ou para o uso de tratamentos de alto custo já incorporados pelo SUS, afetando o equilíbrio dos sistemas (SESTELO; DE SOUZA; BAHIA, 2013). Da mesma maneira, pacientes se deslocam regionalmente para ter acesso a serviços não disponíveis em seu local de residência. Assim, todos os agentes são, cada vez mais, chamados a contribuir com o balanço do sistema em toda a jornada do paciente.

\subsection{PROBLEMA DE PESQUISA}

No contexto de mercado descrito, há inúmeras perspectivas que podem ser avaliadas como um potencial problema de pesquisa para direcionar o estudo proposto. Seguindo a definição estabelecida por Moresi (2003), buscou-se estabelecer uma orientação para o estudo 
que fosse atual, relevante, viável e conectada à experiência profissional do autor. Para tanto, foi realizado estudo preliminar junto a fontes e dados secundários relativos ao mercado para estabelecer o problema de pesquisa proposto.

\subsubsection{Definição da questão de pesquisa}

Considerando os quatro pontos identificados anteriormente a partir do estudo preliminar, a saber:

- Mudanças no contexto estrutural e relação de forças entre os stakeholders no mercado, demandando alterações na estratégia de marketing, bem como na gestão de inovação;

- Novos parâmetros na relação comercial com prestadores de serviços de saúde, públicos e privados;

- Crescentes complexidade na jornada do paciente e necessidade de equilíbrio entre os diferentes estágios desta;

- Entrada de softwares e equipamentos digitais alterando a estrutura operacional do setor.

Adicionalmente, como colocado anteriormente na discussão de contextualização do mercado, criação de novas propriedades intelectuais são raramente conduzidas em solo brasileiro, sendo desenvolvidas nas matrizes, normalmente localizadas nos EUA ou Europa, e importadas pelas operações nacionais (BASTOS, 2005). Da mesma forma, empresas nacionais direcionam seus recursos para outro tipo de produto, focando na produção de genéricos e similares, bastante adaptados ao contexto do mercado local (DOS SANTOS; FERREIRA, 2012).

Isto posto, reconhece-se a necessidade de mudanças na estrutura de operação das indústrias farmacêuticas, em particular as que investem em criação de produtos e proteção da propriedade intelectual, para favorecer a inovação local além da molécula. Desta forma, para efeito deste projeto, temos, como problema geral de pesquisa a seguinte pergunta;

Quais oportunidades se abrem para a inovação além da molécula de forma que as empresas sejam bem-sucedidas no atual contexto da saúde no Brasil? 


\subsection{OBJETIVOS}

Considerando o cenário apresentado e o problema de pesquisa proposto, os objetivos deste projeto estão organizados como descrito a seguir.

\subsubsection{Objetivo principal}

O objetivo principal deste trabalho será identificar caminhos para inovação além da molécula no setor da saúde e observar de que maneira estes se contrapõem à tradicional gestão da inovação da indústria farmacêutica, focada no desenvolvimento e proteção de propriedades intelectuais.

\subsubsection{Objetivos secundários}

a. Identificação e análise de barreiras internas da indústria farmacêutica que afetam a tomada de decisão pelo investimento em inovação além da molécula;

b. Identificar processos de busca por novas oportunidades de inovação além da molécula oriundas da gestão estratégica dos stakeholders;

c. Observar boas práticas em inovação além da molécula a partir de modelos de interação de novos atores no setor brasileiro de saúde (healthtechs e biotechs).

\subsection{JUSTIFICATIVA}

\subsubsection{Relato da experiência}

A inspiração para a definição do tema desta pesquisa se origina no histórico profissional do autor, moldado no contexto de crescimento das tecnologias digitais e seus impactos nos 
meios de produção. Ainda durante a graduação em Jornalismo, teve a oportunidade de vivenciar, por meio da atuação em redações jornalísticas, como o surgimento das mídias digitais alterou profundamente todo o modo de produção e de geração de valor do segmento. Posteriormente, uma nova experiência no setor financeiro demonstrou que a velocidade das mudanças e a profundidade de seu impacto só crescia, levando a transformações não apenas na maneira de gerar valor para os clientes, mas até mesmo no arcabouço regulatório do setor, que precisou ser completamente redesenhado para abrigar o novo contexto de negócios.

Posteriormente, ao atuar como Gerente de Marketing Digital de uma grande indústria farmacêutica, encontrou um setor profundamente impactado por esses movimentos - e ainda buscando se posicionar nesse contexto de mudança. Em 2017, ao concluir especialização Lato Sensu em Marketing Digital, surgiram temas mais profundos para observação em relação ao impacto do avanço da tecnologia na realidade das empresas. Muitas delas, mesmo adeptas do uso de tecnologias em suas rotinas internas, demonstravam dificuldades em acompanhar o movimento transformacional dos mercados consumidores. Mais ainda, governos e entidades regulatórias demoram longos períodos para incorporar estas mudanças ao arcabouço legal, impedindo que os benefícios promovidos pela tecnologia cheguem aos pacientes - os principais interessados neste movimento dentro do segmento de saúde.

Assim, nasceu a principal motivação para este estudo, ou seja, a intenção do autor de compreender a dicotomia demonstrada na estrutura das indústrias farmacêuticas: por um lado, algumas das empresas que mais investem em inovação no mundo (PWC, 2018); por outro, preservam estruturas processuais tradicionalistas e conservadoras que se apegam à segurança de modelos consagrados, independendo se esses atendem à realidade do mundo atual.

Reconhece-se que o mercado busca se ajustar a esse contexto de mudanças, mas ainda tem dificuldade em gerenciar modelos práticos que auxiliem no desenvolvimento de inovação para modelos de negócio e também que ajudem a manter o grau de competitividade frente à competição de empresas normalmente ligadas a outros setores, como as chamadas medtech.

Assim, a intenção deste projeto, é realizar um estudo que colabora para a compreensão do segmento sobre como o atual contexto pode colaborar para o crescimento do negócio a partir de novos formatos de geração de valor para os clientes. Paralelamente, o autor espera, ainda, que este trabalho auxilie o setor a entender como melhor aproveitar oportunidades de desenvolvimento de produtos e serviços além da molécula que colaborem para a criação de valor em toda a cadeia - desde às próprias empresas até os pacientes, passando por pagadores 
e operadores dos serviços de saúde, auxiliando na ampliação da sustentabilidade do sistema de saúde no Brasil.

\subsubsection{Mercado e academia}

Vindo de sucessivos anos de crescimento e bons resultados financeiros, o mercado farmacêutico passa por uma fase de questionamento sobre seus próximos passos. Existem novos atores, como as operadoras verticalizadas, nova relação de forças, com papel relevante para os pagadores, e um novo contexto de saúde pública, como foco em prevenção e monitoramento de doenças raras e crônicas, que oneram o sistema como um todo.

Este projeto pode auxiliar no reposicionamento destas empresas a partir de um roadmap composto pela combinação entre transformação digital dos negócios e gestão estratégica dos stakeholders que levem seu caráter inovador dos laboratórios para os escritórios e para além das áreas de desenvolvimento de produtos.

Para a sociedade, também se trata de um tema relevante. Os próximos anos serão decisivos na maneira como a ciência clínica continuará se desenvolvendo para entregar à sociedade inovação nos tratamentos, mas também em temas complementares e fundamentais para o sistema - como reembolso, ou adesão aos tratamentos, por exemplo.

Por fim, para a academia, apresenta-se a possibilidade de estudo de um tema atual, ampliando os registros sobre transformação digital. Também contribuirá para a ampliação de conhecimento sobre um setor que não se abre muito para interação desta natureza, que é a indústria farmacêutica.

\subsection{ESTRUTURA DO TRABALHO}

Os desafios do segmento bem como as alternativas citadas serão descritas mais profundamente ao longo deste documento, de acordo com a estrutura apresentada a seguir:

- Capítulo 1 - Contexto e objetivos: apresentação da experiência do autor, da motivação e também do contexto do mercado farmacêutico, em particular das farmacêuticas que investem em criação de produtos e proteção da propriedade 
intelectual, que levou ao estudo do tema. Também descreve o desenvolvimento e descrição do problema de pesquisa a partir de levantamento inicial realizado a partir de dados secundários. Nesta seção também estão descritos os objetivos (geral e específicos) e a justificativa;

- Capítulo 2 - Referencial teórico: estruturação dos conceitos que serão utilizados na construção da pesquisa;

- Capítulo 3 - Metodologia de pesquisa: descrição da metodologia utilizada, apresentação das empresas estudadas, formato de coleta dos dados e análise dos dados gerados;

- Capítulo 4 - Resultados: descrição dos resultados obtidos, relatos e análise dos estudos de caso e análise comparativa entre a prática e a teoria;

- Capítulo 5 - Conclusões: apresentação das conclusões do estudo;

- Capítulo 6 - Contribuições e limitações: considerações sobre o alcance do estudo.

Por fim, serão apresentadas as referências bibliográficas e apêndices.

\section{REFERENCIAL TEÓRICO}

A análise do cenário da saúde, em especial sob a ótica da indústria farmacêutica, sugere uma tendência de saturação no modelo de lançamento subsequente de novos produtos em um ambiente com dificuldade de manter sustentabilidade em longo prazo. $\mathrm{O}$ direcionamento do investimento em inovação, nesse contexto, demanda uma ampliação da compreensão da relação entre diferentes stakeholders pelo segmento - não apenas sob uma perspectiva retrospectiva, mas, essencialmente, pela dinâmica em constante alteração.

Assim, a pesquisa aqui relatada se fundamenta em conceitos teóricos que serão desenvolvidos ao longo deste capítulo, a partir de revisão da literatura. Estes serão apresentados em três seções, descritas a seguir: 
- Inovação em grandes corporações, em especial na indústria farmacêutica: suas especificidades, fatores de influência e modelo de negócio baseado na proteção intelectual;

- Gestão estratégica de stakeholders: como o mapeamento e monitoramento dos grupos de interesse impacta a identificação de oportunidades de inovação e eventual redirecionamento da atuação no mercado;

- Digital Health e oportunidades além da molécula: de que maneira a transformação digital na saúde impacta os negócios na indústria farmacêutica e quais barreiras e oportunidades se apresentam para que o crescimento seja competitivo nesse contexto.

\subsection{INOVAÇÃO EM GRANDES CORPORAÇÕES}

Antes de discorrer sobre as mudanças que novos processos podem gerar na estrutura corporativa, se faz importante definir o conceito de inovação na indústria farmacêutica. Para tal, será feita uma distinção entre os diferentes tipos de inovação, considerando a perspectiva específica para o segmento. Inicialmente, é preciso ressaltar que o lançamento de produtos novos ou melhorados (novas indicações para medicamentos já aprovados, ou novas apresentações dos mesmos) é a base do comportamento mercadológico do setor, o que demanda um grande volume de recursos investidos em pesquisa e desenvolvimento (BASTOS, 2005). Paralelamente, o próprio sistema de registro de propriedade intelectual se configura como um instrumento de defesa para os segmentos de mercado conquistados (AKKARI et al., 2016), como se aprofundará a seguir.

O estudo da Inovação como tema da administração das empresas não é algo recente. Seu estabelecimento como diferencial competitivo para empresas - inclusive de diferentes portes - é tema recorrente, com modulações periódicas analisando diferentes segmentos e estruturas corporativas que impactam. Alguns autores divergem entre a definição de inovação e invenção, tratando-as como obras singulares da capacidade de criação humana, ou de atos isolados de mentes geniais.

Drucker (1987) questiona essa definição e ressalta a importância de se entender a inovação como um instrumento dos empreendedores, um recurso a ser compreendido e aplicado sistematicamente, inclusive sob a perspectiva de identificação de novas oportunidades. Em sua 
construção conceitual, trata a inovação como uma resposta estruturada a diferentes oportunidades que devem ser mapeadas e endereçadas pelos empreendedores. Kline e Rosenberg (1986) corroboram essa visão, ressaltando que, por definição, inovação é a criação e condução ao mercado de uma nova solução - o que traz incerteza para os empreendedores quanto ao resultado comercial de uma inovação.

Inovação não significa invenção. A invenção é o ato de gênio em criar um novo conceito para um novo dispositivo ou serviço potencialmente útil. Em inovação, isso é apenas o começo. Terminada a invenção, começa a segunda metade da inovação: transformar a nova ideia em um sucesso empresarial. Esta segunda etapa pode ser chamada de implementação, desenvolvimento comercial, criação de um novo empreendimento ou qualquer outro nome; é tão essencial para a inovação quanto pensar a ideia em primeiro lugar. (PINCHOT III, 1989, p.25).

Para parte das empresas, é nesta transição entre a ideia e a consolidação de um modelo de abordagem ao mercado que diversas falhas são cometidas. Mesmo com boas ideias, muitas vezes baseadas em necessidades claras de determinados grupos de clientes, as áreas de marketing, inovação ou outras áreas de suporte das indústrias farmacêuticas falham impiedosamente. Isso porque modelos institucionais de gerenciamento da inovação são tecnicamente e socialmente - instrumentos complexos de manejo (KLINE; ROSENBERG, 1986), especialmente quando são superficialmente implementados e não refletem o modelo estratégico, a estrutura institucional e a profundidade da cultura corporativa em que estão inseridos (SALEH; WANG, 1993; ENGEL, 2011).

Parte da complexidade deste movimento se origina no alinhamento entre cultura organizacional e estratégia de inovação. Essencialmente, são dois fatores que deveriam caminhar conjuntamente para o desenho de um modelo eficiente de gestão interna de inovação (SALEH; WANG, 1993; CHEN et al., 2018).

Uma estratégia, entretanto, não opera no vácuo. Deve haver um contexto estrutural correspondente visando manter o comportamento estratégico em níveis operacionais em linha com o comportamento pretendido da estratégia (SALEH; WANG, 1993, p.14).

Considerando o ponto de vista exposto, a estruturação de modelo de gestão interna da inovação assume uma função crítica no desenvolvimento do negócio em si, colaborando para um resultado sustentável em longo prazo. Saleh e Wang (1993) listam nove fatores ligados ao clima organizacional, estratégia empreendedora e estrutura corporativa que impactam diretamente o modelo de gestão da inovação em companhias. A imagem a seguir ilustra como esses elementos compõe a inovação no ambiente corporativo. 
Imagem 04 - Fatores que afetam a inovação no ambiente corporativo

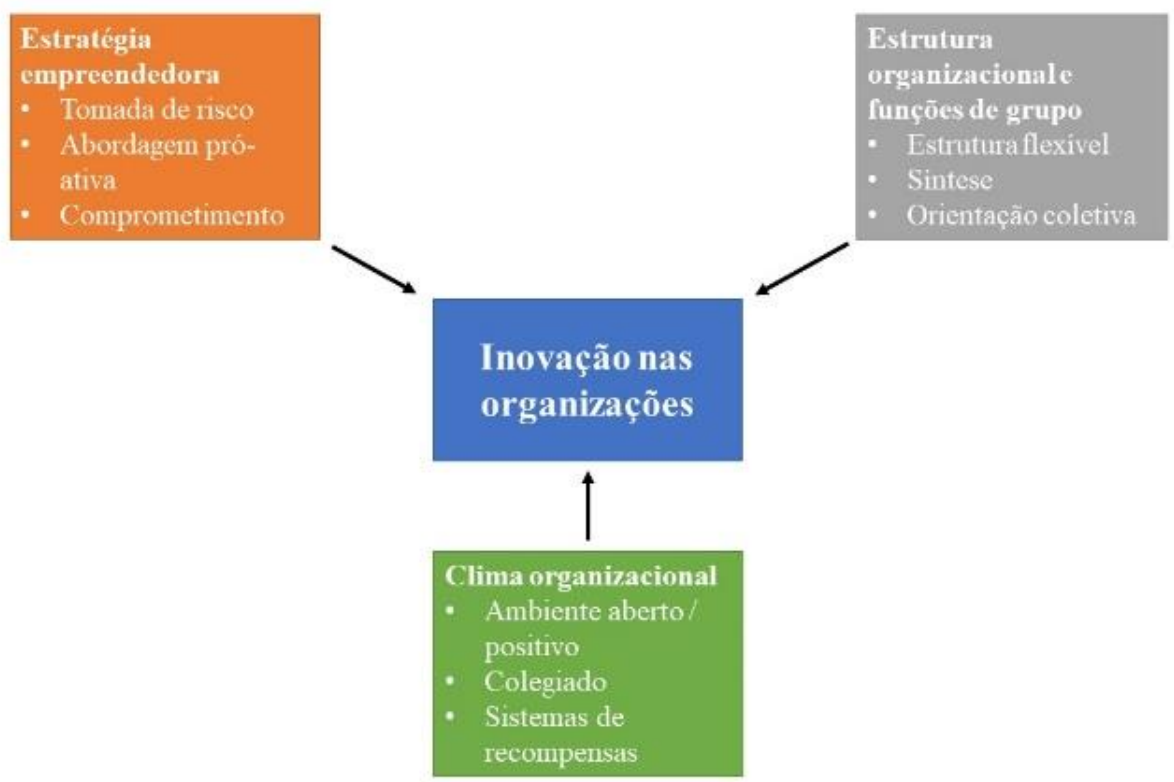

Fonte: SALEH; WANG, 1993

Em grandes empresas, coordenar estas três dimensões, além de potencializar o desempenho da inovação no ambiente corporativo, tem, ainda, o efeito de disseminar a cultura de inovação por toda a estrutura da companhia, evitando bolsões de inovação, exclusivamente referenciados nas áreas de P\&D (KRISHNA, 2018). A criação destes bolsões é parte da realidade vivida pelas indústrias farmacêuticas no Brasil quando se avalia a distância entre as práticas de pesquisa e desenvolvimento e os processos conduzidos pelas áreas de negócio e de suporte ao negócio (AKKARI et al., 2016), uma vez que toda a inovação emana das matrizes, delegando a operação local à repetição dos modelos existentes de abordagem aos mercados.

No caso de indústrias farmacêuticas que investem no em inovação radical, em especial de multinacionais, parte do gerenciamento dos fatores enumerados por Saleh e Wang (1993) não estão sequer disponíveis no processo de tomada de decisão das afiliadas. Processos como "tomada de risco", "estrutura flexível” e "sistema de recompensas" são dirigidos pelo desenho corporativo das matrizes. Assim, muitas vezes, o direcionamento da inovação passa pela resposta às necessidades e expectativas das matrizes e shareholders e não pela complexa realidade dos mercados locais - daí, por exemplo, a insistência no contínuo lançamento de medicamentos em países fechados para o reembolso dos tratamentos. 


\subsubsection{Inovação na indústria farmacêutica}

Para observadores externos, é difícil compreender eventuais críticas ao sistema de gestão da inovação na indústria farmacêutica. Em um mercado em que apenas um em cada 100.000 compostos efetivamente vira um medicamento, a um custo de pesquisas de US\$1,2 bilhão por droga, a cultura de inovação é uma característica fundamental (AKKARI et al., 2016; DIMASI; HANSEN; GRABOWSKI, 2003; FERREIRA et al., 2009). Junto com ela, características típicas que moldam o ambiente corporativo de forma positiva deveriam estar presentes: apetite a riscos, mapeamento constante do mercado, investimento constante em melhorias em produtos já lançados, resiliência estratégica e aprendizado com os erros.

Há, nessas empresas, no entanto, um distanciamento significativo entre a mentalidade dos laboratórios de pesquisa do setor e as áreas administrativas, inclusive no processo de definição da estratégia que levará o produto ao mercado. Na intrincada estrutura corporativa que sustenta o posicionamento das pesquisas como novos produtos ou produtos melhorados, cria-se uma "sub" cultura corporativa, que afasta iniciativas empreendedoras de criação de novos modelos de negócio ou novos processos para geração de valor para clientes, médicos e pacientes.

Um dos principais beneficiários da incapacidade de grandes organizações de implementar inovação é a comunidade de capital de risco. Há um padrão frequente no qual novas tecnologias interessantes são desenvolvidas em grandes empresas, mas sua implementação atola em um pântano de análises, aprovações e política. Quando essas oportunidades são rejeitadas por uma grande empresa, a insatisfação muitas vezes leva o aspirante a intraempreendedor ao empreendedorismo (PINCHOT III, 1989, p.26).

Em linhas gerais, o mercado farmacêutico não é visto como campo vasto para inovações em modelos de negócio, ou nas suas práticas comerciais. Pode-se perceber este movimento a partir de uma análise dos textos científicos que tratam do tema inovação nas indústrias farmacêuticas, uma vez que a maioria se refere a este tema apenas sob a ótica da pesquisa e desenvolvimento (como exemplos, AKKARI et al., 2016; BASTOS, 2005; DIMASI; HANSEN; GRABOWSKI, 2003; DOS SANTOS; FERREIRA, 2012; FERREIRA et al., 2009; LIMA et al., 2003).

Em um mercado altamente regulado, com estrito controle das atividades promocionais, bem como de atividades gerenciais, os modelos para lançamento e posicionamento de medicamentos no mercado se repetem seguidas vezes. Não é o tamanho da empresa ou o tipo 
de produto que opera que a impede de inovar, mas sim a dificuldade que tem para desafiar a atividade em funcionamento para encontrar novas maneiras de desenvolver a inovação (DRUCKER, 1987).

O empreendedor, por definição, transfere recursos de áreas de baixa produtividade e rendimento mais elevados. Naturalmente existem os riscos de o empreendedor não ser bem-sucedido. Porém, se ele pelo menos for moderadamente bem-sucedido, os retornos devem ser mais que suficientes para compensar qualquer risco que possa haver. Portanto, é de se esperar que o empreendimento seja uma atividade consideravelmente menos arriscada que a otimização. Realmente, nada pode ser tão arriscado quanto otimizar recursos em áreas onde o caminho apropriado e lucrativo é a inovação, isto é, onde as oportunidades para a inovação já existem. (DRUCKER, 1987, p.37)

Quando avaliando a definição de inovação da indústria farmacêutica para valoração dos avanços, Aronson, Ferner e Hughes (2012) detalham a perspectiva tradicional da indústria, reforçando os valores da inovação baseados no desenvolvimento de produtos. O trabalho reforça que a remuneração da inovação do setor virá a partir do desenvolvimento de novas drogas, a definição de novas utilidades para drogas existentes ou a melhoria das características atuais da droga - melhoria em segurança, eficácia, eficiência ou redução de efeitos adversos.

O sucesso duradouro, no entanto, resultou em um cenário que as coloca em conflito atualmente. Como já descrito anteriormente, os mercados estão mudando, os fatores de decisão por drogas também e mesmo a necessidade global de pesquisa por fármacos mudou, terminando com a era dos blockbusters e demandando investimento em mercados menores, como o de doenças raras (AKKARI et al., 2016). O que resultou em um cenário mais competitivo e custos ainda maiores para a criação de medicamentos.

\subsubsection{Proteção intelectual no setor farmacêutico}

A OMPI (Organização Mundial da Propriedade Intelectual), entidade internacional de Direito Internacional Público, integrante do Sistema das Nações Unidas, define Propriedade Intelectual como a soma dos direitos relativos às criações da mente: invenções, obras literárias e artísticas e símbolos, nomes, imagens e designs usados no comércio. Estes são divididos em duas categorias: propriedades industriais, que incluem patentes, marcas, designs industriais, entre outros; e copyright, que são direcionados a criações artísticas, como músicas, obras literárias, softwares e aplicativos e criações arquitetônicas (WIPO, 2020). 
No contexto corporativo, propriedades intelectuais garantem a concretização da invenção, por meio do registro de posse e uso dos conceitos criativos envolvidos na concepção de um produto, serviço, processo ou estrutura (GRZEGORCZYK, 2020). Prioritariamente, empresas buscam por direitos de proteção intelectual motivadas pela necessidade de resguardar tecnologias de produto e processo, criação de poder retaliatório e bloqueio de concorrentes (HOLGERSSON; GRANSTRAND, 2017). De acordo com a OMPI (2020), para a proteção de propriedades industriais, são utilizados quatro principais tipos de registro: Patentes, Desenhos industriais, Marcas Registradas e Indicações Geográficas.

É inegável o histórico de investimento em inovação por parte das indústrias farmacêuticas. Ao longo do século XX, especialmente, as empresas do segmento se consolidaram por sua posição de investimento contínuo em pesquisa e desenvolvimento. Esta característica colocou o setor entre os mais lucrativos - e provavelmente estáveis - da economia mundial. Com seus ganhos baseados no valor intangível de suas patentes e não apenas na tangibilidade dos produtos (comprimidos ou soluções, por exemplo), estas companhias têm uma das mais expressivas margens de lucro, o que também serve como proteção aos seus mercados. Grzegorczyk (2020) destaca que, entre empresas de grande porte, as patentes são o procedimento de proteção intelectual mais utilizado porque seu mecanismo de proteção internacional é o mais robusto, ao mesmo tempo em que tem maior impacto no resultado financeiro, por serem mais viáveis de consolidar em produtos e serviços.

Embora a construção de valor por meio de proteção intelectual não seja incomum em setores de desenvolvimento de alta tecnologia, ela é significativamente mais importante para a indústria farmacêutica que para outros segmentos (GRABOWSKI, 2002; JANNUZZI; VASCONCELLOS; DE SOUZA, 2008). A diferença, no entanto, está no impacto que os setores encaram essa relevância dentro do contexto de inovação. Enquanto outros setores (como semicondutores e computadores) entendem que temas como tempo de chegada ao mercado, qualidade do serviço e superioridade do produto compõem um pacote de diferenciais relevantes para a inovação, a indústria farmacêutica valoriza, prioritariamente, o registro e proteção da patente como fator mais importante da inovação (GRABOWSKI, 2002).

Como explicado anteriormente, isso se dá pelo foco prioritário da inovação de produtos - no caso da indústria farmacêutica, de alto custo e elevado risco. Sem uma proteção sólida, o lançamento de um novo fármaco seria seguido, logo após a aprovação por uma entidade regulatória, de uma cópia, que reproduziria os efeitos do produto original, sem passar pelo longo período de desenvolvimento. Assim, a proteção de 20 anos, padrão concedido pela FDA, 
garantiria um prazo para recuperação dos investimentos despendidos na criação de uma nova molécula. Historicamente, foi assim que se desenvolveu a lucratividade do segmento.

Nas últimas décadas, no entanto, mesmo essa perspectiva tem passado por mudanças. Primeiro, pelo aumento de competitividade entre as próprias indústrias farmacêuticas. Ainda que não possam replicar as drogas desenvolvidas por concorrentes, as empresas do setor desenvolvem pesquisas em campos semelhantes, aproximando bastante a abordagem do mecanismo de ação, ainda que para drogas distintas. Com isso, a maioria das indústrias passou a antecipar o registro de proteção de suas patentes para a fase pré-clínica dos estudos, muito anterior à sua aprovação e consequente lançamento (GRABOWSKI, 2002). Da mesma forma, o crescimento do investimento em P\&D em países emergentes (especialmente China, Coreia do Sul e Índia) aumentou a exigência pelo registro internacional das patentes, elevando o custo em uma fase ainda de desenvolvimento do produto (LAURENS; LE BAS; SCHOEN, 2019). Com isso, a estimativa de vida útil de patente caiu em cerca de $40 \%$, reduzindo-a a 12 anos (GRABOWSKI, 2002).

Adicionalmente, como contextualizado anteriormente, cresceu a pressão por acesso aos medicamentos - de maneira mais direta, melhores negociações por preço. A aprovação regulatória de uma droga em determinado mercado não garante sua venda. Na maioria dos países, após a autorização de comercialização inicia-se o processo de aprovação de reembolso. Especialmente no caso de medicamentos de alto custo, somente com o reembolso institucionalizado (pelo governo ou por meio de planos de saúde privados), é que se pode massificar a utilização do fármaco, concluindo então, o ciclo descrito inicialmente, com a comercialização no período de proteção da patente compensando o investimento feito durante sua pesquisa - incluindo aí a internacionalização da proteção e aprovação e reembolso em diferentes mercados (LAURENS; LE BAS; SCHOEN, 2019). No Brasil, o processo de incorporação de um medicamento ao rol de reembolso do SUS, por meio da Conitec, pode levar até dois anos após a aprovação regulatória - sem a garantia de que, na verdade, será incorporado.

Por fim, a questão do acesso demonstra a crescente preocupação dos governos com a sustentabilidade e equilíbrio dos sistemas públicos de saúde. Assim, ao mesmo tempo em que a proteção intelectual teve um papel importante no desenvolvimento de tratamentos para doenças cardiovasculares, câncer e AIDS, os governos também buscaram encontrar soluções para acelerar o acesso por meio do incentivo aos medicamentos genéricos e biossimilares (GRABOWSKI, 2002). Foi o caso da política de genéricos no Brasil, na segunda metade dos 
anos 90. Por meio de intervenções diretas no mercado, o governo quebrou patentes vigentes, mudou a regulamentação para comercialização e ampliou o auxílio a empresas locais para que desenvolvessem tecnologia de desenvolvimento de medicamentos genéricos (QUENTAL et al., 2007).

Embora a estratégia também tivesse por objetivo fortalecer o desenvolvimento de tecnologia local, acabou por afastar os laboratórios de $\mathrm{P} \& \mathrm{D}$ do país. Isso porque as farmacêuticas que investem na criação de propriedades optaram por se concentrar em países com maior proteção intelectual (reforçando especialmente as matrizes na Europa e nos EUA), enquanto a indústria brasileira optou por investir no desenvolvimento de processos de manufatura de medicamentos genéricos (QUENTAL et al., 2007).

Isso resultou em "dois tipos de empresas com competências tecnológicas e estratégias competitivas distintas: um núcleo de grandes farmacêuticas gerando novos medicamentos e um grupo de imitadores que dependem de imitações incrementais, obtendo licenças do grupo principal ou fabricando medicamentos genéricos". (apud Bottazzi et al., 2001). Enquanto o último grupo depende do mercado interno protegido ou, em países com controle de preços de medicamentos ou baixa proteção de proteção intelectual (baixos incentivos para inovação), com medicamentos me-too (mercados enormes como o mercado de medicamentos genéricos); o primeiro grupo das empresas racionalizaram seus recursos, estabeleceram redes com parceiros externos, se apropriaram de conhecimentos e recursos externos por meio de aquisições ou colaborações com empresas de biotecnologia ou laboratórios públicos e aumentaram sua taxa de fusões e aquisições para fortalecer e expandir seus mercados (LAURENS; LE BAS; SCHOEN, 2019)

Naturalmente, embora seja considerado um dos mais significativos, o caso brasileiro não é o único. Diversos outros países seguiram por esse mesmo caminho, priorizando a lista de medicamentos considerados essenciais pela OMS - em determinado momento, 90\% desta lista foi composta por medicamentos sem proteção de patentes e de baixo custo. Como resultado, os genéricos cresceram significativamente no mercado, impactando a posição dos medicamentos de referência. A imagem a seguir ilustra o cenário evolutivo dos genéricos no início dos anos 2000, demonstrando o impacto após as mudanças vivenciadas na segunda metade dos anos 90 (QUENTAL et al., 2007). 
Imagem 05 - Evolução da participação dos medicamentos genéricos 2001/2005 (em MM US\$)

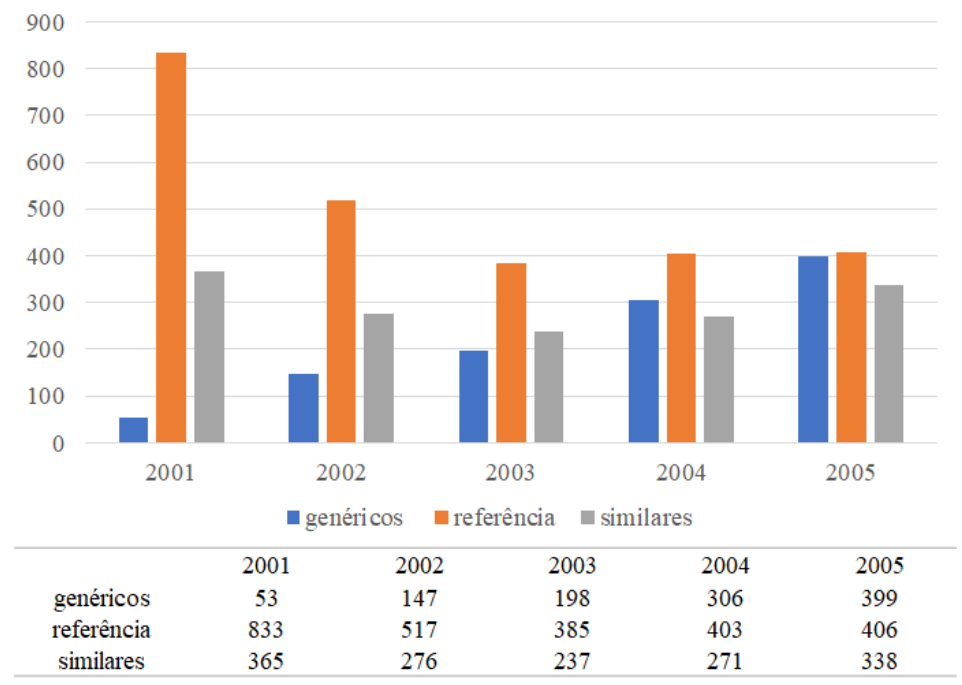

Fonte: IMS apud QUENTAL et al., 2007

Não significa, no entanto, que o cenário apresentado reduz a importância da proteção intelectual para as indústrias farmacêuticas. Demanda, porém, uma mudança estratégica. Em um contexto que demanda aumento no investimento, um ambiente mais competitivo, com menor proteção da patente, menor vida útil da propriedade intelectual e menos garantia de retorno, a busca por criação de novas propriedades, ou extensão da vida útil das mesmas, não é a única alternativa.

\subsubsection{Inovação "além da molécula"}

O contexto do segmento da saúde mostra um ambiente em plena transformação, afeito a empresas capazes de se adaptar continuamente. A persistir o crescimento das soluções digitais no tratamento à saúde, um caminho que se apresenta à indústria farmacêutica é ampliar sua capacidade de compreender a jornada do paciente e estender seu leque de soluções para uma abordagem holística da saúde, não apenas na criação de medicamentos. Anwar, Chowdhry e Prasad (2018) defendem que essa mudança não significará um abandono completo dos modelos de criação de moléculas e proteção da propriedade intelectual, mas uma migração para uma abordagem inteligente, capaz de prever os movimentos disruptivos seguintes, e que ofereça sugestões para adaptação e mudanças nos modelos existentes.

A chamada inovação "além da molécula" é o direcionamento dos esforços de inovação para além do desenvolvimento de produtos. Não significa, nesse caso, abandonar a criação de 
novos fármacos, mas, sim, redirecionar recursos que permitam desenvolver novos produtos e serviços que auxiliem na adaptação ao ambiente em constante transformação no qual estão inseridas as indústrias farmacêuticas.

O cenário incerto e com custos e riscos elevados, inseriu as farmacêuticas em um contexto de investimento em inovação muito mais focado na progressão de suas medicações, maximizando os ganhos já conquistados (AKKARI et al., 2016). Historicamente, isso representava um ciclo que não se interrompia. Um novo medicamento bem sucedido e aceito garantia remuneração e elevadas margens enquanto durasse a proteção da sua patente. Enquanto isso, a indústria proprietária se preparava para um novo produto - e, portanto, um novo registro, que garantiria os resultados pelo período subsequente ao fim da patente anterior.

Estrutura-se, sob essa perspectiva, o que Espedal (2002) e Kauffman (2004) se referem como a "armadilha do sucesso", uma sequência em que as empresas repetem, continuamente, decisões tomadas anteriormente e que as conduziram a um cenário positivo, mas que as impedem de se adaptar e ajustar a novos contextos. Um modelo de estruturação cultural que silencia vozes divergentes e constantemente aproxima novas iniciativas dos processos operacionais já estabelecidos e corporativamente reconhecidos, impedindo, inclusive, o avanço da aprendizagem corporativa (ESPEDAL, 2002).

Organizações e indivíduos podem ficar excessivamente confiantes de que possuem as habilidades para lidar com os problemas que enfrentam desde que suas experiências anteriores sejam bem-sucedidas. Isso pode, no entanto, não ser o caso se estivermos falando sobre domínios de ação significativamente diferentes, ou quando a relação entre o sucesso anterior e o desempenho futuro for incerta (por exemplo, um desastre nuclear ou grande descoberta científica). Mas, enquanto a confiança aumentar, as organizações tenderão a não descobrir e aprender com uma série de falhas imprevistas enquanto estas parecerem insignificantes. (ESPEDAL, 2002, p. 6).

Para as indústrias farmacêuticas, em geral, essa armadilha significa o investimento exclusivo na criação ou melhoria de novos medicamentos, sob a mesma estrutura de organização e abordagem ao mercado. Ignoram, desta forma, que a inovação se estende em diferentes dimensões, que são complementares: produto, processo, marketing e organização (OCDE, 2005). Não reestruturam suas organizações internas, limitando-se a repetir modelos previamente bem-sucedidos, enfraquecendo, sucessivamente, estes mesmos modelos. Mesmo quando o fazem, e há relatos de casos de investimentos em aplicativos de suporte ao diagnóstico baseados em inteligência artificial, por exemplo, as indústrias farmacêuticas buscam definir os mesmos processos e critérios de avaliação de risco, sem adaptações consistentes na maneira como conduzem P\&D para seus fármacos (SCHUHMACHER et al., 2020). 
As inovações que abrangem mais de um tipo, tais com as que incluem um componente de processo e um organizacional, podem exercer um papel crescentemente importante na competitividade da empresa em seus ganhos de produtividade. Por exemplo, uma reestruturação das operações de produção poderia envolver inovações de processo, organizacionais e de marketing; inovações de marketing e organizacionais poderiam ser implementadas visando tirar melhor proveito de uma inovação de produto (OCDE, 2005, p. 73).

Trapp, Voigt e Brem (2018) reconhecem que inovações para além da pesquisa e desenvolvimento, que impactem todo o modelo de negócios e não apenas a linha de produtos são essencialmente mais difíceis, especialmente para empresas com modelos consolidados. No modelo descrito por Trapp, Voigt e Brem (2018), considera-se inovação no modelo de negócios se a empresa consegue, de maneira bem-sucedida, implementar uma nova proposta de valor (que pode ser uma evolução na linha de produtos que leve à nova percepção de valor pelos clientes) e também uma nova constelação de valor, envolvendo processos e estrutura corporativa.

Somente neste contexto os gerentes de empresas estabelecidas seriam obrigados a adotar uma nova estrutura cognitiva ou lógica central para a criação e captura de valor. A ideia inicial de inovação, no entanto, pode ter como alvo apenas um desses dois componentes principais do modelo de negócios, mas, com o tempo, as mudanças em ambos os componentes devem ser perceptíveis. Além disso, a ênfase em apenas um desses dois componentes do modelo de negócios confunde a delimitação entre Inovação do Modelo de Negócios e inovação de produto ou processo (TRAPP; VOIGT; BREM, 2018, p. 08).

Por fim, a estruturação de novas linhas de receita - seja por meio de iniciativas que alavanquem o portfólio atual, ou da criação de novos produtos e serviços não medicamentosos - fica sujeita à disposição das pessoas em confrontar uma cultura corporativa que valoriza a repetição e não a tomada de riscos. Em um mercado que passa por uma turbulenta transformação e reorganização de forças, a perspectiva de conflito entre interesses internos e externos se mostra como uma ameaça crescente.

\subsection{GESTÃO DOS STAKEHOLDERS}

Como descrito anteriormente, o cenário da saúde no Brasil tem se tornado progressivamente mais complexo para indústrias farmacêuticas. Além das constantes mudanças próprias do momento, há também o questionamento direto quanto ao custo dos tratamentos e o valor do sucessivo lançamento de novas moléculas. Governos e agentes da saúde privada 
(seguradoras, planos de saúde, hospitais) olham para a sustentabilidade dos seus serviços em longo prazo, demandando, assim, articulação contínua entre as diferentes esferas, ainda que, muitas vezes, as perspectivas sejam conflitantes (SESTELO; DE SOUZA; BAHIA, 2013). Em um momento como a pandemia de COVID-19, os diversos modelos de PPP (Parceria Público Privada) entre agentes públicos e privados foram de extrema relevância para manter o sistema de saúde operacional, como por exemplo na construção e gestão de hospitais de campanha para auxílio emergencial.

Essa complexidade multidimensional no sistema coloca as indústrias farmacêuticas sob pressão em relação a sua postura tradicional. O número de agentes interessados aumentou e seus interesses são bastante amplos. Consideram, sim, os fatores econômicos envolvidos na manutenção da sustentabilidade do sistema, mas também se atentam para o contexto social que envolve as tomadas de decisão. Posto que todas as decisões de negócio têm implicações éticas e sociais (FREEMAN et al., 2010), as empresas devem partir de um ponto de vista integrador, conciliando interesses dos diferentes stakeholders, e não isolando-os.

Dada a turbulência que as corporações enfrentam atualmente e a própria natureza do ambiente externo, consistindo em aspectos econômicos e forças sócio-políticas, há uma necessidade de Schemata conceitual que analise essas forças de uma forma integrativa. Precisamos entender as complexas interconexões entre forças econômicas e sociais. Isolando "questões sociais" separadas do impacto econômico que têm, e por outro lado, isolar questões econômicas como se não tivessem efeito social, erra o alvo tanto gerencial quanto intelectualmente. Ações voltadas para um lado não abordarão as preocupações do outro. Processos, técnicas e teorias que não consideram todas essas forças não conseguirão descrever e prever o mundo dos negócios como ele realmente é. (FREEMAN, 2010, p. 40)

Emanuel (1999) destaca que, no contexto de saúde, a relação entre os diferentes stakeholders é, em geral, conflituosa e divergente. Embora o interesse de todos seja garantir serviços de saúde de alta qualidade, é uma possibilidade pequena, justamente pelos eventuais conflitos de interesse dos agentes e de seus representantes. Para Emanuel (1999), a solução, nesse caso seria a substituição, pelas empresas do segmento, de uma abordagem focada nos resultados econômicos para os shareholders, pelo enfoque em criação de valor total para o sistema, permitindo que pacientes e demais agentes também sejam cobertos pelos benefícios sociais do modelo.

Apresenta-se, portanto, a necessidade de um modelo de gestão que considere a criação de valor compartilhado entre os diferentes stakeholders da saúde para a sustentabilidade do sistema. Em um segmento em que os diferentes agentes estão progressivamente mais 
conectados, a operação que tenta se impor aos interesses do conjunto tende a ampliar a desconfiança no setor - além de limitar os resultados alcançados (FREEMAN et al., 2018). No contexto da saúde, especificamente no que diz respeito à indústria farmacêutica, ainda prevalece o modelo de imposição das novas moléculas, sem a ampliação da compreensão do valor para as diferentes partes.

Em um cenário de constante mudança, Freeman et al. (2018) defendem que este processo de co-criação de valor precisa considerar o contexto atual para todos, mas também antecipar o que será importante para novos ciclos de geração de valor - aumentando o valor do bolo para o conjunto de stakeholders e não apenas dividindo a parte de cada um no montante atual. Assim, a gestão estratégica dos stakeholders passa pela compreensão do papel de cada um no sistema e abertura para compartilhamento de informações, que serão fundamentais para alavancar a contínua expansão do valor gerado pela empresa (FREEMAN, 2010; FREEMAN et al., 2018).

Para criar valor, as empresas precisam ver o mundo através dos olhos de seus múltiplos stakeholders e ser capazes de aproveitar não apenas os recursos que eles controlam, mas também as informações e percepções que esses stakeholders podem fornecer. Essas percepções e informações permitirão que as empresas encontrem novas maneiras de criar valor e aumentar o bolo de valor para todos compartilharem. De certa forma, pode-se dizer que um aspecto importante da abordagem das partes interessadas é a ênfase nessa empatia que permite às empresas um contato próximo com suas partes interessadas e permite que aproveitem seus insights, know-how e informações, o que as ajuda a evitar preso em uma mentalidade de "esta é a maneira que sempre fizemos" (FREEMAN et al., 2018)

Um exemplo nesse contexto é o caso da incorporação do medicamento Spinraza (Nusinersena) ao rol de medicamentos reembolsados pelo SUS. Utilizado para o tratamento de Atrofia Muscular Espinhal 5q, é o medicamento mais caro já incorporado ao rol do SUS, ao preço de R $\$ 255.614,88$ por frasco (valores de dezembro de 2020$)^{9}$. O processo é reconhecido por todos os stakeholders do setor - governo, prestadores de serviço (hospitais e clínicas), associações de pacientes, shareholders - como uma abordagem diferenciada no processo de obtenção de garantia de cobertura pela indústria farmacêutica. Após uma primeira recusa por parte da Conitec, a Biogen, empresa proprietária da molécula, submeteu novamente o medicamento para análise de incorporação, mas considerando um modelo de compartilhamento de risco, em que o

\footnotetext{
${ }^{9}$ Preço máximo de Venda ao Governo (PMVG), sem ICMS, definido pela Câmara de Regulação (CMED), para o frasco ampola 5mL, 2,4mg/mL (ANVISA, 2020).
} 
governo remunera o laboratório apenas em caso de melhora do paciente. Depois de meses de negociações e discussões sobre o modelo de avaliação, a Conitec decidiu recomendar a incorporação do Spinraza, em março de 2019, mesmo considerando o elevado custo de aproximadamente $\mathrm{R} \$ 1,5$ milhão por paciente no primeiro ano de tratamento. O processo gerou a seguinte manifestação pública de Renato Alencar Porto, então diretor de Regulação Sanitária da Anvisa.

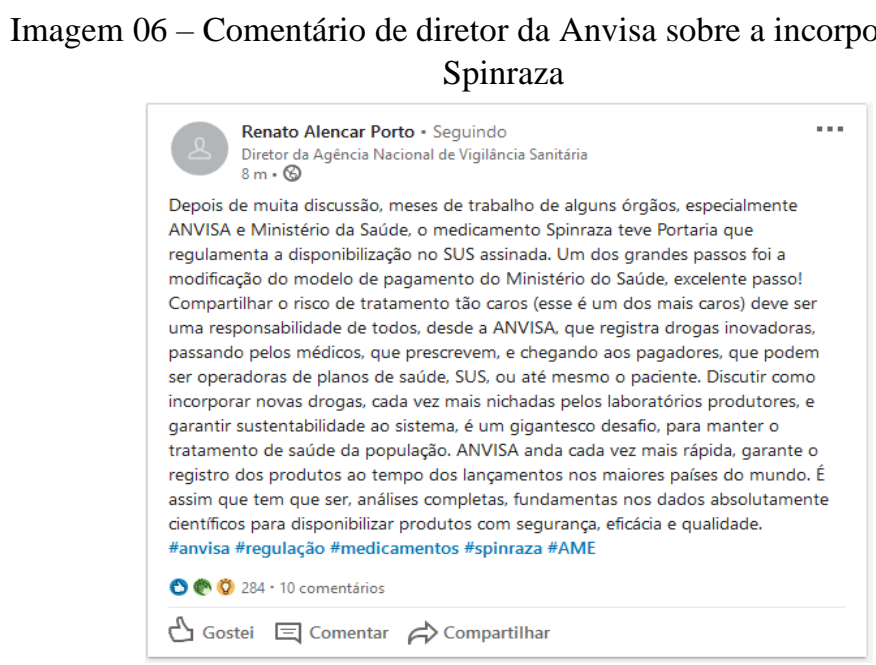

Fonte: Reprodução LinkedIn

Pode-se discutir se é apropriada ou não a manifestação pública de um diretor de uma agência governamental, mas o reconhecimento ilustra o tema da criação de valor compartilhado pela empresa para todos os stakeholders envolvidos. A abertura ao risco agiu a favor da empresa junto ao sistema, que reconheceu a iniciativa, permitindo o reembolso do medicamento, prevendo a sustentabilidade do SUS e o acesso dos pacientes ao melhor tratamento. Como definem Freeman et al. (2010), sucesso na busca pelo alinhamento na entre os interesses dos diversos stakeholders, ao invés de fomentar o conflito entre eles. Como comentado anteriormente, essa abertura ao risco, no entanto, não é o padrão atual da indústria farmacêutica. Nenhuma das solicitações de análise de incorporação à Conitec submetidas em 2020 prevê, formalmente, mecanismos de compartilhamento de risco entre a indústria e o SUS.

\subsubsection{Representatividade dos stakeholders}

Considerando o processo de criação de valor compartilhado conforme descrito, a empresa precisa, portanto, definir estratégias de acompanhamento e gerenciamento dos 
stakeholders. Por meio destes processos, amplia a compreensão do valor que determinado grupo de interesse tem para suas atividades, como pode contribuir para ampliação do valor total e de que maneira pode abordar estes, prevendo alterações em seu comportamento (FREEMAN et al, 2018).

Para a indústria farmacêutica, em particular as que atualmente já investem no desenvolvimento de novos medicamentos, conciliar o interesse dos diferentes stakeholders significa revisar alguns princípios fundamentais, como o modelo de inovação baseado na criação e proteção da propriedade intelectual. Não significa abrir mão das referências econômicas no desenvolvimento de novos produtos, mas, essencialmente, considerar interesses de grupos de stakeholders até então negligenciados, mas que crescem em poder. Ressalte-se que, como destacado por Emanuel (1999), o fato de que o ambiente da saúde nem sempre conta com representatividade clara dos agentes faz com que a interação com eles seja limitada.

Um exemplo é a relação com as associações de pacientes, que representam pacientes (e, portanto, consumidores) de determinadas áreas terapêuticas. Embora a relação com estes seja limitada por fatores regulatórios, é notório que estes grupos têm crescido em representatividade no ambiente da saúde, chegando a influenciar processos de incorporação de medicamentos no SUS, como demonstra a análise das decisões da Conitec. Assim, considerando as relações dentro do segmento, pode-se identificar o seguinte:

Imagem 07 - Indústria farmacêutica e stakeholders primários

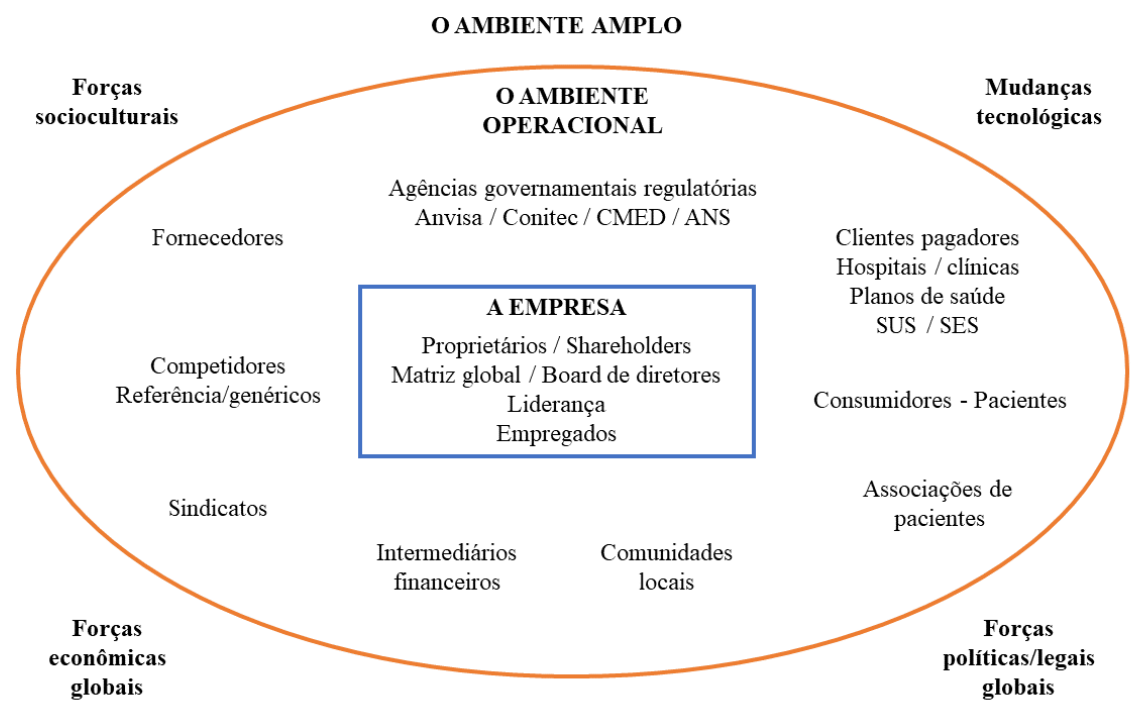

Fonte: Elaborado pelo autor a partir de modelo proposto por Harrison e John, apud Freeman et al. (2010) 
A especificidade do mercado brasileiro também faz com que o nível de complexidade seja maior. Com alta representatividade tanto do setor público quanto do privado, os processos de incorporação e reembolso de medicamentos precisam ser conduzidos para os dois setores, com burocracias distintas e que se influenciam mutuamente. Da mesma forma, não é incomum no sistema brasileiro - em especial para tratamentos de alta complexidade e alto custo - que os pacientes transitem entre os dois setores para ter uma solução completa, ou um diagnóstico detalhado.

Assim, se torna ainda mais relevante que a empresa tenha uma reputação reconhecida por todos os grupos de interesse (FREEMAN et al., 2010; FREEMAN et al., 2018). Quanto maior a capacidade de transitar entre diferentes grupos, compreender sua capacidade de organização e representatividade e colaboração, mais será o potencial de geração de valor compartilhado pela empresa em saúde, dada a complexidade do segmento (EMANUEL, 1999). Assim que o esse crescimento de potencial é percebido, aumenta a atratividade da empresa para os stakeholders, resultando em um ciclo virtuoso de geração de valor para a corporação.

Alguns dos benefícios de fomentar relacionamentos de confiança, respeito e
mutuamente benéficos com as partes interessadas incluem uma excelente
reputação e a capacidade de atrair um maior número de partes interessadas
que criam valor para a empresa porque é muito atraente trabalhar com ela e,
portanto, a capacidade de obter melhores recursos, especialmente informações
valiosas (Barringer e Harrison, 2000; Freeman et al., 2010; Harrison et al.,
2010). Esses benefícios resultam em uma capacidade aprimorada de
planejamento e um nível mais alto de flexibilidade estratégica, pois a empresa
pode obter mais facilmente o que precisa de uma gama mais ampla de
interessados em potencial (Freeman e Evan, 1990). Em termos de valor criado,
além de todo o valor não econômico descrito nesta seção, a empresa tende a
ser mais eficiente por causa dos esforços adicionais de suas partes interessadas
e mais inovadora por causa das informações valiosas que recebe deles
(FREEMAN et al., 2018)

Para as indústrias farmacêuticas, este campo para ampliação de valor pode ser uma visão holística sobre a jornada do paciente, ou seja, o processo pelo qual este vai da condição de prevenção até a gestão do tratamento. Por meio de inovações que estejam para além do desenvolvimento de novas moléculas e, por conseguinte, de novas propriedades intelectuais, a indústria pode se posicionar como um parceiro que contribui efetivamente para geração de riqueza no segmento, se aproximando dos diferentes stakeholders - inclusive dos que hoje é afastada - e abrindo as portas para um ciclo virtuoso de inovação conjunta. 


\subsubsection{Pressão dos stakeholders internos}

Freeman (2004) defende que um dos mais importantes erros de interpretação da teoria dos stakeholders é a conclusão de que, no princípio do constructo, "há um conflito entre shareholders e os demais stakeholders". Segundo o autor, a própria afirmação contém um erro conceitual, uma vez que não considera shareholders como parte do grupo de stakeholders da empresa e, portanto, um grupo que deve ser gerenciado para que seus interesses se alinhem na direção geral que a abordagem estratégica determina.

Para a indústria farmacêutica, a ausência de estratégias claras para gerenciamento dos diferentes stakeholders resulta efetivamente no problema citado por Freeman (2004) - conflito resultante entre os interesses econômicos de curto prazo e novos modelos de inovação que cubram diferentes perspectivas dos grupos de interesse. O conflito não é, portanto, próprio da teoria, mas sim de como as lideranças conduzem essa abordagem. Na definição de investimentos em inovações além da molécula, pesam as dificuldades que as empresas do setor têm com o tema da transformação digital e a demonstração de valor dessas iniciativas (HERRMANN et al., 2018), o que resulta em estratégias conflitantes para diferentes grupos de stakeholders (FREEMAN et al., 2018).

No entanto, acreditamos que uma empresa que constantemente troca os interesses de um grupo contra outro está se preparando para problemas e possivelmente até mesmo para o fracasso a longo prazo. Muitas vezes, as perguntas erradas estão sendo feitas: "Por que não cortar um pouco os benefícios dos funcionários para que possamos investir em um novo sistema de estoque?" ou "Como podemos reduzir os custos de materiais (o que pode reduzir a qualidade do produto) para que possamos aumentar os lucros e dividendos?" Em vez desse tipo de pergunta, sugerimos algo como: "Como podemos reestruturar a forma como gerenciamos o relacionamento com os funcionários para que eles sejam mais felizes e produtivos, resultando em maior lucratividade e na capacidade de pagar mais dividendos? (FREEMAN et al., 2018)

\subsection{DIGITAL HEALTH E OPORTUNIDADES ALÉM DA MOLÉCULA}

Para tornar ainda mais complexo o cenário de mudanças no setor de saúde que impacta as indústrias farmacêuticas, em especial as que investem no desenvolvimento de produtos, a velocidade das transformações é progressivamente maior. Por meio da intensa digitalização do segmento, mudanças de comportamento dos consumidores, e mesmo nas abordagens 
terapêuticas adotadas pelos profissionais, são cada vez mais constantes. Soluções digitais fazem parte da jornada integral do paciente - desde soluções para prevenção e detecção precoce de tendências genéticas a determinadas doenças até aplicações focadas em suportar e garantir adesão aos tratamentos. Até mesmo a produção de medicamentos será impactada por esses movimentos.

A engenharia genética é outra área que já está criando rupturas na indústria farmacêutica, pois muitas empresas fornecem dados às pessoas sobre seus genes. As pessoas agora podem se familiarizar facilmente com sua genética, defeitos metabólicos e aceitação de diferentes doenças. Além disso, a impressão 3D está transformando a indústria de manufatura e já causando um grande impacto na indústria de eletrônicos para companhias aéreas. As impressoras 3D estão sendo adotadas na indústria farmacêutica e farão medicamentos sob demanda e direcionados. Isso também dará uma chance a novos inovadores e pequenas empresas de vir e praticar suas ideias. A empresa farmacêutica Aprecia já aprovou um medicamento impresso em 3D chamado Spritam, que está sendo usado na epilepsia (ANWAR; CHOWDHRY; PRASAD, 2018, p. 78)

Herrmann et al. (2018) destacam que a transformação digital da saúde é uma oportunidade para acelerar a performance do segmento, por meio do aumento da qualidade dos serviços e da redução dos custos. Destacam, no entanto, que os modelos de negócio precisarão ser transformados, por meio da colaboração entre os diferentes atores do mercado - grandes empresas, consolidadas, com a profunda compreensão do ambiente regulatório, e startups, ágeis e com capacidade para criar rupturas nos modelos de inovação do segmento.

Promover mudanças nas estruturas tradicionais da empresa também é a abordagem que se propõe para o debate em torno da transformação digital. Rogers (2017) destaca que, ao contrário do que muitas empresas têm interpretado recentemente, transformação digital é um tema cultural e estratégico, que pode ser ponto de virada para empresas tradicionais que pretendem manter ou ampliar uma posição de liderança em determinado mercado.

Quais serão, nesse cenário, as competências que irão diferenciar as empresas líderes do novo mercado?

Estar em posição de se adaptar rapidamente quando um modelo de negócios disruptivo surgir será a chave para as receitas futuras. Uma ameaça disruptiva para as indústrias de ciências biológicas e as start-ups é o forte foco das corporações de tecnologia para estabelecer modelos de plataforma de negócios e assumir o poder de barganha necessário para se apropriar do valor criado. Resta saber se os futuros líderes de mercado de um setor de saúde transformado serão as corporações existentes e os atuais líderes de mercado ou novos jogadores que emergirão das fileiras das start-ups de hoje (HERRMANN et al., 2018, p. 06) 


\subsubsection{Modelo de identificação de oportunidades de inovação}

A questão, como descrita anteriormente, é que o mercado passa por uma das maiores transformações que já testemunhou; a ciência avança a passos muitos rápidos; a estrutura dos clientes mudou, alterando a relação de forças; o número de competidores cresceu sensivelmente. No contexto atual, os fatores impulsionadores da inovação corporativa mudaram, demandando um novo comportamento. Analisando o cenário de tomadas de decisão empreendedoras, Drucker (1987) apresenta sete fontes de oportunidades inovadoras que servem como fatores de mudança impulsionadores da inovação para as empresas.

- O inesperado: eventos não esperados, ondas de sucesso ou fracasso oriundas de movimentos não mapeados que abrem porta para reposicionamento e inovações;

- Incongruências: discrepâncias entre movimentos previstos no planejamento e que se mostram diferentes na realidade e dão origem a movimentos inovadores em resposta a essas diferenças;

- Necessidade de processo: quando a oportunidade de inovação vem da "obrigação" de responder internamente a um movimento para inovar ou modernizar processos ou tarefas conduzidas pela corporação;

- Estruturas da Indústria e do Mercado: mudanças de grande impacto em setores tradicionalmente estáveis e consolidados que demandam respostas inovadoras por parte da empresa;

- Mudanças Demográficas: alterações na estrutura do público consumidor população, renda, perfil de emprego e renda, etc;

- Mudanças em Percepção: transformações no consciente coletivo que levam a movimentos específicos de consumo diferente do tradicional;

- Conhecimento Novo: em linhas gerais, se confunde com o próprio conceito de inovação, por gerar oportunidades baseadas na descoberta de novos conhecimentos sobre determinados temas, produtos ou serviços.

A realidade da indústria farmacêutica, em particular as que atualmente já investem no desenvolvimento de novos medicamentos, indica que o distanciamento entre o modelo de inovação adotado em suas áreas de Pesquisa e Desenvolvimento e a realidade operacional nas áreas administrativas abre oportunidades para programas que desenvolvam novos modelos internos de atuação junto ao mercado. Assim, para a perspectiva da pesquisa que se pretende 
conduzir a partir deste projeto, considera-se que os fatores mais significativos são "necessidade de processo" e "estruturas da indústria e mercado", conforme descritos por Drucker (1987).

Parte da perspectiva que se pretende analisar nesse contexto é a maneira como os integrantes do setor entendem as oportunidades de inovação e os movimentos internos que se estruturam a partir de uma análise consistente dos movimentos dos diferentes stakeholders no gerenciamento da saúde. Isso porque, em um mercado tão conservador e tradicionalista, mesmo as oportunidades de inovação são vistas como ameaças, criando uma resistência interna e não um movimento natural para torná-las novas iniciativas de geração de valor.

A mudança na estrutura da indústria oferece oportunidades bem visíveis e bem previsíveis para os que estão fora dela, mas os que são do setor vêem essas mesmas mudanças principalmente como ameaças. Os de fora que inovam podem, então, constituir um fator relevante numa indústria ou área importantes em pouco tempo, e a um risco relativamente baixo. (DRUCKER, 1987, p. 110)

\subsubsection{Transformação digital na saúde}

Notoriamente, esse é o caso do que tem havido com o que se convencionou chamar de Digital Healthcare (ou Digital Health) no mercado de saúde atualmente. O crescimento das iniciativas de produtos e serviços digitais para o cuidado de pacientes é resultado do impacto da tardia chegada da transformação digital ao mercado farmacêutico.

Define-se Transformação Digital como a reorientação de um setor, inclusive dos modelos de negócio, a partir da adoção de tecnologias digitais, seja com a criação de novos produtos, serviços ou mesmo a adoção de novos processos (HERMANN et al., 2018; KANE et al., 2015). Reorientação do setor, nesse sentido, não se restringe ao uso de tecnologias, ou à simples adoção de ferramentas digitais, mas especificamente pelo impacto gerado nos resultados de negócio.

Em se tratando de dispositivos de saúde, o papel de mediação da tecnologia é dado pela adoção de dispositivos digitais em diferentes estágios da jornada do paciente, com as principais iniciativas crescendo nos estágios de prevenção, diagnóstico, adesão ao tratamento, engajamento dos pacientes, tratamento, qualidade de vida (HERMANN et al., 2018). Adicionalmente, também podem representar mudanças objetivas nos serviços de saúde, como 
prontuários eletrônicos integrados, registro de impacto nos pacientes e coleta de dados de pesquisas clínicas.

O que se apresenta, nesta medida, é, portanto, uma demanda estratégica para que as empresas compreendam seus negócios para além dos modelos tradicionais, introduzindo progressos culturais e estruturais mediados por ferramentas digitais. No contexto do que se denomina transformação digital, as empresas deveriam, portanto, preparar suas culturas internas para acelerar modelos inovadores baseados na utilização de novas tecnologias, ampliando sua abertura aos riscos e investimento em inovação corporativa.

O que separa os líderes digitais do resto é uma estratégia digital clara combinada com uma cultura e liderança preparada para impulsionar a transformação. A história do avanço tecnológico nos negócios está repleta de exemplos de empresas que focam em tecnologias sem investir em capacidades organizacionais que garantam seu impacto. Em muitas empresas, a implementação fracassada de planejamento de recursos empresariais e gerações anteriores de sistemas de gestão do conhecimento são exemplos clássicos de expectativas frustradas porque as organizações não mudaram mentalidades e processos ou criaram culturas que promovessem mudanças (KANE et al., 2015, p. 05)

Esta realidade, no contexto da saúde, ganha, naturalmente, contornos mais complexos. A área de atuação, por si só, é considerada sensível, por tratar de impactos diretos no bem-estar dos clientes. Neste caso, portanto, as mudanças culturais precisam acelerar o desenvolvimento de soluções, produtos e processos, mas também preservar a segurança regulatória (HERMANN et al., 2018). Essa combinação entre o novo e o tradicional, dada a especificidade do mercado, se torna especialmente complexa para empresas farmacêuticas, que estão desenhando um processo de "migração" para uma atuação digital (KANE et al., 2015). Muitas iniciativas destas empresas neste contexto são superficiais e não prosperam (VAN VELTHOVEN; CORDON; CHALLAGALLA, 2019).

Ainda assim, baseado nas demandas dos consumidores (médicos, pacientes, pagadores), o setor de saúde viu os impactos da mudança serem continuamente ampliados. $\mathrm{O}$ volume de soluções de Digital Health, resultado da transformação digital do segmento, cresceu substancialmente, alavancadas por outros entrantes, não originários do segmento (HERMANN et al., 2018). Grandes players do segmento tecnológico, como IBM, Amazon e Google começaram a desenvolver soluções para pacientes e competir com empresas originárias do setor de saúde pela oferta de produtos e serviços de saúde e bem-estar, como demonstra a imagem a seguir. 
Imagem 08 - Necessidades de saúde e bem-estar atendidas por soluções digitais e distribuição entre players em Digital Health

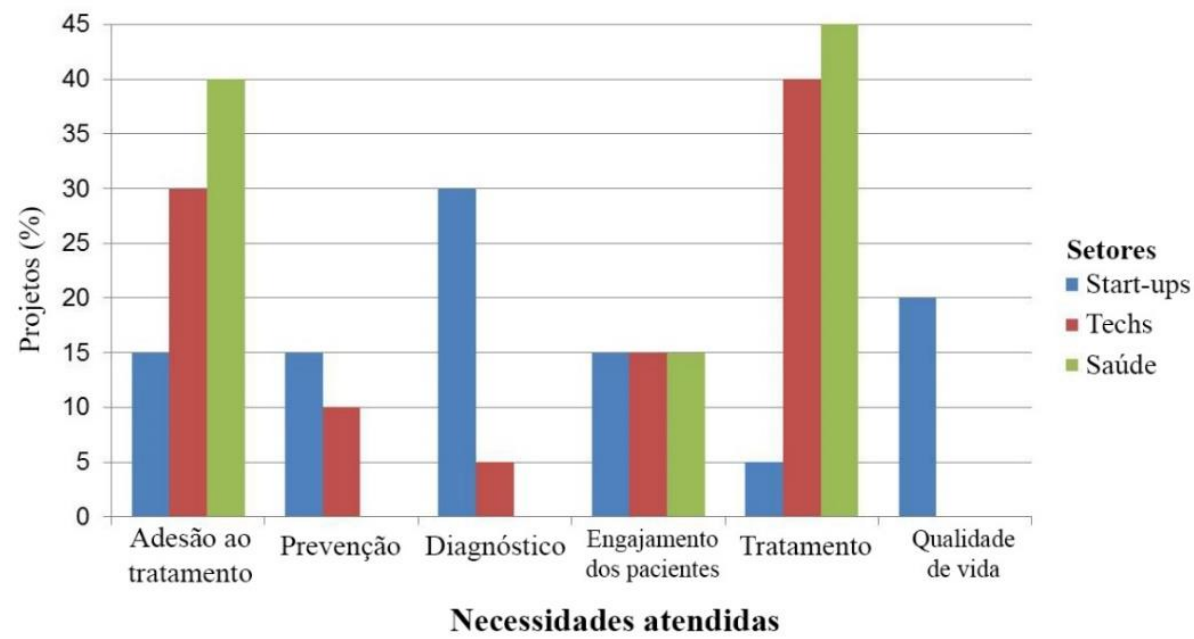

Fonte: HERMANN et al., 2018

Volta a se destacar, nesta perspectiva, a ausência dos players tradicionais da saúde, incluindo as indústrias farmacêuticas, nas etapas da jornada do paciente não envolvidas diretamente com o tratamento.

\subsubsection{Barreiras em Digital Health para as indústrias farmacêuticas}

Sem um líder claro na entrega de soluções digitais para toda a jornada, empresas de outros setores começaram a dividir o espaço com as indústrias farmacêuticas - especialmente startups, mais abertas aos riscos e que buscam por oportunidades em todos as etapas da jornada do paciente. Mais que isso, as empresas que já estão no setor direcionam seus investimentos em soluções incrementais ou que apenas complementam sua atuação, "em torno" da molécula, e não "além da molécula". Os novos competidores, no entanto, atuam buscando construir um amplo espectro de alternativas para todo o ciclo de demandas dos pacientes.

...empresas estabelecidas no setor de ciências biológicas (por exemplo, empresas farmacêuticas) tendem a trabalhar com medicamentos mais eficazes, mas não têm a capacidade de interagir diretamente com o paciente e, portanto, transformar sua posição competitiva por meio de ofertas adicionais (recentemente denominadas "além da molécula"). Alinhados a essa expectativa, identificamos que seus projetos apresentam uma tendência clara de oferecer outputs digitalmente aprimorados, mas tais esforços tendem a ser inovações incrementais que se prendem às estratégias tradicionais de mercado. Curiosamente, fornecedores de produtos de cuidado ao consumidor como Fitbit e Jawbone estão penetrando ainda mais no setor de saúde, indo além de produtos de estilo de vida para clientes interessados em 
automonitoramento de saúde e em direção a ofertas que competem diretamente com corporações de saúde mais estabelecidas, como a Medtronic (HERRMANN et al., 2018).

Volta a revelar-se, portanto, nesse momento, o choque entre a cultura de inovação centrada em P\&D e os modelos tradicionais e conservadores da indústria farmacêutica em geral, em particular daquelas que atualmente já investem no desenvolvimento de novos medicamentos. Como já descrito anteriormente, decisões sobre desenvolvimento de produtos e serviços além da molécula ficam subordinadas à cultura tradicionalista, conservadora e restritiva das áreas operacionais, não seguindo o direcionamento dado ao investimento na criação de novas moléculas (HERRMANN et al., 2018; VAN VELTHOVEN; CORDON; CHALLAGALLA, 2019).

Ainda que se configure, portanto, como uma oportunidade de inovação para o mercado, seja renovando procedimentos internos pela mediação da tecnologia (necessidade de processo, como apontado por Drucker (1987)) ou para o desenvolvimento de novos produtos e serviços (estruturas da indústria e do mercado, ainda Drucker), a estrutura corporativa das indústrias farmacêuticas se mostra como empecilho. As poucas iniciativas conhecidas nessa direção também sofrem na competição direta com empresas mais dinâmicas, como startups, e não progridem de maneira bem-sucedida.

Um problema para todas as organizações é o desafio de inovar com sucesso
na área da saúde. A digitalização revolucionou a sociedade de uma forma que
não poderíamos ter imaginado no século 20 e tem o potencial de interromper
a saúde e lidar com questões de qualidade de longa data, custos crescentes e
recompensa de valor. No entanto, existem muitas inovações de saúde digital
promissoras sem adoção generalizada e muitas intervençóes de saúde digital
são abandonadas quando as pessoas não conseguem escalá-las ou sustentar o
uso ao longo do tempo em uma organização ou em nível de sistema (VAN
VELTHOVEN; CORDON; CHALLAGALLA, 2019, p. 50).

\subsubsection{A armadilha do sucesso para a liderança}

Há que se considerar, também, a perspectiva organizacional no aproveitamento de oportunidades para o desenvolvimento da inovação em grandes corporações. Mais que o chamamento natural à criação de novos produtos, serviços ou negócios, há a necessidade de estruturação de uma cultura corporativa que estabeleça processos fomentadores da inovação, bem como de sua gestão. 
A dificuldade com a qual grandes corporações lidam para fomentar a inovação resulta, em parte, do seu próprio processo de crescimento. Tendo nascido sob um perfil empreendedor, crescem de maneira acelerada até chegarem a um platô de crescimento, quando se estabelecem como empresas de grande porte e permitem desacelerar o ritmo de crescimento, facilitando o processo de gerenciamento da corporação (HISRICH; PETERS; SHEPHERD, 2014). Paralelamente, ampliam mais e mais os processos e ferramentas de planejamento e controle, padronizando as atividades ao máximo limite para reduzir eventuais variações operacionais que impactem o histórico de resultados. Assim, o próprio sucesso repetido atua como elemento de padronização dos objetivos de crescimento e inovação: a meta é "não errar" e, assim, aprender "evitando" o erro; ao invés de crescer assumindo riscos e "aprendendo" com os erros (SITKIN, 1992).

Sitkin (1992) aponta quatro fatores potencialmente limitadores dentro das organizações que resultam da interpretação do sucesso passado como referência para o desenvolvimento futuro. O primeiro é a complacência, que dificulta a experimentação por novas abordagens quando as existentes funcionam (o popular "em time que está ganhando não se mexe"). O segundo fator é o baixo nível de atenção e de busca por informações. Pequenos sucessos do passado se tornam padrão de processos internos independentemente da complexidade do problema atual. Prioriza-se a informação que confirma os procedimentos estabelecidos a menos que algo realmente alarmante aponte para uma ruptura imediata, quando o campo de reação já é limitado. Terceiro, a aversão ao risco, posto que a divergência ao sucesso do passado se determina como uma escolha do líder responsável - a ação é mais expressiva que a falta dela e, portanto, mais fácil de responsabilização. Por fim, o sucesso pode alavancar um processo de homogeneização de processos, equipes, cultura, ações e tomadas de decisão. Nesse sentido, culturas monolíticas tendem a criar ambientes em que as sugestões de mudança sejam emudecidas antes mesmo de serem levantadas em processo de tomadas de decisão.

Adicionalmente, ainda sob a perspectiva dos líderes, Espedal (2002) ressalta a importância do contexto político das organizações como parte da indução da armadilha do sucesso no contexto corporativo. Profissionais em posição de liderança têm interesses próprios - de carreira, de reconhecimento, de remuneração - que podem conflitar com a necessidade de ruptura com o modelo anterior. Nesse contexto, contradizer o caminho bem-sucedido traçado até então, ainda que para adaptação e sobrevivência em um mercado em transformação pode significar choque com a cultura corporativa dominante, o que colocaria em risco os interesses pessoais dos líderes em questão. 
A perspectiva política pode aumentar nossa compreensão do limitado processo de aprendizagem organizacional que é chamado de armadilha do sucesso. Um paradigma estratégico baseado no sucesso torna-se rígido e difícil de mudar, não apenas por razões cognitivas, mas também por causa das implicações políticas que tem. Os atores organizacionais se apegam a um paradigma estratégico e se identificam com ele, não apenas porque o consideram verdadeiro, mas também porque atende aos seus interesses. (ESPEDAL, 2002)

Outra abordagem interessante dessa perspectiva é a narrada por Zibarras, Port e Woods, (2008) que destacam que indivíduos identificados com potencial empreendedor muitas vezes possuem tratos considerados disfuncionais, como arrogância e excentricidade. Embora o estudo tivesse como objetivo estabelecer a relação entre propensão empreendedora e personalidade, os autores ressaltam a dificuldade dos líderes em gerenciar estas características em um ambiente corporativo tradicional. Da mesma forma com que tratam do próprio conflito de interesses, ficam divididos entre controlar estes impulsos de personalidade ao mesmo tempo em que sentem que deveriam facilitar iniciativas inovadoras.

\subsection{SÍNTESE}

A partir da realidade do mercado colocada, os estudos apresentados nesse capítulo apresentam grande valor para o projeto de pesquisa que se pretende realizar. O estudo da inovação em grandes corporações reforça a dualidade do ambiente corporativo das indústrias farmacêuticas em geral e em particular das que investem em criação de produtos e proteção da propriedade intelectual. Enquanto o investimento em inovação é direcionado largamente no desenvolvimento de novos produtos, sem reestruturar a abordagem ao mercado e sua organização interna, estas indústrias repetem exaustivamente modelos bem-sucedidos no passado sem compreender por que seus clientes começam a considerar novas possibilidades.

A visão sobre a gestão estratégica dos stakeholders mostra que as mudanças provocadas pela nova relação de forças do mercado poderiam ter sido previstas e amenizadas a partir de uma estratégia coordenada de geração de valor compartilhado. A excessiva preocupação com a proteção da propriedade intelectual limitou o segmento a seus próprios interesses, colocando em situações de conflito com os organismos responsáveis pela gestão e sustentabilidade do sistema de saúde. 
Considerando a estrutura de identificação de novas oportunidades de inovação proposta por Drucker (1987), é possível ainda mapear movimentos atuais no segmento que servirão como base para direcionamento dos procedimentos metodológicos. Entre as tendências que se apresentam, especialmente Digital Healthcare, o resultado da transformação digital no setor da saúde.

Embora poucos autores tenham abordado o tema em profundidade, é notório que este tem se tornado progressivamente mais relevante no contexto da saúde. Paralelamente, no entanto, análise dos artigos de destaque em publicações científicas especializadas aponta para o fato de que - ao menos no contexto acadêmico - as indústrias farmacêuticas ainda não são um fator de grande relevância.

Por fim, a combinação entre um mercado em transformação, o foco quase exclusivo no desenvolvimento de novos produtos, a falta de estratégias de geração de valor compartilhado com os stakeholders e a ameaça das novas tecnologias ressalta o risco representado pela armadilha do sucesso. A crença inabalável no fato de que os procedimentos anteriores garantirão o sucesso futuro impede o aprendizado, limita a capacidade de inovação e frustra a expectativa de empresas e stakeholders.

\section{PROCEDIMENTOS METODOLÓGICOS}

De acordo com o modelo proposto no Mestrado Profissional, este estudo tem por princípio estruturar uma reflexão que permita conciliar uma visão prática aos constructos teóricos. Assim, considerando o contexto de mercado apresentado, bem como os objetivos que este projeto se propõe a alcançar, o método de pesquisa utilizado foi um estudo multicaso, de perfil exploratório, para compreender, em profundidade, as barreiras nos processos de inovação além da molécula em indústrias farmacêuticas que atualmente já investem no desenvolvimento de novos medicamentos, independente da área terapêutica

Yin (2001) define estudo de caso como "uma investigação empírica que investiga um fenômeno contemporâneo dentro de seu contexto da vida real, especialmente quando os limites entre o fenômeno e o contexto não estão claramente definidos". A escolha deste procedimento metodológico se dá pela necessidade de compreensão dos motivos que impulsionam o desejo pela inovação além da molécula, mas não a efetiva implementação de uma cultura corporativa sustentada por processos de empreendedorismo corporativo. Desta forma, foi utilizado o 
método qualitativo, com apoio de técnica de entrevistas semiestruturadas, gravadas, transcritas e avaliadas por meio da técnica "entrevistar a entrevista", conforme descrita por Sabbag (2002). Considerando, então, a perspectiva de mercado posta anteriormente e a dicotomia da cultura de inovação entre as áreas administrativas e de pesquisa nas indústrias farmacêuticas de oncologia, foram realizados procedimento terão um caráter essencialmente exploratório, que permitam mapear as restrições de investimento em um processo de inovação que não o de desenvolvimento de novos produtos por essa indústria.

Pesquisas exploratórias são desenvolvidas com o objetivo de proporcionar visão geral, de tipo aproximativo, acerca de determinado fato. Este tipo de pesquisa é realizado especialmente quando o tema escolhido é pouco explorado e torna-se difícil sobre ele formular hipóteses precisas e operacionalizáveis. (GIL, 2010, p. 27)

\subsection{ESTRUTURAÇÃO DA PESQUISA}

A imagem 09, abaixo, representa, em linhas gerais, o procedimento metodológico utilizado. A partir da experiência do autor no segmento estudado, foi possível observar os conflitos inerentes às necessidades emergentes das mudanças nas forças relativas do mercado de saúde no Brasil e a abordagem tradicional no desenvolvimento de novos produtos adotada pelas indústrias de saúde que investem em P\&D. Esta observação colaborou para a formatação do problema de pesquisa e a consequente estruturação deste projeto.

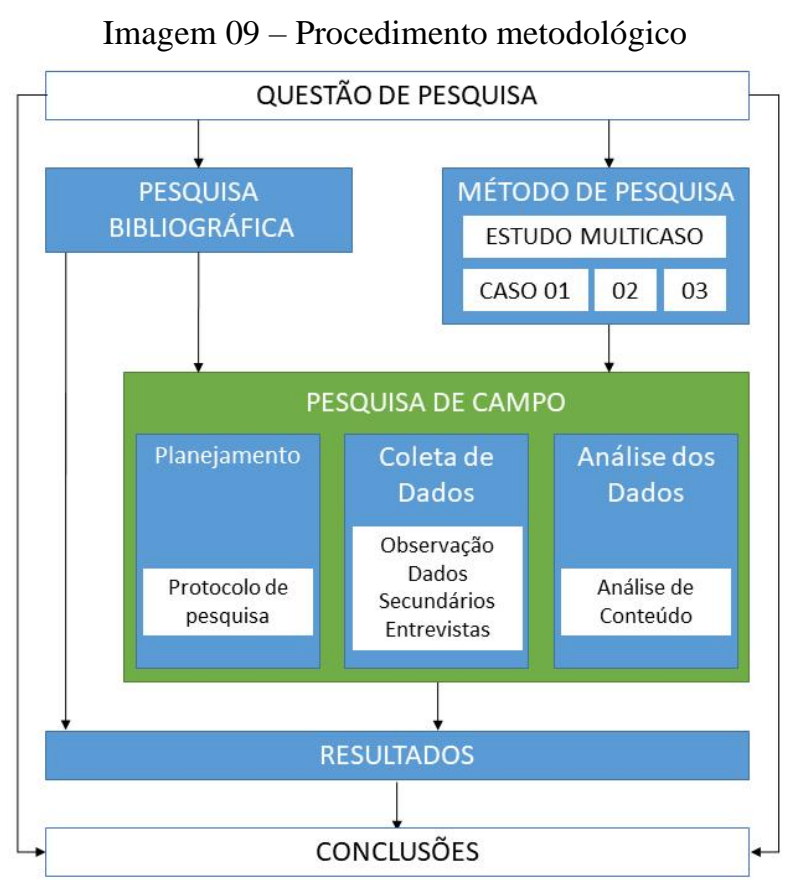

Fonte: Elaborado pelo autor 
Para a pesquisa bibliográfica, foram utilizados livros, artigos científicos e publicações acadêmicas para estruturar uma revisão teórica que permitisse ampla compreensão dos assuntos abordados. Para esta pesquisa, os principais temas utilizados foram: gestão de stakeholders, teoria dos stakeholders, inovação na indústria farmacêutica, inovação além da molécula, digital health, transformação digital na indústria farmacêutica, jornada do paciente e empreendedorismo corporativo, com busca prioritariamente na base de dados Web of Science e, em alguns casos, no Google Acadêmico.

Uma vez desenvolvida a pesquisa para revisão da literatura dos tópicos acima referidos, foi elaborado o protocolo para a pesquisa de campo. Esta se focou no entendimento em profundidade do contexto de inovação de diferentes competidores no desenvolvimento de soluções no sistema de saúde brasileiro.

A coleta de campo foi realizada por meio de entrevistas semiestruturadas e pesquisa documental. Em dois dos casos, também se considera observação participante do autor. Dado o contexto de afastamento social provocado pela pandemia de COVID-19, parte das entrevistas foi realizada a distância, por meio eletrônico, não sendo possível a realização de visitas às sedes das empresas envolvidas nos casos analisados. Após a etapa de coleta de dados e transcrição das entrevistas realizadas, foi conduzida análise de conteúdo, combinando os resultados consolidados com a revisão bibliográfica.

Os sites das empresas, bem como demais canais digitais, como redes sociais, também foram consultados durante a pesquisa documental para delimitação do campo de atuação das mesmas. Veículos de comunicação focados em negócios, pesquisas de mercados e outros canais de veiculação de notícias foram utilizados para consolidar as tendências de mercado observadas diretamente pelo autor, como profissional do segmento. Também foram analisadas separadamente as unidades de análise de cada caso para descrição dos resultados e conclusões com foco na questão de pesquisa estabelecida anteriormente, bem como nos objetivos secundários. Por fim, foram consideradas possíveis contribuições futuras deste estudo.

Para consolidação da relação entre a revisão teórica e a pesquisa de campo, possibilitando a revisão, foi estruturada uma versão modificada da matriz de amarração proposta por Telles (2001) a partir do modelo de Mazzon. Esta demonstra consistência interna no procedimento metodológico, reforçando a visão sistêmica na construção do projeto de pesquisa. 
Tabela 02 - Matriz de amarração

\begin{tabular}{|c|c|c|c|}
\hline \multicolumn{2}{|c|}{ Questão de pesquisa } & \multicolumn{2}{|c|}{ Método de pesquisa } \\
\hline Objetivo Principal & Objetivos Específicos & Pesquisa de campo & Revisão bibliográfica \\
\hline $\begin{array}{l}\text { Identificar caminhos } \\
\text { para inovação além da } \\
\text { molécula no setor da } \\
\text { saúde e observar de que } \\
\text { maneira estes se } \\
\text { contrapõem à tradicional } \\
\text { gestão da inovação da } \\
\text { indústria farmacêutica, } \\
\text { focada no } \\
\text { desenvolvimento e } \\
\text { proteção de } \\
\text { propriedades } \\
\text { intelectuais }\end{array}$ & $\begin{array}{l}\text { Identificação e análise } \\
\text { de barreiras internas da } \\
\text { indústria farmacêutica } \\
\text { que afetam a tomada de } \\
\text { decisão pelo } \\
\text { investimento em } \\
\text { inovação além da } \\
\text { molécula }\end{array}$ & $\begin{array}{ll}\text { - } & \text { Modelo de } \\
\text { monitoramento e } \\
\text { gestão de stakeholders } \\
\text { - } & \text { Movimentações na } \\
\text { força relativa dos } \\
\text { stakeholders } \\
\text { Abertura ao risco na } \\
\text { inovação além da } \\
\text { molécula } \\
\text { Armadilha do sucesso } \\
\text { e gestão de mudança } \\
\text { Limitações de } \\
\text { investimento local } \\
\text { (empenhado em } \\
\text { marketing e vendas) }\end{array}$ & $\begin{array}{l}\text { Bastos, 2005 } \\
\text { Chen et al., } 2018 \\
\text { Civaner, } 2012 \\
\text { Dimasi, Hansen, } \\
\text { Grabowski, } 2003 \\
\text { Dos Santos; Ferreira, } \\
2012 \\
\text { Espedal, 2002 } \\
\text { Grabowski, } 2002 \\
\text { Jannuzzi; Vasconcellos; } \\
\text { de Souza, 2008 } \\
\text { Kaufmann, } 2004 \\
\text { Kline; Rosenberg, } 1986 \\
\text { Saleh; Wang, } 1993 \\
\text { Sitkin, 1992 } \\
\text { Zibarras; Port; Woods, } \\
\text { 2008 }\end{array}$ \\
\hline & $\begin{array}{l}\text { Identificar processos de } \\
\text { busca por novas } \\
\text { oportunidades de } \\
\text { inovação além da } \\
\text { molécula oriundas da } \\
\text { gestão estratégica dos } \\
\text { stakeholders }\end{array}$ & $\begin{array}{ll}\text { - } & \text { Impactos na jornada do } \\
\text { paciente } \\
\text { - } & \text { Demandas específicas } \\
\text { de clientes e pacientes } \\
\text { - } \\
\text { Monitoramento e } \\
\text { melhoria na adesão ao } \\
\text { tratamento } \\
\text { Suporte de dados para } \\
\text { incorporação a rol de } \\
\text { medicamentos } \\
\text { (sistemas público e } \\
\text { privado de saúde) }\end{array}$ & $\begin{array}{l}\text { Anwar; Chowdhry; } \\
\text { Prasad, } 2018 \\
\text { Drucker, } 1987 \\
\text { Freeman et al., } 2018 \\
\text { Freeman, } 2004 \\
\text { Freeman, } 2010 \\
\text { Krishna, } 2018 \\
\text { Sestelo; de Souza; } \\
\text { Bahia, 2013 } \\
\text { Trapp; Voigt; Brem, } \\
2018\end{array}$ \\
\hline & $\begin{array}{l}\text { Observar boas práticas } \\
\text { em inovação além da } \\
\text { molécula a partir de } \\
\text { modelos de interação de } \\
\text { novos atores no setor } \\
\text { brasileiro de saúde } \\
\text { (healthtechs e biotechs) }\end{array}$ & $\begin{array}{ll}\text { - } & \text { Desenvolvimento de } \\
\text { produtos e serviços de } \\
\text { base tecnológica } \\
\text { - } & \text { Parcerias com } \\
\text { ecossistema de } \\
\text { inovação } \\
\text { Programas de incentivo } \\
\text { ao } \\
\text { intraempreendedorismo }\end{array}$ & $\begin{array}{l}\text { Freeman et al., } 2010 \\
\text { Hisrich; Peters; } \\
\text { Shepherd, } 2014 \\
\text { Kane et al., } 2015 \\
\text { Schuhmacher et al., } \\
2020 \\
\text { Van Velthoven; Cordon; } \\
\text { Challagalla, } 2019\end{array}$ \\
\hline
\end{tabular}




\subsection{PLANEJAMENTO DA PESQUISA}

O planejamento da pesquisa considerou as seguintes etapas: escolha das empresas que teriam seus casos estudados; definição dos entrevistados, entre líderes e colaboradores das empresas selecionadas; estruturação do protocolo de pesquisa.

\subsubsection{Escolha das empresas}

Uma vez que este estudo pretende identificar barreiras à inovação dentro do atual modelo de gestão das indústrias farmacêuticas e, paralelamente, observar boas práticas em novos entrantes do setor de saúde, os casos a serem estudados se dividirão em dois perfis diferentes de empresas, descritos a seguir:

\section{Perfil 1}

a. Indústria farmacêutica, privada, com fins lucrativos;

b. Empresa multinacional (de origem não-brasileira), de grande porte (número de colaboradores e faturamento) ${ }^{10}$;

c. Listada entre as 50 empresas que mais investem em P\&D no mundo, cujo foco de mercado seja criação de novas patentes de medicamentos, independente da área terapêutica;

d. Que tenha submetido pedido de avaliação de incorporação de medicamento no rol do SUS entre 2019 e 2020, independente do resultado do processo.

Considerando os critérios acima, observa-se que o primeiro caso (doravante nomeado Caso 01) trata de uma das maiores indústrias farmacêuticas do mundo, com vasta representatividade no desenvolvimento de novas moléculas. Também ocupa posição relevante na lista de maiores empresas do país, onde conta com cerca de 1.500 funcionários.

Para o segundo perfil, que enfoca no comportamento de startups que investem ativamente em inovação além da molécula, será subdividido em dois casos, a partir da natureza das empresas. A única diferença para seleção entre eles será a área de atuação, como detalhado a seguir:

\footnotetext{
${ }^{10}$ Considerando critérios definidos pela lei $\mathrm{n}^{\mathrm{0}} 11.638$, de 28 de dezembro de 2007.
} 


\section{Perfil 2}

a. Startup, menos de sete anos de fundação;

b. Empresa que já tenha linhas de faturamento próprias (não dependa exclusivamente de aporte dos sócios); ou que já tenha recebido aporte em rodadas de investimento; ou que já tenha sido incubada;

c. Listada no mapeamento Liga Insights 2018 entre as pioneiras do segmento HealthTech no Brasil;

d. Ao menos uma startup focada em desenvolvimento de soluções de tecnologia para saúde sem conexão com desenvolvimento de medicamentos; ao menos uma startup do segmento hard science, com soluções de inovação além da molécula no processo de pesquisa;

e. Relacionamento com stakeholders do segmento de saúde que também mantenham relacionamento com indústrias farmacêuticas (agências reguladoras, prestadores de serviço, pagadores, pacientes).

Definidos os critérios acima, duas empresas corresponderão aos casos 02 e 03, da seguinte maneira:

Tabela 03 - Casos escolhidos, perfil 2

\begin{tabular}{|c|c|c|}
\hline Critérios & Caso 02 & Caso 03 \\
\hline $\begin{array}{l}\text { a. Startup, menos de sete anos de } \\
\text { fundação; }\end{array}$ & Fundada em 2017 & Fundada em 2015 \\
\hline $\begin{array}{l}\text { b. Empresa que já tenha linhas de } \\
\text { faturamento próprias (não } \\
\text { dependa exclusivamente de } \\
\text { aporte dos sócios); ou que já } \\
\text { tenha recebido aporte em } \\
\text { rodadas de investimento; ou } \\
\text { que já tenha sido incubada; }\end{array}$ & $\begin{array}{l}\text { Duas rodadas de aporte realizadas } \\
\text { além do investimento dos sócios. } \\
\text { Empresa incubada. Produtos } \\
\text { lançados comercialmente. }\end{array}$ & $\begin{array}{l}\text { Três rodadas de captação de } \\
\text { recursos Fapesp. Empresa } \\
\text { incubada. Serviços oferecidos } \\
\text { comercialmente. }\end{array}$ \\
\hline $\begin{array}{l}\text { c. Listada no mapeamento Liga } \\
\text { Insights } 2018 \text { entre as } \\
\text { pioneiras do segmento } \\
\text { HealthTech no Brasil; }\end{array}$ & Sim & Sim \\
\hline d. Área de concentração; & Tecnologia em saúde & Hard Science \\
\hline $\begin{array}{l}\text { e. } \\
\text { stakeholacionamento com } \\
\text { saúde que também }\end{array}$ & Sim & Sim \\
\hline
\end{tabular}


mantenham relacionamento

Fonte: Elaborado pelo autor

\subsubsection{Definição dos entrevistados}

Dados os objetivos estabelecidos para o trabalho, os perfis prioritários dos entrevistados foram definidos como colaboradores (preferencialmente em posição de liderança) que participam do processo de tomada de decisão pelo investimento em inovação além da molécula - seja como propositor de soluções ou como tomador de decisão acerca do investimento. Uma vez definidas as empresas e os projetos que seriam estudados, foram enviados convites eletrônicos, por e-mail, junto à carta de apresentação do projeto de pesquisa.

Para o caso 01, a carta foi enviada à diretoria de Comunicação, que fez as indicações dos participantes do projeto a ser estudado. Para os casos 02 e 03, a carta foi enviada aos sóciosfundadores, que se disponibilizaram a participar das entrevistas para descrever os projetos a serem estudados. Cumprido o critério de participação no processo de decisão no investimento de inovação além da molécula, a empresa relatada no caso 01 têm um número maior de entrevistados, dada sua natureza e porte.

Duas das três empresas convidadas solicitaram sigilo de suas marcas e informações estratégicas para integrar o projeto de pesquisa. Posto que este procedimento já havia ocorrido com convites anteriores a outras empresas, e dada a relevância dos projetos estudados, a opção foi de assegurar o anonimato e o sigilo a todas as empresas envolvidas.

Uma vez formalizada a participação dos entrevistados, foram agendadas as entrevistas. No agendamento, foram passadas as seguintes informações:

a. Sobre a coleta dos dados: cada entrevista teria duração prevista de 45 a 60 minutos, sendo do tipo semiestruturada, com base em um roteiro de temas com perguntas abertas (respostas livres);

b. Sobre o registro das entrevistas: todas as entrevistas seriam gravadas para fim de documentação. Havendo alguma restrição quanto ao registro, os convidados deveriam informar antecipadamente para indicação de substituto pela empresa. Durante as gravações, caso algum trecho não pudesse ser gravado, o convidado 
deveria informar para interrupção da gravação no momento especificado ou recusarse a responder à pergunta. Os entrevistados também foram informados de que poderiam solicitar posteriormente as gravações;

c. Análise das respostas: todas as respostas seriam avaliadas conjuntamente às demais entrevistas, não permitindo identificação e garantindo a confidencialidade.

As entrevistas foram realizadas entre janeiro e novembro de 2020, todas por meio digital (Google Meet) - a maior parte da agenda fortemente impactada pela pandemia de Covid-19. Todos os entrevistados permitiram que as entrevistas fossem gravadas, uma vez resguardada a opção das empresas de que os nomes não fossem mencionados.

Tabela 04 - Lista de entrevistados

\begin{tabular}{|c|c|l|}
\hline Caso de estudo & Entrevistado & Cargo \\
\hline 01 & $01 \mathrm{~A}$ & Head global e-Heath - Área terapêutica \\
\hline 01 & $01 \mathrm{~B}$ & Gerente de produto A - Início do projeto \\
\hline 01 & $01 \mathrm{C}$ & Gerente de produto B - Final do projeto \\
\hline 01 & $01 \mathrm{D}$ & Gerente médico \\
\hline 01 & $01 \mathrm{E}$ & Coordenador Digital \\
\hline 01 & $01 \mathrm{~F}$ & Gerente Digital \\
\hline 02 & $02 \mathrm{~A}$ & Sócio-Fundador \\
\hline 02 & $02 \mathrm{~B}$ & Sócio-Fundador - CIO \\
\hline 03 & 03A & Sócio-Fundador \\
\hline 03 & $03 \mathrm{~B}$ & Sócio-Fundador \\
\hline
\end{tabular}

Fonte: Elaborado pelo autor

\subsubsection{Protocolo de entrevista}

Primeiro, as questões são feitas a você, o pesquisador, não ao respondente. São, em essência, os lembretes que você deverá utilizar para lembrar das informações que precisam ser coletadas e o motivo para coletá-las. (YIN, 2001, p. 95)

Como descrito por Yin (2001), o protocolo de entrevista foi utilizado para guiar as entrevistas semiestruturadas, realizadas por meio de perguntas abertas. A partir dos temas mapeados na contextualização do mercado e na revisão teórica, o roteiro foi construído para responder aos objetivos colocados como definidores da pesquisa, sem, no entanto, limitar a coleta dos dados às perguntas estipuladas no referido protocolo. Deu-se preferência ao uso de perguntas abertas na construção do protocolo de entrevista pelo caráter exploratório do estudo dos casos selecionados (GIL, 2002), focando na compreensão do fenômeno de inovação além da molécula em virtude das mudanças vividas no segmento de saúde. 


\section{RESULTADOS E DISCUSSÃO}

A partir das entrevistas realizadas, serão estruturadas, a seguir, as análises dos três casos de estudo. Em busca de cumprir os objetivos propostos para a pesquisa, os três casos serão analisados de acordo com a seguinte estrutura:

I. Descrição do caso

II. Gestão da inovação

III. Gestão estratégica dos stakeholders

IV. Transformação digital e armadilha do sucesso

\subsection{ANÁLISE DO CASO 01}

Conforme descrito anteriormente, o Caso 01 trata de uma indústria farmacêutica multinacional com operação comercial e logística no Brasil. A empresa não conta, atualmente, com laboratórios de P\&D no país e, da mesma forma, não fabrica localmente os produtos distribuídos no mercado brasileiro. Assim, a opção é pelo registro e proteção intelectual internacional, por meio do desenvolvimento de novos fármacos ou medicamentos biológicos em laboratórios na matriz. Nesta configuração, à filial brasileira cabem as atividades de mercado - compreensão do mercado local, publicidade, atuação comercial e logística. As diretrizes de atuação, no entanto, são definidas pela hierarquia geográfica entre matriz global, matriz regional e filial.

\subsubsection{Descrição do caso}

Após doze anos de desenvolvimento, a empresa 01 estava preparando o lançamento de um novo medicamento biológico. O novo produto era destinado ao tratamento de uma doença rara $^{11}$, crônica, progressiva e que afeta o sistema nervoso central. Também se tratava, naquele momento, de uma área terapêutica desconhecida para a empresa, que não possuía experiência anterior com medicamentos para esse tratamento. Adicionalmente, a doença tratada pelo

\footnotetext{
${ }^{11}$ Seguindo a classificação da OMS para doenças raras, a referida doença é considerada rara especificamente no Brasil. Em outros países, com maior incidência, não se classifica como doença rara
} 
fármaco tem dados epidemiológicos que variam de acordo com a demografia - em alguns países a incidência de casos é maior que em outros, o que faz com que seja considerada rara no Brasil, mas não em outros mercados de grande porte, como EUA, Canadá, Espanha e Alemanha.

Ainda que seja considerada rara no Brasil, no entanto, a doença tem um mecanismo bastante conhecido, bem como seus efeitos. Diversos medicamentos disponíveis no mercado tratam seus efeitos no paciente e muitos deles, inclusive, já estão incorporados ao rol de medicamentos reembolsados pelo Ministério da Saúde. Apesar disso, o novo medicamento teria um custo superior aos tratamentos existentes por se tratar de uma nova classe de fármacos. Mesmo nessa nova classe, não seria o primeiro, pois já existiam outras opções lançadas no mercado brasileiro.

Dado o investimento realizado no desenvolvimento do medicamento, a empresa estimava que este tinha potencial para ser um dos principais lançamento da empresa na década. Algumas de suas principais patentes estavam chegando, naquele momento, a etapa final do ciclo de vida do produto (os direitos de proteção encerrariam entre três e quatro anos após o período deste relato) e, portanto, a matriz havia optado por acelerar o investimento na criação de novas propriedades intelectuais para renovar o portfólio de licenças.

Neste contexto, o papel das filiais cresceu em importância. Era preciso aprofundar o conhecimento no novo mercado e garantir assertividade nas ações de pré-lançamento e lançamento para que a adoção fosse rápida. Também havia a oportunidade de identificar outros caminhos e iniciativas novas, além do padrão de abordagem de lançamento de novas moléculas no mercado. Como já citado, no Brasil se trata de uma doença rara, o que demanda um investimento maior em encontrar os pacientes corretos para o uso da medicação, além de lidar com a complexidade do sistema de saúde local.

A avaliação da filial brasileira naquele momento foi de que se tratava de um lançamento complexo. O cenário político-econômico brasileiro não era favorável à incorporação de medicamentos de alto custo em substituição aos já disponíveis. O cenário epidemiológico também não era claro, pois, além do número de casos classificarem a doença como rara, havia a suspeita de subnotificação, dada a complexidade do diagnóstico. Por fim, internamente, a pressão por parte da matriz por um lançamento bem-sucedido e com rápida adoção em todas as filiais.

Neste contexto, um grupo de colaboradores da filial brasileira entendeu que havia a oportunidade de desenvolver um aplicativo digital (doravante denominado "aplicativo Brasil"), 
para uso em smartphones, como ferramenta adicional ao tratamento. Este teria o papel de acelerar e otimizar a comunicação entre médicos e pacientes permitindo o mapeamento do estado de saúde entre as consultas e ajudando na melhor avaliação de abordagem clínica. Também seria um repositório das informações do paciente ao longo do acompanhamento clínico - resultados de testes cognitivos e motores, para monitorar a progressão da doença; registro de prescrições; dados sobre consultas e exames; monitoramento emocional.

Adicionalmente, este aplicativo poderia servir como base de captação e estruturação de dados sobre essa área terapêutica, até então não conhecida em profundidade pela empresa. Uma vez disponibilizado e adotado pela comunidade de médicos e pacientes, o aplicativo Brasil poderia se configurar como uma fonte rica de informações sobre os tratamentos, os chamados dados de mundo real, que complementam os dados de testes clínicos. Estes poderiam, futuramente, ser usados para enriquecer as informações sobre o produto e auxiliar em uma eventual submissão de incorporação ao SUS. Para o grupo responsável pelo desenho do projeto, a iniciativa poderia ser a primeira de uma linha de gerenciamento de dados em saúde que, futuramente, poderia se consolidar como uma nova linha de faturamento.

$\mathrm{Na}$ avaliação da liderança de marketing do produto, parecia ser uma oportunidade interessante, mas os líderes responsáveis não tinham clareza da contribuição para a adoção e expansão do novo fármaco. Embora comparado a outras iniciativas de marketing o custo de desenvolvimento da aplicação não fosse alto, a análise foi de que era preciso cumprir ainda algumas etapas de avaliação do investimento sob a ótica de desempenho do novo produto. Da mesma forma, o custo para realizar uma pesquisa qualitativa em detalhe com os públicos de interesse (médicos, pacientes, agentes de saúde e administradores - públicos e privados) era relativamente alto - um estudo epidemiológico, em comparação, custaria o equivalente a $48 \%$ deste novo estudo. Optou-se, então, por um estudo de benchmarking para avaliação de ferramentas semelhantes e seu impacto no tratamento.

Em paralelo, demais iniciativas consideradas padrão do segmento estavam em andamento. A equipe de visitação médica já estava em processo de seleção e o planejamento de autorização regulatória em andamento. Materiais promocionais para abordagens a prescritores estavam prontos, agenda promocional e de eventos também já estruturada e com investimentos garantidos. Os processos de lançamento estavam preparados, à espera da aprovação regulatória por parte da Anvisa para iniciar a divulgação e comercialização. 
O estudo de benchmarking da disponibilidade de aplicativos mostrou que não havia nada tão amplo quanto o proposto para ser o aplicativo Brasil para acompanhamento da doença em questão. Uma startup já possuía, naquele momento, uma versão digital de um dos testes motores usados como padrão de diagnóstico, o que poderia ser incorporado dentro do aplicativo Brasil como uma funcionalidade de monitoramento do estado de saúde dos pacientes. Outra startup oferecia serviço de integração com a base de dados do DataSUS, do Ministério da Saúde. A análise de benchmarking, no entanto, deu início a uma divergência interna - para os times de Inovação e de Tecnologia Digital, significava uma oportunidade a ser explorada; para parte do time de marketing de produto, demostrava ausência de demanda.

Acionada, parte da liderança sênior da empresa entendeu que havia a necessidade de uma abordagem diferente ao mercado, dado o contexto citado anteriormente. Tinham dúvidas, no entanto, se o aplicativo Brasil cumpriria esse papel, pela falta de experiência da empresa com o tema. Também, apontaram incertezas quanto ao valor do investimento. Se deveria ser usado para desenvolvimento da solução digital ou para reforçar as demais ações de marketing planejadas, especialmente na primeira etapa do ciclo de vida do produto. Àquele momento, a estimativa de custo de desenvolvimento do aplicativo era equivalente à realização de um evento presencial de lançamento para cerca de 200 médicos.

Em meio às discussões locais sobre o desenvolvimento ou não da oportunidade identificada, a matriz da empresa anunciou a criação de uma área de serviços digitais, que lançaria um aplicativo de monitoramento de saúde (doravante chamado aplicativo Global) para a área terapêutica do novo produto. Como uma solução centralizada, no entanto, ele seria desenvolvido de acordo com o calendário da matriz e priorizaria países com maior incidência epidemiológica. Também seria registrado em todos os países como um estudo clínico, seguindo, portanto, as mesmas regras regulatórias de estudos para criação de um medicamento.

Para o Brasil, o cronograma previa o lançamento do aplicativo Global logo após a aprovação regulatória do medicamento pela Anvisa. E, por ser um programa centralizado, com financiamento pela estrutura da Matriz, não teria adaptações à realidade do mercado brasileiro. A versão implementada nos demais países seria traduzida e localizada para lançamento no Brasil. Naquele momento, portanto, a filial teria a decisão de optar pelo ingresso no projeto do aplicativo Global ou antecipar as ações e investir no desenvolvimento do aplicativo Brasil para acompanhar a entrada em uma nova área terapêutica. 
A definição pelo aplicativo Global, feita pela liderança, destinou os recursos então previstos para o aplicativo Brasil para reforço do plano de marketing. Para a empresa, no entanto, estava clara a necessidade de direcionamento para alternativas de reembolso no país seja por meio de incorporação ao SUS, seja por inclusão no rol da ANS. A intenção assim, passou a ser de contar com o aplicativo Global para gerar eventuais dados que suportassem esses processos, mesmo que seu objetivo não fosse esse.

Um ano após o processo decisório relatado acima, o medicamento recebeu aprovação de comercialização pela Anvisa. Embora a expectativa pelo aplicativo Global fosse alta, o cronograma havia sido modificado e previsão de lançamento no país estava sendo reajustada pela equipe da Matriz responsável. Neste mesmo ano, cerca de seis meses após a aprovação, ainda no primeiro ano do produto no mercado, a farmacêutica solicitou ao Ministério da Saúde a incorporação do medicamento ao rol de produtos reembolsados pelo SUS, pedido que foi negado pelo alto custo, falta de informações de segurança em longo prazo e eventual impacto nas contas públicas ${ }^{12}$.

Embora eficaz ${ }^{13}$ do ponto de vista clínico, o produto começou a demonstrar dificuldades de penetração no mercado brasileiro. A falta de reembolso do tratamento pelo SUS ou por planos de saúde faziam com que estivesse disponível apenas por pagamento direto pelo paciente (cada dose a um custo aproximado de $\mathrm{R} \$ 40.000$ ) ou por meio de ordem judicial. O apoio de outros agentes do setor também não se mostravam efetivos na busca pelo reembolso. Associações médicas e de pacientes não se comprometiam diretamente com o discurso de incorporação do medicamento.

Internamente, seguia a pressão pelo desempenho do novo produto no mercado local. No segundo ano do produto no mercado, os resultados seguiam abaixo do esperado e o portfólio seguia sob ameaça. Entre o primeiro e o segundo ano do novo produto no mercado, a Anvisa aprovou versões similares, produzidas por concorrentes, de duas das principais propriedades intelectuais da empresa cujas patentes perderam a validade - produtos até então líderes dos seus respectivos mercados. Paralelamente, a entrega do aplicativo Global para o mercado brasileiro foi postergada por duas vezes ao longo do segundo ano do produto no mercado.

No primeiro trimestre do terceiro ano do produto no mercado, o aplicativo Global foi lançado. Como dito anteriormente, sem uma configuração específica para o mercado brasileiro.

\footnotetext{
${ }^{12}$ De acordo com relatório público emitido pela Conitec

${ }^{13}$ De acordo com estudos clínicos publicados
} 
Ao chegar no Brasil, já carregava uma série de resultados abaixo do esperado nos mercados com maior proporção de pacientes na área terapêutica do produto. Assim, mesmo a estratégia de localização da filial brasileira foi sobreposta pelas decisões da Matriz sobre como o aplicativo Global deveria ser conduzido. Sem adaptações às especificidades do mercado brasileiro, o aplicativo teve um baixo índice de adoção inicial, praticamente $80 \%$ abaixo do projetado pela empresa.

Neste mesmo terceiro ano de mercado, a empresa faria ainda duas novas tentativas de incorporação do novo medicamento ao SUS. Primeiro, com dados comparativos buscando demonstrar superioridade ao tratamento já padronizado pelo Ministério da Saúde. Em seguida, direcionando o pedido para uma indicação secundária, por ser uma necessidade médica não atendida. Sem novos dados para agregar à documentação de solicitação, no entanto, viu ambos serem recusados pela Conitec, com justificativa semelhante à dada anteriormente: alto custo, baixa relação de custo-efetividade e falha em demonstrar superioridade ao tratamento já padronizado no sistema público de saúde. Ao final do terceiro ano de mercado do novo produto no Brasil, a Matriz da empresa anunciou o encerramento do aplicativo Global e sua retirada das lojas de aplicativo.

\subsubsection{Gestão da inovação}

A análise do caso reforça a ideia do foco da indústria na criação e renovação do portfólio de propriedades intelectuais. É o caminho "natural" adotado pela empresa, principalmente em um cenário de erosão do portfólio. Assim, mesmo quando há a percepção de uma necessidade de mercado específica para ajuste a um novo contexto, o que Drucker (1987) define como oportunidades oriundas das Estruturas da Indústria e do Mercado, a opção é por reforçar a inovação de produto ou mesmo "em torno" da molécula, e não "além” da molécula.

Entrevistado 01C: “A primeira coisa em que eu penso quando se faz a comparação com o ambiente de $P \& D$, bancada, molécula versus a gestão do negócio, acho que o cientista tem muito mais clara a necessidade da inovação, porque isso já faz parte do dia-a-dia deles, por causa das inspirações de patente ou porque a ciência evolui de uma maneira muito mais tangível, né? Acho que pela questão da publicação dos dados, você tem uma corrida pela próxima fronteira da ciência, digamos assim, e isso faz parte da sobrevivência do negócio" 
Entrevistado 01B: "Naquele momento, era muito difícil pensar na entrada do medicamento no Brasil e a cadeia como um todo. Era preciso desenvolver todo o plano de marca, toda a comunicação em volta da marca que, olhar o cliente não é tão simples como a gente pensa, assim, por todas essas nuances. Na construção do plano, só valeria incluir um aplicativo se a base de dados desse as informações que iriam trazer um determinado benefício para o produto"

Entrevistado 01F: "No marketing que a gente faz hoje na indústria farmacêutica como um todo, não é exatamente o marketing de valor, é marketing de 'o produto tem 10 meses de sobrevida global'. Acho que, hoje, quando falamos além da molécula, ainda pensamos em um além 'partindo' da molécula. Não é um além como 'está aqui o medicamento, agora a gente vai criar uma solução para o sistema,",

O investimento financeiro na criação da molécula sustenta boa parte dos argumentos de manutenção das práticas de mercado. É como se todo o risco disponível para determinada operação já tivesse sido investido na criação de um novo fármaco. A cultura da empresa difunde a imagem do centro de P\&D como a origem de toda a inovação da companhia. Com a maioria das diretrizes emanando da matriz, cria-se um bolsão de inovação, isolado da estrutura corporativa, como afirma Krishna (2018). O processo de reporte se torna um imobilizador de inovações de grande porte que eventualmente possam surgir nas filiais.

Entrevistado 01C: “Os gestores são muito focados na rentabilidade, na entrega imediata e isso, na minha opinião, traz a barreira de você não tomar a decisão que talvez seja a mais disruptiva, mais inovadora, mas é para trazer resultado mais imediato. E aí pode criar um distanciamento do que pode ser o super disruptivo, que vai levar para um lugar melhor no futuro e o que vai trazer talvez uma percepção de resultado, porque talvez nem seja o resultado em si, mas é o que traz uma percepção. Por isso que eu acho que as pessoas ficam rodando nas mesmas soluções, digamos assim"

Esse bolsão de inovação se mostra mesmo em circunstâncias outras que não o investimento da criação de novos fármacos. O caso avaliado trata, especificamente, da criação de uma solução digital para o tratamento - que, potencialmente, ajudaria a penetração do medicamento no mercado. Uma solução que poderia ser desenvolvida em qualquer mercado, o que, inclusive, reforçaria o atendimento a especificidades locais. O modelo de inovação, nesse caso, no entanto, submete-se à centralização dos investimentos e do conhecimento dentro da 
estrutura corporativa, abrindo mão do benefício da diversidade de capacidades de diferentes filiais.

Sob essa perspectiva, o risco transfere-se para a Matriz, que assume a responsabilidade de entregar soluções "prontas" aos mercados. A entrega massificada, por sua vez, coloca a corporação em um paradoxo - a Matriz satisfeita pela centralização dos custos e escalabilidade das soluções; as filiais engessadas na sua função central de reconhecimento e abordagem ao mercado local.

Entrevistado 01D: “Acredito que os países não têm autonomia para isso, eu acho que isso vem... como existe um investimento muito alto na criação da solução, da perspectiva da global, eu acho que eles não veem valor ou eles não acreditam no desenvolvimento local, eu acho que tem isso. Ainda tem a centralização ali nos headquarters, então, é guiado por eles. Eu não estou falando que seja o melhor, mas é a forma que eu vejo que acontece, hoje."

Entrevistado 01F: “As decisões da Matriz são pragmáticas e consideram processos que não necessariamente se estendem aos países. $O$ aplicativo Global sempre foi tratado como um medicamento porque assim eles têm uma visão muito clara de procedimentos regulatórios. Quando dizíamos que a implementação do aplicativo Global que estava sendo conduzida não refletia o mercado brasileiro eles não se moviam, porque, na cabeça deles, os procedimentos regulatórios que precisavam ser implementados foram cumpridos. Porque é assim que eles fazem medicamento”

Entrevistado 01B: "Nós escolhemos seguir com o aplicativo Global, mas não éramos prioridade no processo. E ignoramos todo o resto de possibilidades, baseado em uma decisão de tamanho do mercado e porque eles já tinham familiaridade com os times europeus, justamente por essa proximidade ter ocorrido muito antes, no processo de desenvolvimento da molécula que acompanhava. As decisões foram tomadas apenas com as percepções internas."

\subsubsection{Gestão estratégica dos stakeholders}

Outro ponto que se observa no discurso dos entrevistados é a oscilação sobre como percebem as movimentações dos stakeholders. Em alguns momentos destacam a mudança 
comportamental de tomada de decisão, especialmente nos agrupamentos corporativos no setor privado de saúde (as chamadas operadoras verticalizadas), em outros repetem o valor da molécula para o posicionamento junto a estes. Ainda que a empresa relatada tenha processos estruturados de monitoramento dos stakeholders, eles não são observados em uma perspectiva ampla, mas principalmente sob a ótica da molécula. Adicionalmente, ainda não é clara a estratégia de construção de valor compartilhado - o que, além da molécula, pode trazer benefícios para o todo e não somente para o estágio de compra e utilização do medicamento.

Entrevistado 01D: (sobre aplicativo Brasil e aplicativo Global) "Eu não vi uma conexão entre o negócio e o que estava sendo entregue. Eu vi que surgiu uma ideia de alguém que queria inovar e vendeu essa ideia com um discurso 'vou escalar essa ideia para as outras afiliadas e vamos ter um aplicativo'. Em nenhum momento eu percebi que ficava claro o real ganho para a empresa. Se dizia assim um ganho para a sociedade médica como um todo, de que aqueles resultados poderiam ajudar nos estudos e nas avaliações para futuros pesquisadores, mas para a empresa em si, o que aquilo gerava valor? $O$ que aquilo gerava de negócios?”

Entrevistado 01B: “A gente não senta para conversar com o Ministério da Saúde como empresa, para apresentar portfólio, discutir as áreas de interesse federal, as áreas de interesse estadual. A gente não faz isso. Definir corporativamente estratégias de incorporação e levar soluções amplas para a mesa de negociação"

Adicionalmente, o monitoramento dos stakeholders não dá origem a uma estratégia clara e propositiva de abordagem destes. Ao contrário, funciona como um olhar em retrospectiva de reações destes às decisões quanto ao ciclo de vida do produto.

Entrevistado 01C: “A gente tende, dentro da farma, a querer soluções gigantes. No começo, fizemos um grande investimento em geração de demanda, mas não tinha reembolso do ministério. $O$ investimento deveria ter sido feito em gerar incorporação, e ai precisaríamos acionar um grupo menor de médicos"

Entrevistado 01D: "Para mim, a força está na política, é onde a gente pouco explora, porque, mesmo quando você está falando de paciente, onde que o paciente influencia? Na política. Então, um país como o nosso, que tem um sistema universal, que é via governo federal, a força é na política, e é algo que a gente entende muito pouco ainda, porque tem preconceito. A gente deveria ter estruturado uma equipe de engajamento 
político, da mesma forma que a gente tem médico-científico, a gente tinha que ter uma equipe politica, assim como empresas de outros setores fazem”

A falta de estratégia clara no gerenciamento dos stakeholders se reflete também na relação com a Matriz. A dificuldade em demonstrar valor nas inovações locais é apontada como um incômodo pelos entrevistados, da mesma forma que a falta de suporte por parte da liderança sênior. Esse contexto cria um ciclo de atividades em que a filial é cobrada por gerar resultados para as moléculas lançadas ou em lançamento em um novo cenário, mas é pressionada a entregar mantendo a previsibilidade dos momentos anteriores.

Entrevistado 01A: "Uma solução de alcance global precisa considerar um número muito grande de variáveis que impactam no desenvolvimento, na entrega, na segurança do que se propõe. E, neste caso (aplicativo Global), era preciso que alcançasse mercados de maior impacto. Sabíamos que o Brasil estava pronto e tinha interesse, mas não era prioridade inicialmente"

Entrevistado 01B: "Aí é a briga de poderes entre os países e a visão da Matriz sobre os países. Esse caso foi muito clássico, eles não priorizaram o Brasil. Eles queriam que fosse um país da Europa, eles queriam que, quem fosse vanguardista no aplicativo Global, fosse um dos países mais tradicionais para eles. O Brasil foi despriorizado mesmo, por falta de alguém para bancar a filial dentro desse debate. E aí vem o jogo político do peso dentro da organização, de você ter uma pessoa para bancar o país, e puxar essa força"

Entrevistado 01F: (sobre a definição pelo aplicativo Global) “Eu acho que tem um ponto que a gente fala pouco no nosso dia-a-dia que são as conversas difíceis. Eu acho que a gente tem uma experiência e uma rápida leitura de quando uma coisa pode dar certo ou pode não dar certo, porque a gente conhece o nosso mercado e tudo mais. Eu acho que, às vezes, o Brasil opta por não tomar uma decisão de falar 'não', porque tem uma visão submissa à Matriz. Então, assume uma postura de não questionar, como: 'ah, eu não acredito muito, eu não acho que vai, mas eu vou aceitar, né? Os caras são nossos chefes'. Às vezes não sei se é por um interesse de um dia estar na Matriz, mas opta por manter um bom relacionamento, ao invés de detalhar as condições para implementação no país"

Outro ponto importante é a dimensão do monitoramento dos stakeholders atualmente conduzido. Embora a estrutura da empresa permita estabelecer processos de acompanhamento 
dos stakeholders, estes são dirigidos para o ciclo de vida dos produtos, não para definir a estratégia de abordagens aos grupos de interesse ao longo da jornada dos pacientes, ou com o foco na sustentabilidade do sistema, como um todo. Na prática, resulta que, quando sobreposto à jornada do paciente, este mapeamento mostra apenas uma parte do comportamento e leva a interpretações eventualmente limitadas do cenário, em alguns momentos, inclusive, enviesando a interpretação do posicionamento dos clientes a partir da própria visão.

Entrevistado 01E: (sobre o lançamento do aplicativo Global) "Não vi, em nenhum momento, uma preocupação dos médicos com relação à validação das informações ou sobre aprovação regulatória. Eles não têm uma preocupação com isso. Eu acho que o regulatório, a preocupação é nossa, não é deles, eles não se preocupam com isso, como já vi em algumas apresentações também, como eles não se preocupam com farmacovigilância, para ficar reportando e tudo mais. Eles querem tocar as vidas deles da forma que for mais fácil possivel. Querem só clinicar."

Entrevistado 01B: (sobre as tentativas de incorporação de reembolso) "Para começar, a gente não sabe quais são as coligações políticas dos partidos, das pessoas envolvidas na tomada de decisão. A gente não conversa sobre isso nas áreas de negócio. A gente acreditava muito em um sistema que estava na mão de relações governamentais e isso é um conhecimento que ficava fechado em silo. E esse é o tipo de coisa que é tão estrutural do negócio que todo mundo tinha que saber"

Entrevistado 01F: “A gente ainda está falando que é customer centric, mas na verdade a gente ainda pensa ao redor do produto - ou ao redor de um produto que a gente vai lançar ou ao redor de um produto que a gente já tem, não tem essa separação de tentar procurar um novo modelo de negócio, um modelo de viabilizar financeiramente outras oportunidades junto aos clientes. Isso também dificulta as inovações”

Por fim, com a análise focada na jornada do produto e não na do paciente, as interações entre os diferentes stakeholders e, principalmente, novos atores passam despercebidas pela empresa. Oportunidades de inovação além da molécula surgem diretamente na relação entre o ecossistema de inovação e clientes, ou entre agentes públicos e clientes e mesmo entre diferentes clientes. 


\subsubsection{Transformação digital e armadilha do sucesso}

O caso 01 mostra que a empresa tem dificuldades em lidar com outros modelos de inovação. Ainda quando oportunidades além da molécula são identificadas, resultam em conflito interno pela tomada de decisão. A superação desses conflitos, no caso analisado, se dá pela decisão de conduzir a nova oportunidade a partir dos mesmos processos utilizados para desenvolvimento de fármacos. É o movimento definido por Sitkin (1992) como a complacência provocada pelo sucesso.

Entrevistado 01E: Houve um conflito interno na filial, mas nunca com a Matriz. Tentouse romper o modelo para fazer uma solução além da molécula que fosse local, mas não chegamos a uma definição do recurso. Aí surgiu a opção do aplicativo Global. Não era a mesma coisa, não ia ser específico para a necessidade do paciente brasileiro. Mas dava para encaixar. Aí a liderança sênior optou por esse procedimento. Ninguém imaginava que ia se arrastar por quase três anos.

Essa predisposição ao reforço do investimento na propriedade intelectual reforça, também, o viés da armadilha do sucesso na avaliação de risco pela empresa. Não necessariamente a análise de riscos é dirigida pelo montante a ser investido, mas pelo distanciamento da visão tradicional - quanto mais a opção de inovação se afasta da molécula, ou dos processos bem-sucedidos anteriormente, maior é a aversão.

Entrevistado 01E: "Por exemplo, no caso do aplicativo Brasil, era uma solução simples, pequenas atividades para o paciente interagir e reportar o estado de saúde. Então, assim, entender até aonde seria possível lançar um MVP e evoluir a partir de um teste real, sem riscos para os pacientes, para não perseguir o mesmo fluxo tão demorado de investimento de projetos grandes, que é a cultura da empresa”,

Entrevistado 01F: "É um argumento difícil de defender. Culturalmente, por causa do modelo de estudo clínico - fase um, fase dois, fase três - um contexto em que só libera o produto depois que está super testada a segurança do medicamento, gera essa insegurança e medo de testar alguma coisa em menor proporção, que é digital. É difícil conseguir mostrar para a empresa que o risco é baixo, muitas vezes, e de fazer esses testes de mercado" 
De acordo com os líderes entrevistados, os ciclos de processos são repetidos naturalmente para os lançamentos de novas moléculas. Por essa razão, também, não há modelos de desenvolvimentos de serviços e produtos além da molécula. Não havia, no período do caso estudado, revisão do modelo de negócios especificamente pela filial, cabendo essa definição à Matriz. As definições locais focam em questões mais operacionais, como calendário comercial, abordagem promocional, estrutura logística.

Sem um processo de revisão de oportunidades de inovação e com um modelo de atuação definido de maneira "top-down” pela Matriz, os líderes entrevistados se dizem sentir sem autonomia para tomada de decisão pela inovação além da molécula. Na visão destes, contradizer as diretrizes estabelecidas - e tradicionalmente bem-sucedidas - significa assumir para si os riscos, envolvidas questões de carreira, principalmente. As decisões, dessa forma, são restritas à maneira de implementar o modelo que, retrospectivamente, apresenta constantes resultados positivos.

Entrevistado 01B: (sobre o conflito na definição de implementar o aplicativo Brasil) "Porque senão fica aquela coisa de 'ah, tenho uma ideia aqui', mas, tudo bem, qual é o business case? Como é que você vai... você entra em um ciclo, né? Nem a empresa estrutura um modelo de investimento em criações locais, que era a discussão na época, nem os funcionários têm um incentivo da liderança, não tem nem, na maioria dos casos, suporte para propor a solução local. E os funcionários também não saem do lugar comum, né? Porque aí é uma outra situação. Okay, tudo bem, eu tenho uma outra ideia aqui, mas eu também preciso gerenciar a minha carreira, né? Se a empresa está me dizendo que a Matriz já está fazendo...”

Entrevistado 01C: "Pessoalmente, eu decidi não investir em algumas iniciativas de marketing repetidas. Quando acreditava que não ia trazer resultado, não quis fazer, não fiz. Mas você tem que aguentar o estômago de ficar sendo pressionado pelo seu entorno que não tem a mesma visão. E não fez diferença nenhuma, mas você tem que pagar esse preço. Nem todo mundo está disposto a pagar por isso. No caso de inovações além da molécula, a gente patrocina a ideia e alguém pode questionar, te pôr na parede e falar 'Por que você pôs tanto dinheiro nisso?'. Eu banco, mas a maioria não banca, porque isso põe em xeque a sua empregabilidade também. É muito cruel essa dinâmica, então a maioria das pessoas não arrisca, não arrisca mesmo." 


\subsection{ANÁLISE DO CASO 02}

A empresa descrita no caso 02 é uma startup brasileira, atualmente dirigida por três jovens sócios. É uma empresa de tecnologia que tem em um aplicativo de ePRO (relatos eletrônicos de resultados pelos pacientes, na sigla em inglês) seu principal produto/serviço, que é oferecido por meio de parcerias com serviços de saúde (hospitais, clínicas, seguradoras) e indústrias farmacêuticas para otimizar a comunicação entre médicos e pacientes e, por consequência, impactar positivamente o tratamento. Também oferece outros serviços tecnológicos para estes clientes, como se descreverá a seguir.

\subsubsection{Descrição do caso}

Pouco tempo após completar 17 anos, o Entrevistado 02A viu sua mãe ser diagnosticada com uma doença de alta taxa de mortalidade. O tratamento, de alto custo, poderia ser conduzido pelo SUS, mas ocorreria em uma cidade distante, onde estava o centro de excelência da rede pública naquela área terapêutica em especial. Para a família, de baixa renda, era a única alternativa disponível, ainda que significasse traslados intermunicipais a cada consulta, exame ou intervenção clínica necessária.

Durante o tratamento, uma preocupação recorrente para a família era o distanciamento da equipe clínica. Sem acompanhamento entre os agendamentos, como lidar com eventuais reações aos medicamentos? Como identificar novos sintomas oriundos da evolução da doença e, principalmente, a urgência com a qual deveriam ser tratados? As hospedagens e internações compartilhadas com outras pacientes fizeram com que o Entrevistado 02A percebesse que a situação não era uma limitação do caso da sua mãe, mas uma realidade vivida por muitos outros pacientes. Dado o contexto da saúde pública, centros de excelência em determinadas áreas terapêuticas são concentrados em regiões de significância epidemiológica regional. Em torno destes, inclusive, se formam pequenas comunidades de suporte a pacientes em trânsito pousadas, serviços de alimentação, etc.

Após alguns meses de tratamento, o falecimento da mãe intensificou o questionamento sobre o acompanhamento clínico. Quais fatores tinham impactado negativamente os resultados do tratamento? Teria tido algum impacto no processo de tratamento se as informações sobre evolução da doença tivessem sido acompanhadas em um intervalo menor de tempo? Então um 
estudante na área de saúde, Entrevistado 02A decidiu redirecionar sua linha de pesquisa para os chamados PRO (Patient Reported Outcomes ou Resultados Reportados pelo Paciente, na sigla em inglês).

Sua ideia era buscar uma alternativa que permitisse reduzir o tempo entre o eventual surgimento, ou evolução, de sintomas e o relato destes para a equipe clínica. Decidiu, então, desenvolver a primeira versão do seu aplicativo - doravante denominado aplicativo C02. Uma solução simples, em que o paciente registrava as variações dos sintomas ou reações adversas ao tratamento e este gerava um arquivo, em formato PDF, para compartilhamento com o médico ou qualquer outro integrante da equipe clínica (enfermeiro, farmacêutico, fisioterapeuta, cuidador, etc).

Cerca de um ano depois da criação da primeira versão do aplicativo, ainda limitada à função de compilar sintomas, durante um dos mais importantes congressos médicos do mundo, referência na área terapêutica alvo do aplicativo C02, foi apresentado um estudo que demonstrava impactos positivos no tratamento de pacientes que utilizavam soluções digitais de PRO (chamados de ePRO). O artigo, publicado em um journal científico e apresentado durante o congresso, foi um dos primeiros a demonstrar, cientificamente, ganhos reais em resultados clínicos do uso de aplicações digitais durante o processo de tratamento.

A demonstração científica de benefícios associados ao registro e reporte dos sintomas por parte dos pacientes, foi um importante elemento de alavancagem para a empresa no mercado de aplicativos de saúde. Embora o ritmo de adoção de ePRO no mercado como um todo ainda fosse lento, a exposição reputacional começou a abrir portas para a startup com diversos stakeholders da saúde, como hospitais, clínicas, seguradoras de saúde e até mesmo indústrias farmacêuticas. Na mesma época, a empresa receberia seu primeiro aporte financeiro, para contratar programadores que desenvolvessem novas funcionalidades.

O primeiro aporte veio de um investidor que se identificou com a história do projeto também havia perdido sua mãe para a mesma doença. Embora não tivesse um volume grande de recursos para investir no projeto, decidiu que também se juntaria ao Entrevistado 02A para desenvolver a solução e transformar a ideia em um negócio. Na visão dos sócios, era a hora de montar um modelo que permitisse escalar a solução e atrair mais clientes corporativos e pacientes para o aplicativo.

O aumento da exposição causada pelo artigo científico abriu uma série de portas para a startup. Aumentou a aceitação da solução por parte da comunidade médica, dos prestadores de 
serviço de saúde (hospitais e clínicas) e da indústria farmacêutica. Os clientes, no entanto, tinham interesses que iam além da lista de sintomas para controle. Farmacêuticas, por exemplo, pediam por funcionalidades que impactassem na adesão aos tratamentos prescritos. Hospitais e clínicas buscavam funcionalidades de monitoramento que incluíssem reações diretas e indiretas dos tratamentos - efeitos adversos e variações de humor, por exemplo.

Para encontrar um campo de desenvolvimento comum, os sócios começaram a basear a busca por soluções em suas próprias histórias. Nesse caso, para dar coerência ao desenvolvimento da aplicação e gerenciar os crescentes pedidos dos clientes, passaram a pesquisar a jornada do paciente da área terapêutica que trabalhavam como prioritária. Muitos dos pontos já eram conhecidos por eles, pela vivência que tiveram no tratamento de suas mães. Mas, para fazer das soluções um negócio escalável, estabeleceram uma metodologia própria para compreensão dos passos desta jornada, desde o momento anterior ao diagnóstico até após o tratamento medicamentoso.

A estruturação de uma metodologia para compreensão da jornada do paciente foi um passo importante na resposta da empresa às necessidades do mercado. $\mathrm{O}$ desenvolvimento de novas funcionalidades e o relacionamento com demais stakeholders seria definido a partir desta base. Também seria um delineador da cultura da empresa, então nascente, em relação à resposta às oportunidades de negócio. A intenção era que a jornada do paciente fosse o campo de busca por novas oportunidades e, ainda, o ponto de convergência com potenciais clientes.

A ida ao mercado, naquele momento, assumiu uma perspectiva diferente. Enquanto os números de médicos e pacientes usuários do sistema seguiam crescendo e, por consequência, seguiam surgindo oportunidades de parcerias de desenvolvimento com hospitais, os clientes corporativos ainda mostravam dificuldades para incorporar as tecnologias aos seus processos. Estas parcerias geravam, naquele momento, ao mesmo tempo, clientes da versão inicial do aplicativo, meios para testar novas funcionalidades e fonte de financiamento para a empresa. Novas funcionalidades se juntavam à ideia inicial da lista de sintomas - um diário completo de tratamento, check in no serviço de saúde e uma área de conteúdos educativos, por exemplo.

Em busca de aproximação com clientes corporativos, a empresa começava a lidar com conflitos inerentes às primeiras etapas do crescimento. Entre os sócios surgiam divergências entre aceitar todos os projetos de desenvolvimento propostos pelos parceiros ou seguir apostando na visão que tinham de entregar uma solução que abrangesse toda a jornada dos pacientes. De perfis diferentes, um biólogo, o outro administrador, tinham dificuldades em 
compreender seus papeis e conciliar diferentes ideias. As aproximações com empresas de grande porte - especialmente as farmacêuticas, planos de saúde e redes de hospitais - seguiam com travas. Por mais que os potenciais clientes demonstrassem interesse em integrar, de alguma maneira, a solução da empresa aos seus processos, a burocracia e as restrições regulatórias dos parceiros faziam crescer as barreiras.

A aproximação com os hospitais para desenvolvimento conjunto da solução parecia, naquele momento, ser um caminho importante para o seguimento da empresa. Primeiro, pelo princípio parecido de atuação, com foco na jornada do paciente. Com objetivos semelhantes, o diálogo fluía mais fácil. Segundo, porque também acrescentava conhecimento sobre o sistema de saúde para os jovens sócios, que até então só o conheciam como familiares de pacientes e agora atuavam como empreendedores no setor.

Com o rol de parceiros que havia desenvolvido até então, em especial três hospitais de São Paulo, Rio de Janeiro e Minas Gerais, a empresa passou a dedicar recursos nas oportunidades para desenvolver novos serviços, complementares ao produto original, sem, no entanto, perder o foco de entregar soluções que impactassem a jornada do paciente. Em colaboração com os clientes early adopters, desenvolveu modelos de suporte aos serviços de saúde que adotaram o aplicativo para o registro de sintomas - central de atendimento a pacientes, painel de monitoramento para médicos, programas de suporte a pacientes, treinamentos para equipes multidisciplinares.

Neste momento de definição, no primeiro ano após o aporte do segundo sócio, a empresa recebeu a oportunidade de ingressar em uma das mais importantes incubadoras de saúde do Brasil, mantida por um importante hospital do setor. Meses depois, o próprio hospital decidiria por fazer um aporte na empresa e assumir o papel de investidor. Ao final deste mesmo ano, alcançaria o ponto de equilíbrio.

A estruturação dos processos e a profissionalização que vieram a cargo do processo de incubação começaram a construir um diferencial importante na atuação da empresa. Primeiro porque deu origem a um roadmap claro de evolução do aplicativo. E, segundo porque, em torno dela, abriu as portas para o desenvolvimento de um rol de serviços que aproximaram a startup dos clientes corporativos e reduziram a resistência nos processos de interação com estes. Ganhando maturidade em relação à compreensão dos movimentos do setor, a empresa passou a montar uma estrutura que, adicionada à disponível para o aplicativo, suportou o passo seguinte da expansão da empresa. 
Em meio aos novos serviços que surgiram no período destaca-se a capacidade da startup se organizar de maneira ágil para atender a demanda dos clientes. A decisão de manter o desenvolvimento de produtos atrelado a necessidades surgidas do estudo da jornada dos pacientes permitiu à startup atender a estas oportunidades agregando inteligência ao aplicativo C02, ainda seu principal produto. Também ajudou a equilibrar os conflitos que surgiam do desconhecimento da visão que os potenciais clientes e parceiros tinham sobre a utilização de tecnologia na saúde. A prestação de serviços a estes clientes, portanto, serve a dois propósitos: agrega conhecimento sobre a jornada do paciente e o setor de saúde, ao mesmo tempo em que financia o crescimento da empresa e seu principal produto.

Os dois aportes recebidos pela empresa e a expansão dos serviços oferecidos também deram condição de direcionar investimento para a estruturação da empresa. Em uma situação um pouco mais estável que nas fases anteriores, os sócios começaram a planejar os passos seguintes de expansão. Então com apenas seis funcionários, investiram em uma consultoria de cultura corporativa para que a visão que tinham sobre o desenvolvimento contínuo de soluções atreladas à jornada do paciente não fosse só da liderança, mas também de todos os colaboradores.

Ao mesmo tempo, começaram a expandir o número de colaboradores, agregando, também, um grupo maior de profissionais de saúde para garantir assertividade das soluções. No modelo atual de gestão da empresa, todos os colaboradores contratados - independente da área de atuação - recebem uma fração da empresa. Desta forma, são chamados a contribuir para o desenvolvimento de soluções diferenciadas em suas respectivas áreas. Também recebem capacitação sobre a visão da empresa, sendo treinados para atuar com o foco na jornada do paciente.

Durante a crise provocada pela pandemia de COVID-19, a empresa viu seus clientes enfrentando grandes dificuldades. Enquanto o setor de hospitais privados, principalmente, perdia faturamento devido à suspensão consultas, exames e cirurgias eletivas, a empresa entendeu que era a hora de se demonstrar um parceiro disponível. Em conjunto com um de seus principais clientes, um grande hospital privado de São Paulo, implementou um módulo de teleconsultas no aplicativo C02, expandindo a solução, cobrindo cada vez mais etapas da jornada do paciente. Em contrapartida, viu seu número de clientes e o faturamento crescer no período. 
O crescimento experimentado neste período alavancou a ampliação da estrutura e a atratividade da empresa. Mesmo durante a crise provocada pela COVID, receberam o maior aporte financeiro até então, vindo de um fundo de venture capital. Outros dois médicos, especializados na área terapêutica alvo do aplicativo C02, também decidiriam juntar-se ao grupo de investidores da startup. Com o recurso, a empresa pretende investir na expansão da estratégia comercial e na personalização da jornada dos pacientes dentro do aplicativo C02.

\subsubsection{Gestão da inovação}

A análise do caso 02 mostra que o processo de inovação inicia pela busca de uma resposta necessidade específica dos sócios. Ao identificar que a necessidade se repete em outros grupos semelhantes de pacientes, os sócios passam a buscar uma resposta que esteja em uma alternativa ainda não desenvolvida. Não há naquele momento, um modelo estruturado de identificação de oportunidades de inovação, nem mesmo de desenvolvimento de novas funcionalidades para o produto; parte da reflexão da experiência própria dos sócios.

Entrevistado 02A: "Minha primeira ideia foi abrir um laboratório de biotech, porque eu estudava isso, para poder fazer testes genéticos a preço acessível para a população, para ajudar no diagnóstico precoce. Sabia de várias tecnologias que estavam sendo desenvolvidas fora do Brasil, com a saliva, com o sangue, e o meu estudo na faculdade era para detecção precoce de câncer. Só que, quando eu vi o custo dos equipamentos, eu pensei: 'eu não consigo fazer isso hoje' e também entendia que ninguém ia confiar aqueles muitos milhões a mim. Aí eu fui estudar a jornada do paciente com câncer e, eu vou acabar voltando na minha mãe. Mas, assim, eu morava longe do hospital. Quando a minha mãe passava mal, a gente não podia levar ela no pronto-socorro da cidade, a gente ia viajar com ela. O problema dela era o problema de vários outros pacientes"

Entevistado 02B: “Acredito que é super genuíno pensar em como eu gero mais oportunidades para melhorar a qualidade de vida do paciente. Então quando eu vejo que tem medicamento que custa 30 mil reais, 40 mil reais, tem drogas que custam isso em dólar, né? E é muito difícil para um paciente do SUS ter acesso a esse tratamento. Poxa, saber que a minha mãe tomou remédio de 13 reais enquanto existem medicações 
de 39 mil reais, 3 mil vezes maior valor, isso me choca um pouco e me faz querer dar acesso e oportunidade para que as pessoas mais pobres tenham acesso às mediações"

A alavanca de crescimento da empresa, no entanto, se dá a partir do momento em que os sócios compreendem que o modelo de busca de oportunidades de desenvolvimento e evolução do produto inicialmente proposto deveria se basear essencialmente na jornada do paciente. Ainda não há, naquele momento, um desenvolvimento da Inovação ou mesmo mapeamento de oportunidades. Há, contudo, uma clara visão de onde deveriam partir as perspectivas de inovação da empresa. A referência não seria o próprio produto ou a reposição de perdas por obsolescência deste. A definição de que os movimentos de inovação deveriam emanar da jornada do paciente cria uma alavanca para estruturação de um modelo próprio de identificação de oportunidades, baseado fundamentalmente nas necessidades dos pacientes e por extensão dos clientes que atuam como intermediários.

Entrevistado 02A: "A identificação de oportunidades para mim no setor de saúde começa sempre pela perspectiva do paciente. Eu entendo que o paciente tem uma jornada que é só dele. Eu entendo que esse paciente tem uma jornada que vai dele ser um indivíduo normal, uma pessoa com hábitos ruins, ter a doença, ser diagnosticada tardiamente, ter um pré-tratamento. Então acho que é baseado muito na jornada do paciente e na necessidade do paciente, a identificação de oportunidades parte daí e, a partir daí a gente entende quais são os stakeholders envolvidos naquele ponto da jornada em específico. Acho que isso tem muito de mim de como entender a jornada do paciente e propor serviços"

Entrevistado 02A: "Eu acho que os novos produtos e serviços, estão respondendo a um movimento de aglutinação. O que é a coisa mais próxima do que eu faço? O que eu posso fazer que é parecido, sem que eu perca ofoco? Nesse sentido, construir um novo módulo porque ele traz mais valor, ou como a gente dá sentido às funções, à funcionalidade do produto como um todo, acho que é um desafio que vivemos agora. Integrar todas as funções para, de fato, ver a jornada do paciente como uma e todas as funções do aplicativo estarem conectadas, não serem features isoladas"

Por ser uma empresa em processo de desenvolvimento e estruturação, os recursos para busca de inovação são escassos. Da mesma forma não há referência entre os sócios de como proteger os processos de criação produtos. A falta de referências claras de metodologias mais estruturadas fragiliza o processo de inovação. Isso porque expõe a empresa ao risco de repetidas 
vezes recorrer a um processo de tentativa e erro. Também há uma fragilidade na proteção das inovações já implementadas posto que o caminho de lucratividade com a solução não passa pelo registro da propriedade intelectual, como nas grandes farmas.

Entrevistado 02B: "No passado, fomos plagiados por um potencial parceiro. Eles pegaram o nosso aplicativo e fizeram outro igualzinho, com todas as funcionalidades. Durante 6 meses a gente conversou, fiz entrevista com eles, eles chegaram para falar com a gente. Tive mais de uma reunião em que eles falaram 'vamos trabalhar juntos'. Então, assim, é complicado. Quando eu falo plágio, é porque até os bonequinhos eles plagiaram, foi num nível de tudo é igual"

Entrevistado 02A: "Erramos muito. Os primeiros desenvolvedores que trabalharam conosco... a gente não sabia, não tinha como saber se eles eram bons, então erramos, contratamos errado. Gente que não entregou, que deu trabalho, mas ficamos calejados. Conhecemos mais profissionais, que ajudaram a achar outros, e hoje temos um time"

Uma vez que a empresa não busca o registro e consequente proteção da proteção intelectual após o lançamento do aplicativo, a opção para manter a competitividade é buscar a inovação constante dos serviços e modelos de negócio. Assim, definir um fluxo de inovação baseado em uma referência de jornada teve um papel importante nos resultados alcançados. Da mesma maneira abordagem a mercados mais tradicionais ou empresas que tem a sua realidade marcada por restrições regulatórias abriu portas uma vez que coloca em contraste os processos de inovação desses setores.

Entrevistado 02B: "Pensamos em um caminho de pequenas novas soluções, e também um caminho de disfunções, o que a gente tem que fazer que é muito disruptivo. O que a gente tem que fazer que a gente não faz hoje e que é muito legal fazer. Acho que a gente está entendendo mais onde a gente pisa. A gente está começando a trabalhar agora o desenvolvimento de um modelo preditivo para uma doença específica. Prever quais são as variáveis que levam o paciente ser hospitalizado, para ver se é possível evitar essa internação"

Destaca-se ainda no contexto da empresa um cenário de escassez de recursos que é próprio da realidade de uma startup. Não há um fluxo grande e contínuo de recursos financeiros. A inovação é, portanto, uma resposta inserida no dia-a-dia como metodologia de posicionamento e modelo de negócios. Como é próprio do segmento digital, no entanto, as soluções são fáceis de copiar ou reproduzir e, portanto, demanda da empresa um 
posicionamento mais amplo que ofereça diferenciação nesse contexto. O sucesso do produto é determinado pelo constante fluxo de inovação incremental combinada com criação de novas linhas de faturamento, além das inovações implementadas na nascente estrutura corporativa.

Entrevistado 02A: "Eu penso na inovação de curto prazo e a inovação de longo prazo. E aí pensando em diferenciais competitivos para criar barreias, para criar tanto benefício para os pacientes quanto ganho para a marca, a empresa, sabe? Consolidação de posição com outra empresa. Acho que uma coisa que facilitou foi o fato de que eu não conhecia, eu sou de fora. Eu sou, no bom sentido, um outsider da saúde. E eu tinha muito claro o propósito pelo qual eu estava fazendo o que eu estava fazendo"

Entrevistado 02B: Na primeira versão o produto era só um gerenciador de sintomas e a ideia era basicamente que o médico visse aquele relatório em PDF. Validamos que ele tinha algum valor para uma área de medicamentos, e depois para uma área de conteúdo com uma indústria farmacêutica. Fizemos, então, uma área de conteúdo. Depois um diário mais amplo, com informações dos medicamentos. O painel de dados para as equipes médicas vem de estudo, de literatura, entender como os médicos viam as informações. Agora a gente olhou para uma ideia de check-in. Estas respostas vêm de observação do mercado. A gente mapeou a jornada, identificou o problema. O que é esse problema de fato? E aí, como a gente pode resolver esse problema?"

Outro ponto importante é o incentivo à assunção de riscos por parte de todos os colaboradores da empresa. Em apenas três anos de existência formal, a empresa saiu de dois para 22 funcionários. Esse período, especialmente durante a fase de incubação e suporte corporativo, desenvolveu uma estrutura de gestão e remuneração dos funcionários pela criação de soluções de negócio. Como dito anteriormente, os funcionários estão progressivamente sendo recompensados com partes da empresa e, portanto, remunerados para tal, o que alavanca a criação contínua de inovações implementadas ao longo do tempo.

Entrevistado 02A: "Tudo que a gente faz tem que ser pensado no paciente. Às vezes a pessoa nem é de saúde e nem quero que seja, porque aqui dentro só vai entender sobre paciente e entender a jornada, porque é o que a gente faz. Então isso tem que ser trabalhado muito e isso é manifestado sempre. É manifestado, por exemplo, quando toda reunião de time começa com uma história de impacto, começa com a história de um paciente que a gente ajudou naquelas semanas." 
Entrevistado 02B: “A linha é reconhecer quem entrega valor e quem quer estar com a gente em longo prazo. Queremos remunerar quem está manifestando valores e gerando valor para a empresa. As pessoas são avaliadas aqui em uma matriz de performance e cultura. É ideal que a pessoa esteja lá no canto direito superior. Essas pessoas que ficarem ali muito tempo é quem vão ser os sócios. Se está entregando bem, é aderente à cultura e quer estar aqui, queremos que seja sócio, que vista a camisa."

\subsubsection{Gestão estratégica dos stakeholders}

Como uma empresa pequena, a startup ainda não tem todos seus processos definidos e documentados. Parte disso é o que ocorre com o monitoramento dos stakeholders. Embora monitorados e acompanhados constantemente, este movimento não faz parte de um processo formalmente estruturado, o que, no passado, resultou em frustrações para a empresa. No discurso dos entrevistados é possível compreender que esse mapeamento é compreendido por eles como parte do processo de posicionamento e relacionamento comercial da empresa.

Entrevistado 02A: "Temos um relacionamento muito mais próximo com médicos e com gestores de hospital do que com outras grandes empresas, por exemplo. Eu gastei muito tempo tentando conhecer as pessoas que iam ser meus clientes e criar relacionamento com elas, e criar relacionamento com as startups da incubadora, também”,

O que se mostra um diferencial importante nesse contexto é a dimensão na qual está incluída a relação com os stakeholders. Posta sob a visão da jornada do paciente, essa relação é dimensionada no potencial de criação de valor compartilhado para entrega de soluções eficazes para o sistema. Desta estratégia é que surgiram, por exemplo, a criação de novas linhas de faturamento que permitem o financiamento cruzado da expansão do aplicativo C02. A partir da compreensão de como o interesse dos diferentes agentes se organizam ao longo desse processo, a startup passou a flexibilizar o desenvolvimento e a evolução do seu produto para permitir a criação de valor para os parceiros.

Entrevistado 02A: "A gente vive em um sistema de desconfiança, né? No sistema de saúde existe uma desconfiança da fonte pagadora, que é a operadora de saúde, com a indústria. Quem pode se posicionar no meio, coletando os dados, e mostrando e sendo uma ferramenta para ter risco compartilhado? E depois enviar essas informações para 
um dossiê que vai para a ANS, ajudar na incorporação desse medicamento no rol das operadoras? Um outro mecanismo que a gente poderia utilizar para a pré-aprovação no SUS, por exemplo. É uma oportunidade de ajudar a todos porque é dado de mundo real. Então eu sempre penso na jornada do paciente e como a gente pode oferecer mais serviços"

Entrevistado 02B: "Eu acho que o sistema de saúde hoje, ele opera na desconfiança. Isso é muito ruim. O sistema de saúde opera num sentido de quem nenhum player confia no outro, que não confiam no SUS. E isso muito é ruim para o paciente, porque um sistema de desconfiança mútua é um sistema onde você se questiona o tempo todo. Será que é o melhor para o paciente? Será que ele está, de fato, interessado? Qual é a agenda oculta por trás daquela ação? Eu vejo com muita tristeza essa desconfiança e buscamos transitar entre os agentes mostrando que queremos desenvolver soluções que estejam presentes na jornada do paciente colaborando para todos"

Importante ressaltar que, dado o seu porte, a empresa não tem impacto suficiente para, sozinha, criar movimentações entre os stakeholders. Assim, ainda que esse contexto não permita uma estratégia agressiva na relação com estes, a abordagem de valor compartilhado ao longo da jornada do paciente ajuda a empresa no seu próprio crescimento - não apenas financeiro, mas no aprendizado contínuo sobre os movimentos do próprio setor.

Entrevistado 02B: "Não tenho um monitoramento sistêmico, mas a observamos muito claramente as movimentações internacionais e nacionais dos produtos. Então eu enxergo muito o que as redes de clínicas fazem. Acompanhamos as principais indústrias farmacêuticas, operadoras de planos de saúde e empresas que entendemos que temos que estar de olho. Hoje, vejo, por exemplo, uma movimentação muito grande das indústrias de aparelhos de radioterapia e as empresas farmacêuticas de comprarem startups, ou de ampliar a presença no setor digital”

Entrevistado 02A: "Com base no que sabemos do mercado, negamos trabalhar com duas instituições até agora. Uma indústria farmacêutica não quisemos trabalhar porque a proposta condizia pouco com nossos valores. Foi a primeira vez que nossa cultura empresarial pesou mais que uma oportunidade de negócio. Seria um ótimo faturamento, mas não correspondia aos nossos princípios"

O impacto é que, com uma aproximação sem imposição de valores, é bem vista e bem recebida por potenciais parceiros. Não há, ainda, resistência à empresa em si. Por outro lado, o 
estágio de aprendizado ainda incorre em ônus para empresas, ao lidar com empresas que não necessariamente compartilham da visão de criação de valor compartilhado.

Entrevistado 02A: "Quando me relaciono outras indústrias, vejo que existem embates corporativos. Tinha um projeto que a gente estava desenvolvendo que eu queria fazer parceria com uma associação de pacientes. O projeto quase não foi para a afrente porque isso gerou um conflito com a área responsável na indústria, que se sentiu ofendido, e aquilo gerou um problema com o time de digital, que também não sentiu contemplado e, de repente, começou uma guerra interna com outro projeto. A politicagem interna quase matou a startup porque a tomada de decisão tem que passar por vários líderes, tem uma baita política, e nem sempre a decisão é pela construção conjunta”.

\subsubsection{Transformação digital e armadilha do sucesso}

Por ser uma empresa nascida já em um contexto digital, a empresa do caso 02 é parte do grupo que está promovendo a transformação digital, e não necessariamente ameaçada por ela. Por outro lado, isso também significa que opera sob um modelo de inovação incipiente, sem barreiras claras para novos entrantes e sem a proteção que um registro de patente oferece, por exemplo. Por isso, é demandada a continuamente identificar novas oportunidades de inovação e coloca-las para teste no mercado, sob o risco de ser superada antes mesmo de lançar uma nova funcionalidade. Com isso, há a demanda por um fluxo contínuo de novas soluções dentro do aplicativo $\mathrm{C} 02$ e paralelamente a ele para cobrir a necessidade de desenvolvimento constante.

Entrevistado 02A: "A primeira versa do produto foi feita por amigos. Eu fiz na camaradagem, para testar e validar o MVP. E eu não tinha muita preocupação se estava estruturando bem, porque eu precisava validar aquele negócio, então você tem que pensar rápido, agir rápido, todas essas expressões são super batidas, mas elas de fato são mantras que devem ser seguidos. Eu errei no início, de ser imaturo e achar que esses mantras não eram funcionais e negar um pouco o meu lado cientista de hipóteses. Quando eu voltei a incorporar hipóteses que eu queria testar naquele intervalo de tempo, e começar a sempre pensar em hipóteses, acho que as coisas começaram a avançar mais rápido" 
Sob essa perspectiva, o caso da empresa destaca um ponto fundamental no cenário atual do mercado: a capacidade de adaptação ágil às mudanças do mercado. $\mathrm{O}$ impacto gerado pela pandemia de COVID é uma mostra interessante e, embora em uma dimensão inédita, ilustra o potencial de reação em cenários incertos. Com os clientes perdendo faturamento, talvez não fosse o momento de insistir no aprofundamento da utilização do aplicativo C02, desenhado para uma área terapêutica específica. Nem assim, no entanto, a empresa optou pelo afastamento dos clientes, pelo contrário, sem abrir mão de seu princípio de atuar junto à jornada do paciente, passou a desenvolver soluções paralelas ao seu produto core que suportassem as necessidades imediatas dos parceiros.

Entrevistado 02A: "Eu gosto do método, cientista. Apesar de ser uma pessoa não processual, valorizo o método, por isso que a gente está trazendo pessoal de web research, design thinking, para poder pensar design de serviços, para poder ajudar. Não sou apaixonado pela solução, sou apaixonado pelo problema, e isso faz com que a gente não fique apegado àquela coisa, a gente está disposto a resolver o problema. A gente tem que investigar com as pessoas que tem esse problema. E o Brasil é muito grande, então a gente tem que explorar país inteiro. Montamos um time que roda o país para entender quais são os problemas de cada região para a gente conseguir construir produtos e serviços de alcance nacional"

Essa movimentação também é um sinal de uma empresa totalmente em processo de construção - de estrutura, de cultura, de posicionamento. Não abre mão do princípio que está na base de sua fundação, de desenvolver-se com o foco na jornada dos pacientes, mas também não se limita aos processos já estruturados. Nesse sentido, o sucesso é um objetivo futuro, não uma referência passada. Até pelo fato de que não conhece referências vinculativas de sucesso, uma vez que as pequenas conquistas se acumulam em torno da definição de base, não dos procedimentos estabelecidos. Importante ressaltar que o sócio identificado como Entrevistado 01 não possuía experiência profissional antes de iniciar o projeto do aplicativo C02 e o sócio identificado como Entrevistado 02 não chegou a ocupar cargos de liderança antes de juntar-se à empresa.

\subsection{ANÁLISE DO CASO 03}


O caso 03 trata de uma biotech, uma startup de ciências biológicas, focada em novas abordagens de P\&D por meio de análise computacional. Ao mesmo tempo em que trabalha no desenvolvimento de moléculas próprias, executa serviços de consultoria para suportar projetos de pesquisa que aumentem a assertividade na seleção de moléculas candidatas. Se define como uma das primeiras startups brasileiras a negociar processo de licenciamento de um fármaco nacional antitumoral com uma empresa multinacional. Fundada em 2014, tem largo histórico de relacionamento com institutos de pesquisa.

\subsubsection{Descrição do caso}

Pela maior parte de sua carreira no setor corporativo, o Entrevistado 03B trabalhou com pesquisas na área farmacêutica. Por cerca de 13 anos, inclusive, teve a oportunidade de atuar em indústrias brasileiras do segmento. Após duas passagens por grandes empresas nacionais, havia trabalhado em projetos chamados de inovação, que visavam estabelecer laboratórios nacionais de P\&D. Encontrava-se, então, no que define como uma situação "confortável”: em posição de liderança, estável, bem remunerado e reconhecido. Mas se sentia insatisfeito. Nas suas palavras, não via naquelas iniciativas a busca pela disrupção, pela inovação radical, mas, sim, por iniciativas dedicados a criar ambientes de reprodução de moléculas (o que o Entrevistado 03B define como " $m$ e too", os genéricos), mais como uma iniciativa de marca do que efetivamente para criar novos produtos locais.

Ao longo de sua carreira, até pela natureza de sua atividade, havia buscado se manter próximo à academia. Acreditava, então, que na universidade encontraria talentos para agregar às pesquisas no ambiente corporativo. No mercado de trabalho, no entanto, encontrava dificuldades para manter esses talentos transitando entre os dois ambientes. Nas empresas em que atuava no setor, via a dificuldade de acolhimento a esses profissionais e também não encontrava abertura para incluir pesquisadores de fora nos projetos internos de desenvolvimento.

Em 2010, reencontrou uma colega que havia conhecido no doutorado. Ela, após alguns anos de trabalho em institutos de pesquisa, também tendo atuado em indústrias farmacêuticas, havia voltado à sua cidade natal, e iniciado um negócio próprio, investindo em uma farmácia de manipulação. Falaram sobre suas carreiras, as oportunidades na indústria, o desejo mútuo de desenvolver projetos de inovação radical e os caminhos das farmacêuticas no Brasil. 
Conversaram sobre a falta de uma molécula de grande sucesso comercial desenvolvida no país. Combinaram de pensar em projetos que poderiam desenvolver em conjunto.

Anos depois, começaram discutir a possibilidade de abrir uma empresa que trilhasse um caminho diferente da inovação radical em fármacos no Brasil. Não tinham condições financeiras para um projeto desse porte, que demandava um grande investimento em estrutura física e equipe - como uma grande farmacêutica - e, ao mesmo tempo, com grande risco de seguirem sem conseguir desenvolver moléculas. Decidiram, então, manter o propósito da inovação radical, mas inovar no modelo de negócios. Diferente da abordagem tradicional do segmento, que aposta na posse integral e exclusiva da propriedade intelectual, focariam na criação de valor compartilhado a partir desta.

Para tanto, começaram a investir na criação de modelos de planejamento racional utilizando métodos avançados de modelagem molecular para triagem e descoberta de novos fármacos. O processo computadorizado emula a estrutura da molécula e desenvolve protótipo do seu mecanismo de ação, permitindo visualizar, simular e interpretar sistemas interrelacionados. Embora ainda não signifique o desenvolvimento completo de um fármaco por meio de simulação computadorizada, o processo evolui na testagem de diferentes candidatos, buscando ampliar a assertividade na escolha daqueles que seguirão para o desenvolvimento in vitro, muito mais caro, e, por consequência reduzir o custo total do processo.

Daí por diante, com uma molécula candidata robusta e validada no processo criado pelos pesquisadores, a empresa passaria a trabalhar com parceiros, que assumiriam os custos de desenvolvimento da molécula, e dividiriam o licenciamento da propriedade intelectual. Os outros pilares de serviços oferecidos pela empresa, de Síntese química e Avaliação farmacológica, viriam a cargo do crescimento das oportunidades no relacionamento com o setor.

O modelo de atuação, no entanto, ainda não se equilibrava do ponto de vista financeiro. Era preciso uma estrutura de profissionais mais robusta para suportar o desenvolvimento das pesquisas. Manter uma equipe altamente capacitada e experiente, no entanto, teria um custo elevado. Novamente, a alternativa era repensar os modelos consagrados do setor. Ao invés de montar uma equipe fixa e dedicada exclusivamente às iniciativas próprias, construir uma rede de pesquisadores, contratados para colaborar projeto a projeto, e estruturar um modelo de gestão do conhecimento. 
Àquela altura, a segunda sócia, Entrevistado 02A, já havia deixado sua farmácia de manipulação. O montante da venda seria importante para iniciar a nova empresa, mas não cobriria todos os custos. Os sócios começaram, então, a acompanhar os editais dos programas de fomento à pesquisa em pequenas empresas. Com uma entidade química candidata para tratamento oncológico, conseguiram aprovação do primeiro projeto de P\&D no Programa Pesquisa Inovativa em Pequenas Empresas (PIPE), da Fundação de Amparo à Pesquisa do Estado de São Paulo (FAPESP). Na primeira fase do programa, com duração de nove meses, a empresa comprovou a viabilidade tecnológica do produto em desenvolvimento. Na fase seguinte, seguiu para a pesquisas de comprovação de segurança para, posteriormente, avançar o estágio de desenvolvimento. No mesmo ano, também seria aprovada para um programa de incubação tecnológica em uma universidade.

Mesmo com o bom desempenho nas chamadas de fomento e o seguimento no desenvolvimento da entidade candidata à fármaco, a empresa ainda enfrentava dificuldades. Com a molécula ainda distante da fase de licenciamento em que efetivamente renderia dinheiro, era preciso encontrar fontes alternativas de financiamento. Assim, os sócios passaram a estruturar uma linha de serviços de pesquisa que poderiam prestar a outras indústrias, inclusive farmacêuticas - até mesmo potenciais concorrentes. A opção foi de não distanciar os outros agentes do setor, mas estabelecer credibilidade por meio da capacidade científica.

O modelo de atuação em desenho demandava uma estrutura que oferecesse flexibilidade e agilidade para responder às necessidades dos projetos próprios e de eventuais serviços para terceiros. Assim, foi preciso reativar a rede de contatos dos tempos de pesquisa e ampliar relações com outros órgãos que auxiliassem na identificação e concretização de oportunidades. Neste momento, a empresa daria início a uma sequência de parcerias de Cooperação TécnicoCientífica. Duas destas teriam papel essencial nos próximos passos da startup: com a Fundação da Faculdade de Medicina da Universidade de São Paulo (FFMUSP) e com dois Institutos do Hospital das Clínicas da Faculdade de Medicina da USP (HCFMUSP) - Instituto do Câncer do Estado de São Paulo (ICESP) e Instituto de Radiologia (InRad).

No processo de desenvolvimento das oportunidades, a empresa entendeu que precisava considerar diversos fatores para seguir com uma entidade química potencial. Para ser uma oportunidade de negócios, sua necessidade precisava se justificar a partir de uma perspectiva mais ampla, que considerasse a epidemiologia e a mortalidade da doença alvo, mas também a necessidade real do sistema a partir do contexto do paciente. O que este trabalho define como 
jornada do paciente passou também a ser tema das interações com os hospitais parceiros como um dos fatores de captação de oportunidades.

Foi assim que se expandiu a atuação na primeira molécula em desenvolvimento a chegar ao estágio de testes in vitro, que abriu a oportunidade de parceria com uma empresa europeia para a continuidade do desenvolvimento do tratamento. Desta mesma forma nasceu a percepção de que havia jornadas de pacientes não cobertas com tratamentos específicos - medicamentos veterinários, dando origem a uma nova linha de negócios. Nesta mesma perspectiva, a empresa celebrou acordo de cooperação científica com a Faculdade de Medicina Veterinária e Zootecnia (FMVZ) da USP para colaboração na criação de medicamentos veterinários. Pouco tempo depois, nova aprovação de PIPE-Fapesp, desta vez para estudos de tratamentos para animais.

A ativação da rede de relacionamento com institutos, hospitais, universidades, laboratórios e indústrias iniciou um modelo distinto de estruturação da equipe. Com a flexibilidade para contratar os pesquisadores projeto a projeto e uma rede de colaboração extensa e com profundo conhecimento em saúde, a empresa ganhou agilidade para responder às demandas nascentes de demandas de terceiros, que passaram a dar estabilidade financeira para que a startup seguisse investindo no desenvolvimento de suas próprias moléculas.

Atualmente, ainda incubada, a empresa presta serviços de pesquisas para indústrias farmacêuticas brasileiras, institutos e laboratórios. O equilíbrio financeiro vem da prestação de serviços com estas entidades, fruto da flexibilidade do modelo de negócio e gestão. Seu mais novo projeto é transformar o acesso à rede de relacionamento com pesquisadores, que permite a flexibilização na estrutura de pesquisa, em um serviço oferecido a parceiros e clientes. A primeira molécula da empresa continua em via de desenvolvimento, na parceria com a empresa europeia, ainda evoluindo em testes clínicos. Outras entidades químicas candidatas também seguem em avaliação, tanto para tratamento humano como para veterinário, fruto do modelo de mapeamento de oportunidades estabelecido pela empresa. Para os sócios, segue o sonho de encontrar e desenvolver a primeira molécula brasileira de sucesso.

\subsubsection{Gestão da inovação}

O caso 03 se assemelha mais ao das grandes farmacêuticas dada a natureza da gestão da inovação. Por ser uma biotech, a empresa tem foco no desenvolvimento de pesquisas e criação 
de propriedades intelectuais. O que muda, principalmente, é a visão sobre o processo de inovação. Primeiro, pelo mapeamento de oportunidades, no qual a empresa cruza dados epidemiológicos com informações da jornada dos pacientes por meio de parcerias com hospitais e clínicas especializadas. Segundo, pela estrutura operacional. Como o modelo não se baseia na posse integral e exclusiva da propriedade intelectual, mas na criação de valor compartilhado entre diferentes parceiros, o que será discutido mais a frente, a equipe fixa é menor e pode ser ajustada de acordo com necessidades específicas de determinada pesquisa.

Entrevistado 03B: “Identificamos que, no Brasil e no mundo, o tumor de pulmão é o segundo mais importante em mortalidade. Além disso, olhamos para a problemática da doença em si impactando no mercado e na disponibilidade terapêutica, de medicação disponível. Aqui no Brasil, especificamente em São Paulo, temos parceria com o ICESP, o Hospital do Câncer, que trabalha essencialmente com o SUS e participa de trials clínicos. Por meio de convênios desse tipo, e também com a faculdade de medicina, o corpo clínico, na parte de oncologia clínica, trazemos como consultores nos nossos projetos científicos. Isso nos ajuda na tomada de decisão, do que vamos desenvolver, para impactar na cadeia final do sistema de saúde”

Entrevistado 03A: "Uma das riquezas potenciais da nossa empresa é o grupo de pesquisadores que temos para agregar a um projeto. Isso nos permite montar uma equipe para determinado projeto que é altamente qualificada. Nosso modelo de negócio nos permite manter uma estrutura pessoal muito enxuta. Toda a necessidade de custos é bancada pelo projeto e a estrutura fixa tem um custo muito baixo."

Entrevistado 03B: "Nos dois tipos de tumores que estamos trabalhando agora, tanto para a saúde humana, como para a saúde animal, as terapias disponíveis no SUS são bem antigas, e que, por isso, não têm tanta efetividade. Então, faz-se terapias combinadas e tem uma resposta que é okay para aquele tipo de doença e eleva o custo. Então partimos do tipo de problema a atacar e do tipo de resposta para isso. Hoje temos conversado várias vezes de estudar projetos outros tumores e iniciamos busca por alternativas importantes com pesquisadores do nosso grupo, justamente porque é um tumor que não é atendido de forma efetiva pelas terapias medicamentosas que aqui estão disponíveis. Então consideramos, sim, a efetividade do tratamento quando desenha um projeto para começar a abordagem da inovação radical. Se não a gente vai fazer o 'me too', que é o que o genérico e a indústria farmacêutica já fazem normalmente" 
É possível compreender, ainda, que o modelo foi desenhado para dar flexibilidade na entrega de projetos e serviços. Ainda que a empresa tenha clara visão de qual é seu core e onde pode entregar mais valor aos grupos de interesse, promove diversificação de serviços prestados com foco em manter sua principal linha de negócio. Assim, consegue direcionar pesquisas com mais agilidade para oportunidades que eventualmente surjam - é o caso dos estudos para produtos veterinários, por exemplo, área de pouco interesse para as indústrias farmacêuticas tradicionais, ou, ainda, pesquisas para o agronegócio.

Entrevistado 03A: "Basicamente, identificamos a oportunidade, que vem dos conhecimentos de toda a equipe, das competências de toda a equipe. A partir do potencial identificado, já estruturamos um planejamento de um a dois meses, definindo principalmente a questão de recurso, equipe, corpo de consultores. E isso é muito importante, porque vai agregar conhecimento, muitas vezes um conhecimento que a equipe mesmo não tem. A partir daí tem toda uma estratégia para fazer essa prospecção, essa captação desse conhecimento científico, e isso alimenta todos os nossos projetos"

Entrevistado 03B: "Nossa perspectiva inicial era atuar basicamente na área de saúde humana, mas também identificamos oportunidades de desenvolver projetos na área de saúde animal. Porque muitas vezes se adapta o uso humano para o animal. Mas, se a gente já tiver o foco no uso animal, de certa forma encurta o caminho. Além do que, os testes pra uso animal têm um custo mais baixo e podem abrir portas para a nossa empresa avançar na perspectiva de desenvolvimento de testes clínicos como um todo"

Entrevistado 03A: "Um exemplo, o instituto de pesquisa, o Butantan. Eu trabalhei no Butantan. Fui contratada pelo instituto por um tempo e trabalhei justamente nessa área da inovação, e lá eu fiz muitos contatos, eu participei de projetos maiores, com indústrias farmacêuticas. Esses pesquisadores mantemos contato até hoje $e$ desenvolvemos projetos juntos. Por conta de biodiversidade, temos uma outra parceria específica que começou em 2018. Ajudamos os parceiros na exploração de óleos essenciais, para vários tipos de ações farmacológicas e na área de agronegócio também."

Considerando o mercado brasileiro, a empresa também usa o modelo de mapeamento de oportunidades para criar diferenciação em relação às indústrias farmacêuticas brasileiras e também das filiais das multinacionais, pelo foco na inovação radical. Como o serviço core está 
no processo seletivo de moléculas, e não na produção efetiva, a empresa investe na descoberta de potenciais disrupções e não na inovação incremental de produtos. Ao mesmo tempo, não se desliga do segmento para se apresentar como uma alternativa qualificada para prestações de serviços de pesquisa.

Entrevistado 03B: "Hoje ouvimos sobre indústrias farmacêuticas nacionais grandes montado o próprio setor de desenvolvimento de novos fármacos. Isso a gente ouve falar de 10, 15 anos, mas que realmente tenha um lançamento que seja revolucionário, que tenha de uma inovação radical, não ouvi falar. Acredito que as oportunidades vêm muito daquilo que tem fora do país: pequenas empresas no ambiente propício conseguem desenvolver produtos de alta complexidade tecnológica e trabalham em conjunto ou são compradas por empresas maiores. Isso faz com que aquele produto chegue ao mercado, mas, dificilmente, na área farmacêutica, isso ocorre no Brasil. Aí vem a pergunta: por que, então, estamos atuando nessa área? Porque precisamos fazer aquele gol inicial, porque ai eu acho que a coisa deslancha."

A partir da fala dos sócios, é possível compreender que, para os pesquisadores, um desafio importante foi desenvolver uma estrutura de gestão de inovação que não se limitasse à atividade laboratorial. Ao mesmo tempo, que não se distanciasse do seu propósito original de ser uma empresa fundamentada nas pesquisas. Para tanto, pensaram em uma estrutura organizacional que valorizasse as parcerias de pesquisa, permitisse a montagem de métodos de trabalho diferenciados e flexibilidade para buscar o financiamento cruzado, com a prestação de serviços sustentando a busca pela inovação radical.

Entrevistado 03B: "Nosso desejo sempre foi de montar uma empresa de pesquisa e desenvolvimento, uma empresa de pesquisadores, para o desenvolvimento de novas moléculas. Mas pensando em uma empresa de $P \& D$ que consiga fazer projetos de inovação radical custa caro. E assim desenvolvemos um portfólio de serviços voltado basicamente para sobrevivência. Se não tivéssemos esses serviços, a gente ia quebrar. Sempre fui o que mais se preocupou com a questão de custo fixo. O nosso custo fixo tem que ser o mínimo para se não tivermos fluxo nos serviços, a gente não quebrar"

Entrevistado 03A: "A questão dos consultores (pesquisadores que vêm de outros institutos) é bem importante para nosso posicionamento também pela credibilidade. Quando precisamos complementar alguns ensaios, algumas tecnologias que não temos o domínio especificamente, precisamos nos organizar para ter na equipe consultores 
que ajudem a gente colocar os projetos para andar. E encontrar recursos, no caso dos assessores que vão avaliar a chamada. Temos que pensar em tudo isso na formação da equipe."

\subsubsection{Gestão estratégica de stakeholders}

O modelo de gestão da inovação adotado é fortemente baseado em uma estratégia de construção de valor compartilhado entre diferentes stakeholders. Ao longo do desenvolvimento da estrutura da empresa, os sócios perceberam que a posse integral e exclusiva da propriedade intelectual demandaria um investimento inviável para uma empresa no início da jornada. Assim, desenharam um modelo de desenvolvimento em que criam, continuamente, metodologias avançadas de pesquisa e recrutamento de moléculas até o ponto em que seguem o licenciamento do fármaco na transição das pesquisas in vitro para as pesquisas in vivo.

Entrevistado 03B: "O que vejo, em termos de parceria, é que não tem um projeto de inovação radical que não seja multidisciplinar. Não vamos conseguir chegar no nível que estamos pretendendo sozinhos. Acredito que a plataforma que estamos trabalhando (de conexão para ecossistema de inovação) vai nos ajudar como uma forma de seleção dos parceiros que vão nos ajudar. Essa é a pretensão, são os parceiros que vão nos permitir chegar naquele nível mais elevado, que apenas o especialista químico do mais alto nível ou do especialista me modelagem molecular."

Entrevistado 03A: "Temos parceria com uma empresa bem novinha, uma biotech, e os sócios são todos bioengenheiros e trabalham com automação. Tem muita sinergia com o que a gente faz e começamos a trabalhar juntos. Esses contatos são estabelecidos bem próximos e a incubadora também proporciona essas interações entre as empresas. Buscamos no sistema de inovação essa integração entre pesquisadores que participam de startups, e promovemos discussões entre esses novos negócios para proporcionar novas parcerias e outros negócios. O ambiente que trabalhamos é essencialmente esse: na parte acadêmica, instituto, incubadora."

Entrevistado 03A: "Essa relação também ocorre na nossa área de prestação de serviços. Nesse sentido, até pela estrutura que a gente conseguiu montar nesses últimos anos, quatro, cinco anos, para a gente é importante essa interação com os participantes 
deste universo até para vender o serviço nas áreas que nós atuamos; tanto na área de planejamento racional, a parte do que seriam as ferramentas virtuais para fazer essa modelagem molecular, principalmente. Então nesse sentido, essas interações dentro desse universo para a gente são importantes."

Como descrito anteriormente, o modelo prevê cooperação com agências de fomento, academia, pesquisadores, prestadores de serviço em saúde (hospitais e clínicas), farmacêuticas e agências regulatórias. Assim, o processo de monitoramento dos stakeholders e a consequente estratégia de abordagem é, em si, uma entrega no processo de desenvolvimento, uma vez que uma inovação bem-sucedida passa, necessariamente, pelo reconhecimento de valor pelos grupos de interesse e o envolvimento desses na realização das oportunidades mapeadas pela empresa.

Entrevistado 03B: "Estamos montando uma plataforma em que empresas de natureza inovadora, de inovação tecnológica possam participar de uma forma sinérgica. A ideia inicial é até voltada para essa questão de sobrevivência para que o meu cliente possa se interessar por uma prestação de serviços do meu parceiro. Dentro da incubadora, é impressionante que às vezes você não tem essa estruturação organizada, então a gente acaba sendo o núcleo de inovação. A gente está pretendendo ser um núcleo de inovação dentro de uma incubadora, dentro de um núcleo de inovação."

Além do foco na geração de valor compartilhado, o modelo de trabalho também apresenta uma configuração de compartilhamento de risco. Quando desenvolve um modelo próprio para as primeiras etapas da pesquisa farmacêutica, a empresa assume para si - e, por consequência reduz para o potencial parceiro - uma parte do risco, encaminhando para a continuidade da pesquisa candidatos mais aptos a se tornarem moléculas comerciais.

Entrevistado 03A: "No Brasil não temos essa cultura de inovação radical. Porque os projetos de inovação radical são projetos de alto risco e envolvem somas de dinheiro muito grandes. A indústria nacional ainda não se sente confortável para esse investimento com esse risco, trabalham prioritariamente com o reposicionamento da molécula - muda a apresentação ou acrescenta um uso. O que fazemos, então é tudo o que vem antes da fase clínica - até a comprovação da atividade e proteção da propriedade intelectual. Mas o cenário mesmo só vai mudar quando esses novos 
núcleos, essas novas startups, mostrarem resultados nesse desenvolvimento. Mas ainda estamos começando a caminhar e a gente precisa demonstrar que é possível"

Entrevistado 03B: "Trabalhamos com métodos alternativos de desenvolvimento, modelos in vitro que podem integrar o modelo humano o mais próximo possível. A migração do in vitro para o in vivo é a fase de mais risco no desenvolvimento e a parte investigativa corresponde de 20 a $25 \%$ de um projeto de inovação radical. Então, trabalhamos com métodos inovadores para ser mais assertivos na fase investigativa para minimizar o risco. Acho que a gente como startup, como empresa de inovação, tem a missão de mudar o cenário com nossas moléculas se tudo for bem, como tem ido até agora."

A capacidade de transitar entre esses diferentes agentes também coloca a empresa em uma condição favorável na obtenção do financiamento cruzado por meio do faturamento da prestação de serviços. Os sócios reconhecem, no entanto, que, hoje, a dependência dessa linha de faturamento pode ser um risco para a manutenção do modelo de gestão de inovação. Isso porque exige dedicação do time e investimento de tempo e recursos financeiros da empresa.

Entrevistado 03B: "Uma fonte importante é a verba de projetos de agências de fomento direcionados para serviços que vão ser contratados. É quase uma questão de sobrevivência, né? A gente não pode ficar só pensando em projetos voltados para a inovação radical, ainda mais projetos que a gente sabe que, se a gente ganhar dinheiro, vai ser daqui a alguns anos. Então tem esse aspecto a mais e tem a ver com uma relação ampla com os stakeholders, a gente quer prestar serviço para essas empresas."

\subsubsection{Armadilha do sucesso}

A longa experiência na indústria farmacêutica e as seguidas frustrações com a repetição de modelos e processos por estas empresas são apontados pelos sócios como motivos que os levaram ao empreendedorismo. O desgaste pelos projetos não realizados e pela falta de incentivo à inovação radical nas indústrias brasileiras deu a ambos a vontade de conduzir seus próprios caminhos e os colocou em busca de capital para realização dos planos, em um processo semelhante ao descrito por Pinchot III (1989), mas, nesse caso, com foco prioritariamente em verbas destinadas ao fomento à pesquisa e não no capital de risco. 
Entrevistado 03B: "A questão é que eu poderia ter ficado na indústria, estaria lá até hoje, em uma situação tranquila, talvez, ou até num posto de diretoria. Depois, a estagnação em determinada carreira ia acabar comigo, na verdade. A questão é que a gente está em um país que, para assumir um determinado risco dessa natureza é complicado. Quando acabei minha pós-graduação, fui para o Ceará como professor visitante. Depois eu tive a proposta de um laboratório, voltei para São Paulo, fiquei lá um tempo. Depois eu saí para montar consultoria, depois fui para a Bahia para fazer um projeto na universidade, que estava ligado a uma farmacêutica. E saí para montar minha empresa, meus projetos de inovação radical. Por que assumir esses riscos? Justamente para fazer alguma coisa que valha a pena. É o principal."

Entrevistado 03A: "Então é essa questão de propósito, de procurar outras cosias e querer sempre transformar para deixar um legado para as pessoas. A gente estuda tanto, todo mundo investe na nossa formação, porque tivemos bolsa. Temos essa obrigação de dar um retorno para as pessoas."

Nesse sentido, a percepção de risco também assume um papel distinto, posto que não envolve um recurso terceiro. Os entrevistados descrevem que todas as decisões, desde a saída da carreira acadêmica e da corporativa, até o investimento na compra de maquinário, são envoltas em alto grau de risco - primeiro, pela escassez de recursos disponíveis para os investimentos; segundo, pela incerteza do alcance de resultados, posto que não havia referência no Brasil de trabalhos dessa natureza e desenvolvidos a partir do modelo estrutural desenhado.

\subsection{DISCUSSÃO}

Respeitadas as diferenças, inclusive de porte, entre as empresas, a análise dos casos mostra paralelos importantes sobre a maneira como estas transitam entre os stakeholders no contexto atual da saúde no Brasil. Atuando no mesmo mercado, identificam oportunidades a partir de uma base distinta e, como consequência, respondem a elas em velocidades diferentes e com estratégias distintas. Mesmo em um cenário de alta complexidade e em constante transformação, a grande indústria farmacêutica ainda opta pelo isolamento e controle exclusivo da cadeia de valor de seus produtos, enquanto as startups se mostram mais flexíveis e abertas a construções colaborativas que agreguem valor para o sistema e para os parceiros. 
O primeiro ponto a ser observado com mais detalhe é a maneira como observam e atuam em relação à jornada dos pacientes. Acostumada a fornecer o medicamento e focar seus esforços na etapa de tratamento, a farmacêutica não expande sua atuação - ou mesmo sua avaliação para o todo da jornada do paciente. Resulta que iniciativas de inovação além da molécula, que possam agregar valor ao sistema, são rejeitadas ou enquadradas nos processos tradicionalmente estabelecidos.

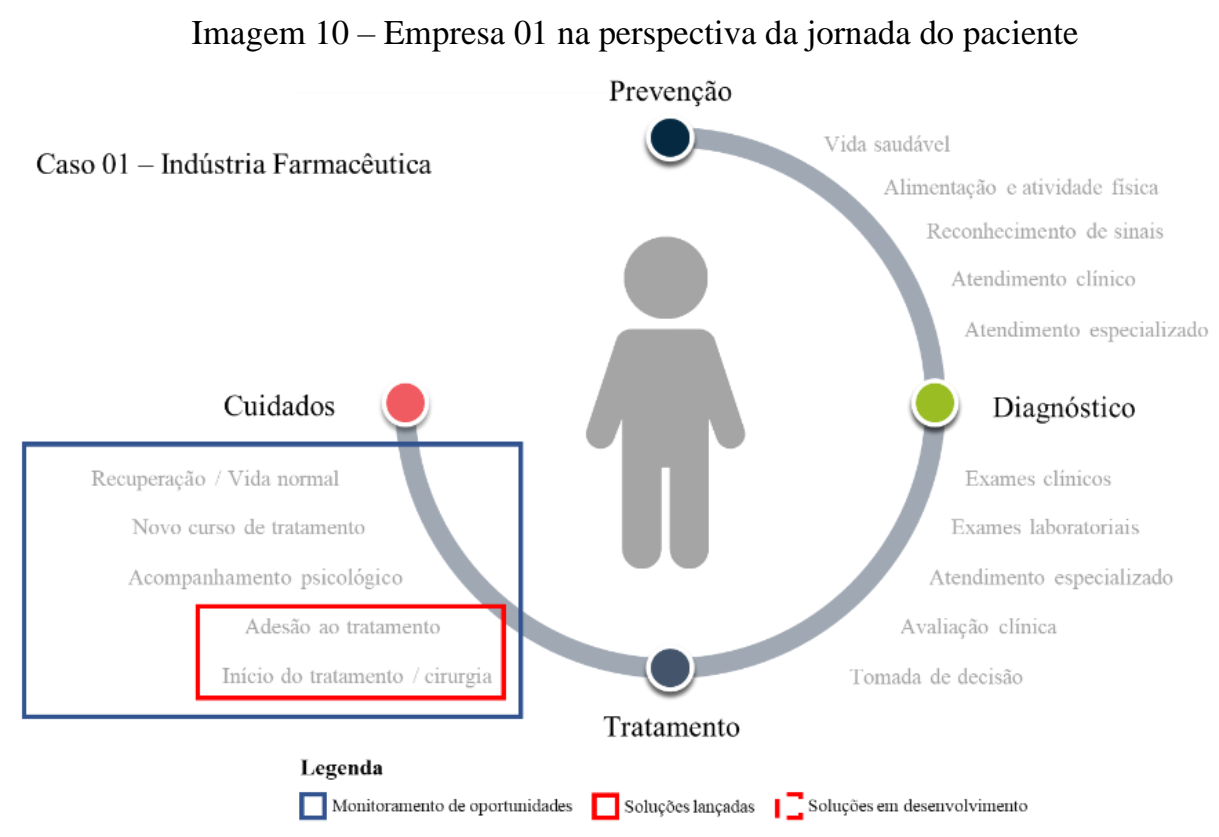

Fonte: Elaborado pelo autor

As startups, por sua vez, mesmo que com processos rudimentares, olham para um espectro maior das etapas, em busca de oportunidades para desenvolver inovações, enquanto a indústria farmacêutica se foca na etapa em que já tem extenso portfólio, ainda que com processos sofisticados. Natural que as razões que levam as startups a estes movimentos passam também pela necessidade de consolidação e crescimento rápido. Assim, buscam continuamente por oportunidades de abrir novas linhas de faturamento. 
Imagem 11 - Empresa 02 na perspectiva da jornada do paciente

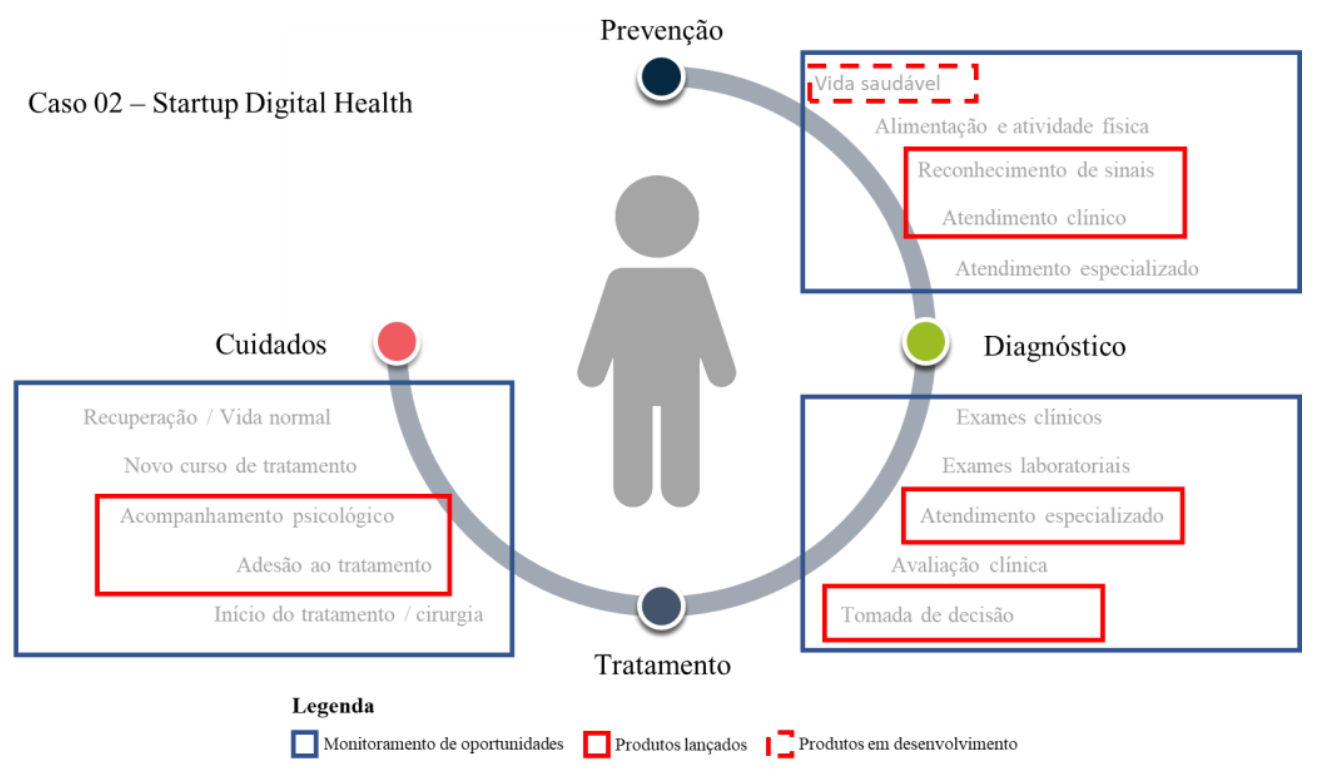

Fonte: Elaborado pelo autor

Ainda sobre o mapeamento de oportunidades e gestão da inovação, há uma percepção comum às três empresas de que há um impacto no setor decorrente da transformação digital da saúde. No entanto, difere bastante a interpretação sobre como este pode criar alavancas de negócio positivas. Para a empresa 02 , nativa digital, a aceleração tecnológica significa diretamente a possibilidade de ampliação de linhas de faturamento e conquista de clientes, ampliando a presença na jornada do paciente.

Imagem 12 - Empresa 03 na perspectiva da jornada do paciente

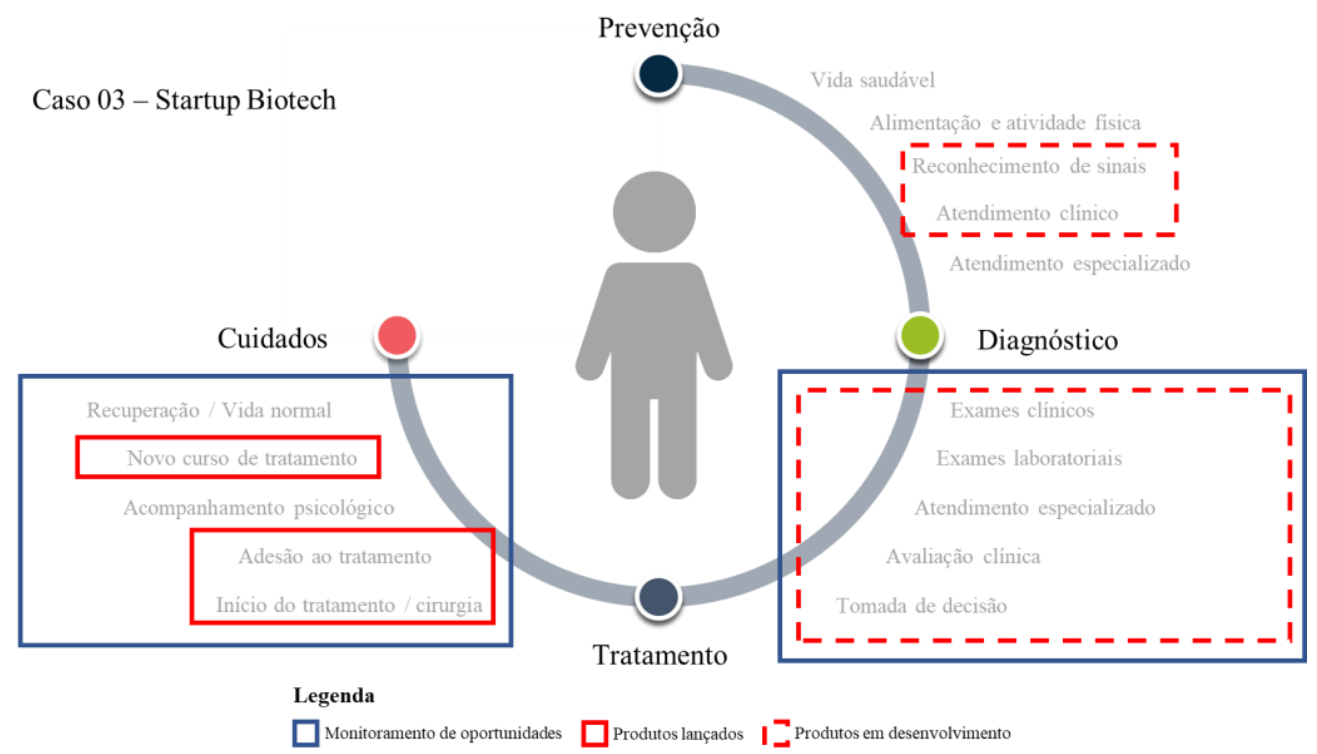

Fonte: Elaborado pelo autor 
Assim, enquanto as startups, nascidas em meio digital, têm facilidade para incorporar as novas tecnologias em seus produtos ou métodos de gestão, a grande empresa se move lentamente nessa direção, mesmo com a disponibilidade de recursos para investimentos, como se pôde ver no caso 01, com a tentativa de criação de um aplicativo para suporte ao tratamento.

Também impactam a agilidade na tomada de decisão e na implementação de iniciativas para atender as oportunidades identificadas. Quando estas são paralelas, ou mesmo complementares às atividades core das empresas, o tempo de reação é bastante diferente. A estrutura consolidada da grande empresa, acostumada a processos longos de desenvolvimento do produto, tende a buscar enquadrar a nova oportunidade nos seus procedimentos padronizados, o que resulta em conflitos internos e, em geral, lentidão na resposta à oportunidade. As startups, por sua vez, se organizam para responder rapidamente a essas novas chances de crescimento. A nascente estrutura é direcionada para isso, coordenando rapidamente a manutenção da atividade core.

Outro ponto importante é a estratégia de gerenciamento dos stakeholders. Enquanto os entrevistados do caso 01 ressaltam a existência de processos e modelos de monitoramento sofisticados, eles reconhecem a falta de tomada de decisão direcionada aos grupos de interesse. Em geral, as decisões partem de um movimento autocentrado que considera estas relações prioritariamente sob a perspectiva das necessidades da empresa e não do contexto geral. Também são restritas a stakeholders que tradicionalmente orbitam em torno da decisão de tratamento, mas não cobrem outros agentes que têm ganhado força ao longo da jornada do paciente - como as próprias associações de pacientes, agentes envolvidos no processo de reembolso (Ministério da Saúde, operadoras de plano de saúde) e mesmo agentes políticos.

Para as startups, em processo de consolidação no mercado, a abertura para criação de valor compartilhado é um movimento mandatório, uma vez que precisam dessas relações para estabelecer credibilidade com stakeholders externos. Sem os recursos e a estrutura das grandes empresas, no entanto, estruturam estratégias agressivas de gerenciamento dos stakeholders com foco excessivo no crescimento, o que, em alguns casos, passa uma preocupação estritamente comercial - a necessidade imediata se sobrepõe ao propósito da geração de valor compartilhado.

Um fator crítico é na avaliação entre os casos estudados é a armadilha do sucesso. As referências do sucesso passado são recorrentes nas falas dos entrevistados do caso 01, como guias contínuas das atividades - para lançamento de produtos, investimentos, tomadas de decisão, etc. Para as demais empresas, no entanto, o sucesso ainda é um objetivo futuro. Embora 
seja possível encontrar referências positivas no histórico das empresas - aprovação em rodadas de investimento / programas de fomento ou mesmo o fato de ambas terem alcançado o ponto de equilíbrio -, estes momentos ainda não são encarados como referências vinculantes que devem ser repetidas continuamente. Também porque, até o momento, são conquistas isoladas, não se tratando de sucesso constante.

Outro ponto diferencial é a percepção de risco. Entre os fatores limitadores provocados pelo sucesso, Sitkin (1992) ressalta a aversão ao risco pela diferença entre as alternativas do presente e os resultados do passado. Ainda que com maior capacidade de estrutura e recursos para assumir riscos, a grande empresa do caso 01 tem mais dificuldade em lidar com o risco de uma abordagem distinta aos sucessos do passado. Inclusive porque, sob a perspectiva corporativa, o desenvolvimento do produto já havia carregado uma série de riscos, pelo investimento assumido. Para as startups, essa avaliação é distinta, uma vez que a própria criação da empresa é um risco para os sócios. E, da mesma forma, também não há um volume grande de ativos em sob ameaça nesse momento da empresa.

A aversão ao risco como resultado da armadilha do sucesso também é um fator de destaque sob a perspectiva de carreira dos funcionários envolvidos no processo de tomada de decisão de inovação além da molécula. Para os entrevistados do Caso 01, em sua maioria ocupando posição de liderança em uma empresa multinacional, contradizer o procedimento bem sucedido no passado, independente de sua adequação à necessidade atual, é visto como uma escolha de risco pessoal, com impacto no desenvolvimento de carreira. Esta leitura atua como um limitador, inclusive, para coleta aprofundada de dados sobre a oportunidade de inovação.

Por outro lado, para os funcionários das startups, esta limitação na adoção de riscos acaba por ser um fator que os tira de companhias com este perfil. Três dos quatro entrevistados dos casos 02 e 03 tiveram passagens por grandes empresas antes de optar pelo investimento no próprio negócio - dois deles, inclusive, em indústrias farmacêuticas de grande porte. Para estes, a falta de espaço para o desenvolvimento de novos projetos de inovação foi o fator decisivo para a escolha pelo empreendedorismo. 


\section{CONCLUSÕES}

Para a construção da conclusão deste trabalho, serão considerados os objetivos primário e secundários, a questão de pesquisa, a revisão da literatura e o levantamento de campo. $\mathrm{O}$ objetivo principal aqui proposto foi identificar caminhos para inovação além da molécula no setor da saúde e observar de que maneira estes se contrapõem à tradicional gestão da inovação da indústria farmacêutica, focada no desenvolvimento e proteção de propriedades intelectuais.

Em primeiro lugar, é preciso ressaltar que este trabalho não busca se posicionar como uma crítica ao desenvolvimento de novas moléculas pela indústria farmacêuticas, mas, sim, avaliar por que, em um cenário progressivamente mais complexo para o lançamento e venda de novos medicamentos, em especial os de alto custo, as indústrias do segmento seguem insistindo nos mesmos processos executados há dezenas de anos. Desta forma, o estudo partiu de uma análise de cenário, demostrando a baixa aceitação por parte dos grupos de interesse aos sucessivos lançamentos de drogas cada vez mais caras.

A pesquisa de campo permitiu observar que algumas práticas adotadas por startups têm sido bem-sucedidas no relacionamento com stakeholders no segmento, em especial para o desenvolvimento de soluções além da molécula para o sistema de saúde. Primeiro, a busca pela compreensão da jornada do paciente em sua integralidade. Ainda que, em um primeiro momento, as soluções entregues não se estendam a todos os estágios de interação desta jornada, a compreensão do todo é um diferencial importante no relacionamento com os atores que orbitam em torno do paciente, uma vez que se configura como um ponto comum entre um conjunto diverso de grupos de interesse - hospitais, clínicas, médicos, governos, Ministério da Saúde, secretarias estaduais, familiares, cuidadores, associações de pacientes.

A jornada do paciente se torna, nas relações entre os diferentes stakeholders, um campo comum para o desenvolvimento de novas oportunidades, seja um aplicativo para acelerar o acesso ao tratamento, seja a triagem de moléculas para necessidades médicas específicas não atendidas atualmente pelo sistema, como demonstrado nos casos, ou seja, como uma oportunidade conjunta identificada e trabalhada pelos pares, não como um movimento imposto de lançamento de novos produtos da indústria para os pacientes. Como definem Freeman et al. (2018), "ver o mundo pelos olhos dos múltiplos stakeholders" para gerar valor ao sistema.

Importante ressaltar que, nos casos pesquisados, é possível observar que a visão da integralidade da jornada do paciente não surge como um movimento natural para as empresas, mas sim como um processo efetivamente estabelecido. Se na startup retratada no caso 02 essa 
visão vem das experiências pessoais dos sócios-fundadores, na empresa do caso 03 vem por meio de parcerias com os serviços de saúde que, com a visão da ponta do atendimento, e participando do desenvolvimento das pesquisas, passam a influenciar as tomadas de decisão.

Adicionalmente, outro direcionamento que se pode perceber a partir das entrevistas é a aceitação de riscos nos processos internos de inovação. Em relação ao caso 01, da indústria farmacêutica, é possível perceber que os riscos assumidos no desenvolvimento do fármaco consomem a abertura da empresa a novos modelos de abordagem ao mercado e aos tratamentos. Em paralelo, sem muito a perder, as startups retratadas nos casos 02 e 03 se dispõem a arriscar com iniciativas mais ágeis, menor tempo de lançamento ao mercado e disponibilidade para incorporar a visão dos demais stakeholders.

Da mesma forma, este trabalho estabeleceu como objetivo identificar barreiras internas nas indústrias farmacêuticas que se contrapõem à inovação além da molécula. A partir do caso 01 descrito, é possível perceber que há uma conjuntura de forte vínculo com os processos estabelecidos previamente, interpretados como responsáveis pela construção da história da empresa - a armadilha do sucesso, descrita por Kaufmann (2004). O quadro abaixo apresenta, a partir dos fatores potencialmente limitadores originados no sucesso passado, descritos por Sitkin (1992), barreiras identificadas no estudo do caso 01 para o avanço do investimento em inovação além da molécula.

Tabela 05 - Barreiras internas no caso 01

\begin{tabular}{|c|c|}
\hline Fatores limitadores (Sitkin, 1992) & Barreiras identificadas no caso 01 \\
\hline Complacência & $\begin{array}{l}\text { Ainda que o portfólio estivesse em processo de } \\
\text { erosão pelo término da proteção de algumas } \\
\text { propriedades intelectuais, a empresa tem } \\
\text { dificuldades em buscar outros modelos de } \\
\text { inovação, uma vez que há uma crença de que a } \\
\text { repetição dos processos anteriores cumprirá } \\
\text { naturalmente o papel de recuperar o sucesso } \\
\text { passado }\end{array}$ \\
\hline $\begin{array}{l}\text { Baixo nível de atenção e de busca por } \\
\text { informações }\end{array}$ & $\begin{array}{l}\text { A repetição de processos passados, como adotar } \\
\text { o padrão de criação de um fármaco para o } \\
\text { desenvolvimento de um aplicativo, sem a análise } \\
\text { da complexidade do problema atual limita a } \\
\text { tomada de decisão até que a situação chegue a um }\end{array}$ \\
\hline
\end{tabular}




\begin{tabular}{|l|l|}
\hline Aversão ao risco & $\begin{array}{l}\text { ponto alarmante de ruptura (como as seguidas } \\
\text { recusas na incorporação do medicamento) }\end{array}$ \\
\hline $\begin{array}{l}\text { Homogeneização de equipes, culturas, processos } \\
\text { e tomada de decisão }\end{array}$ & $\begin{array}{l}\text { Sem suporte da liderança, responsáveis pela } \\
\text { tomada da decisão não se expõe a decidir } \\
\text { sozinhos por um procedimento diferente do } \\
\text { padrão de sucesso estabelecido anteriormente }\end{array}$ \\
$\begin{array}{l}\text { Conflitos pela tomada de decisão pelo } \\
\text { investimento em inovação além da molécula são } \\
\text { rapidamente silenciados pela homogeneização da } \\
\text { cultura de aceitação do procedimento } \\
\text { padronizado }\end{array}$ \\
\hline
\end{tabular}

Fonte: Elaborado pelo autor

Pela análise, chega-se à conclusão que a maneira com que o sucesso passado é encarado na empresa transforma-o em um fator limitador do investimento em inovações e também de aprendizados decorrentes de novas iniciativas. Deixa de ser um objetivo para o futuro, se configurando como um vinculador ao passado, levando à repetição contínua de atividades sem uma análise concreta do problema que se precisa endereçar a cada momento.

Outro objetivo que este trabalho buscava identificar era a diferença no mapeamento de oportunidades surgidas a partir da gestão estratégica dos stakeholders. Observa-se pela comparação entre os casos que, ainda com processos de monitoramento de oportunidades estabelecidos em níveis de complexidade distintos, há uma questão importante relacionada à origem das oportunidades. Para a indústria do caso 01, é uma análise que parte de dentro para fora - da sua própria visão do processo de tratamento. Para as startups, inclusive porque não têm porte para liderar o segmento, as oportunidades vêm de fora, por uma questão de sobrevivência.

Ao mesmo tempo em que a inovação é uma prática para as startups, ela também é uma demanda do contexto de mercado em que estão inseridas. Isso porque, na maioria dos casos, as propriedades intelectuais dos serviços e produtos digitais não são protegidas por patentes ou copyrights. Tome-se o caso 03 como exemplo: enquanto desenvolve uma propriedade intelectual que será registrada e licenciada em conjunto com outra empresa, trabalha na estruturação e prestação de uma série de serviços ligados às suas capacidades específicas e que representam, atualmente, a maior parte do seu faturamento. Estes serviços não são registrados, 
até por uma opção financeira. Assim, é preciso que este modelo de atuação continue em evolução constante para que represente um diferencial para a companhia.

Desta forma, embora demonstrem mais agilidade para responder às demandas dos stakeholders, as startups precisam, continuamente, desenvolver novas soluções ou evoluir as atuais. O ciclo de vida do produto é curto e as barreiras para entradas dos competidores são praticamente inexistentes, expondo, inclusive, as inovações a cópias. A competitividade, no caso, vem da necessidade de evolução contínua, da diferenciação pela inovação incremental.

Por fim, sob a ótica de boas práticas que possam ser observadas pelas indústrias farmacêuticas nestes novos atores que começam a se destacar no relacionamento com o segmento da saúde, configuram-se algumas oportunidades que podem se transformar em caminhos para enfrentamento ao contexto descrito. Abaixo, propostas identificadas na construção deste trabalho que se apresentam sob esta perspectiva:

- Desenvolver relações com stakeholders que sejam baseadas na construção de valor compartilhado. Freeman et al. (2010) defendem que a oportunidade para mudanças na estrutura do sistema de saúde está na ênfase dos stakeholders do segmento em criarem riqueza total ("total wealth creation"). O modelo baseado exclusivamente na imposição de novas moléculas ao mercado traz uma proposta de ganho unilateral pela indústria, sem adicionar valor ao sistema como um todo, ampliando as resistências dos setores público e privado;

- Basear a criação de valor compartilhado na jornada do paciente. A criação de valor total ao longo da jornada do paciente - não apenas no estágio de tratamento - pode ajudar a encontrar pontos de interesse comuns com diferentes grupos de stakeholders;

- Estabelecer parcerias para troca de conhecimento com base não comercial. Buscar interfaces não comerciais com stakeholders que operam em outras etapas da jornada do paciente podem agregar conhecimentos que não estão presentes na empresa atualmente, favorecendo a construção de valor presente e futuro (FREEMAN et al., 2018);

- Sob a mesma perspectiva do desenvolvimento de parcerias para trocas de conhecimento, está a estruturação de programas científicos junto a laboratórios de pesquisa e universidades ligadas ao setor público. Já estabelecidos em outros países, inclusive, em alguns casos, na origem das matrizes das grandes indústrias farmacêuticas, estes modelos podem adicionar informações mais ricas sobre a jornada do paciente em 
mercados específicos ao mesmo tempo em que alavanca soluções para criação de valor para estas localidades. É possível observar, no relato do caso 03, experiências bemsucedidas nesta direção que, adicionalmente, ajudaram a empresa a desenvolver capacidades além da molécula;

- Uma mudança importante é a abertura para o ecossistema de inovação, acompanhada do compartilhamento de valor com estes agentes. Acostumadas a ter o controle de todo o processo de inovação, as farmacêuticas têm dificuldades para se relacionar com startups, incubadoras e aceleradoras, por exemplo. As experiências das empresas $02 \mathrm{e}$ 03 mostram que processos de construção colaborativa de soluções para a saúde, com compartilhamento do valor gerado ente os agentes, podem ser diferenciais de posicionamento no sistema;

- Estruturar programas de incentivo ao intraempreendedorismo fora dos laboratórios. A capacidade de encontrar soluções diferenciadas, bem como o desenvolvimento de novas linhas de faturamento e posicionamento em determinados mercados dependerá, no contexto apresentado, na capacidade de buscar alternativas novas para os problemas novos, não apenas repetindo o comportamento bem-sucedido do passado. Configura-se, então a oportunidade de desenhar, nas atividades desenvolvidas nas filiais (marketing e logística), programas estruturados para incentivar criação de soluções além da molécula dentro do ambiente corporativo, evitando que funcionários com características empreendedoras saiam da empresa para criar seus próprios negócios (PINCHOT III, 1989) e se tornem concorrentes, como descrito no caso 03.

\section{LIMITAÇÕES E CONTRIBUIÇÕES}

Embora haja uma extensa literatura sobre gestão de inovação, gestão de stakeholders e sistema de saúde, a maioria dos estudos sobre a indústria farmacêutica trata especificamente da inovação de produtos e gestão da propriedade intelectual. É possível notar, no entanto, especialmente em relação a artigos publicados a partir de 2018, um crescimento no interesse pela transformação digital na saúde e a relação com o segmento, a chamada inovação "além da molécula". A revisão teórica, no entanto, mostra que os debates ainda são incipientes. 
Dessa forma, é interessante notar que as intensas transformações ainda em curso na saúde podem dar origem a novos estudos sobre o setor como um todo e sobre o segmento farmacêutico em particular. Especialmente durante o período da pandemia de COVID, diversas indústrias farmacêuticas foram obrigadas a ampliar seus investimentos em tecnologias digitais em praticamente todas as etapas de sua operação, o que elevou os conflitos aqui descritos para níveis ainda mais intensos. É possível imaginar que algumas das discussões aqui iniciadas podem ser escaladas em novos estudos a partir dos próximos meses.

A distinção entre inovação global, a partir da matriz, e local, nas filiais, também é um tema que ganha relevância com a crescente restrição orçamentária em países em desenvolvimento como o Brasil. Em um ano como o de 2020 em que as prioridades governamentais foram alteradas pela crise global provocada pela pandemia de COVID, os investimentos em tratamentos de alto custo são intensamente questionados do ponto de vista de custo-efetividade, colocando em cheque a garantia de reembolso e consequente lucratividade das propriedades intelectuais. A gestão local de stakeholders a partir de inovações além da molécula pode ser um tema importante para avaliação futura sob o ponto de vista de posicionamento nos mercados e introdução de novas linhas de faturamento, como análise de dados em saúde ou soluções digitais para tratamentos.

Ainda que não fosse o tema central deste estudo, outra derivação de pesquisa que surge é o desenvolvimento de modelos de relacionamento entre grandes empresas e startups no atual cenário de saúde no Brasil. Embora as indústrias farmacêuticas ainda demonstrem ser um segmento fechado a determinados tipos de interação, a demanda por uma atuação transversal à jornada do paciente pode abrir oportunidades para uma interface mais intensa com startups do setor, auxiliando na criação de uma cultura de inovação além da molécula no setor.

Por fim, embora a análise da indústria farmacêutica no contexto atual da saúde apresente uma série de oportunidades, a relação entre o perfil conservador de um mercado consolidado e o foco da inovação apenas para o desenvolvimento de produtos parece se repetir em outros segmentos, considerando, evidentemente, as especificidades dos mercados. A armadilha do sucesso, nesse caso, pode ser objeto de um estudo mais amplos em empresas com esse perfil ou mesmo como startups em processo constante de crescimento lidam com essa perspectiva em sua estrutura em expansão. De qualquer forma, pode abrir uma linha de investigação similar para outros mercados, como o segmento automotivo, por exemplo. 


\section{REFERÊNCIAS}

AKKARI, A. C. S.; MUNHOZ, I. P.; TOMIOKA, J.; DOS SANTOS, N. M.B.; DOS SANTOS, R. F. Pharmaceutical innovation: differences between Europe, USA and 'pharmerging' countries. Gest. Prod. São Carlos, 2016, v. 23, n. 2, p.365-380.

ANVISA. Preços máximos de medicamentos por princípio ativo, para compras públicas. Disponível em http://antigo.anvisa.gov.br/documents/374947/6048620/LISTA_CONFORMI DADE_GOV_2020_10_v1.pdf/48d3d03b-efd5-49ed-bb69-b434b530e0be. Acesso em 03 jan. 2021.

ANWAR S.; CHOWDHRY, B.S.; PRASAD, R. Smart Pharma: Towards Efficient Healthcare Ecosystem. In: FRATU O., MILITARU N., HALUNGA S. (eds) Future Access Enablers for Ubiquitous and Intelligent Infrastructures. Fabulous 2017. Lecture Notes of the Institute for Computer Sciences, Social Informatics and Telecommunications Engineering, Springer, Cham, 2018, v. 241.

ARONSON, J. K.; FERNER, R. E.; HUGHES, D. A. Defining rewardable innovation in drug therapy. Nature Reviews, 2012, v. 11, p. 253-254.

BASTOS, V. D. Inovação Farmacêutica: padrão setorial e perspectivas para o caso brasileiro. BNDES Setorial, Rio de Janeiro, 2005, n. 22, p.271-296.

CHEN, Z.; HUANG, S.; LIU, C.; MIN, M.; ZHOU, L. Fit between Organizational Culture and Innovation Strategy: Implications for Innovation Performance. Sustainability 2018, 2018, V.10, n. 10, p. 2-18.

DE ALBUQUERQUE, G. M. Integração Vertical nas Operadoras da Assistência Médica Privada. In: EnANPAD 2006 - $\mathbf{3 0}^{\circ}$ Encontro da ANPAD. Salvador, 2006.

DELOITTE. 2019 Global life sciences outlook. Disponível em https://www2.deloitte.com/ content/dam/Deloitte/global/Documents/Life-Sciences-Health-Care/gx-lshc-ls-outlook2019.pdf. Acesso em 30 mar. 2019.

DIMASI, J. A.; HANSEN, R. W.; GRABOWSKI, H. G. The price of innovation: new estimates of drug development costs. Journal of Health Economics. New York, 2003, v. 22, n. 1, p. 151-185. 
DOS SANTOS, E. C.; FERREIRA, M. A. A indústria farmacêutica e a introdução de medicamentos genéricos no mercado brasileiro. Nexos Econômicos, Salvador, 2012, v. 6, n. 2, p.95-120.

DRUCKER, P. Inovação e espírito empreendedor: práticas e princípios. 2. ed. São Paulo: Pioneira. 1987.

EMANUEL, E. J. Choice and Representation in Health Care. Medical Care Research and Review, 1999, v. 56, supplement 1, p. 113-140.

EMIS Insights. Brazil Pharma and Healthcare Sector 2017/2021. Disponível em: https://www.emis.com/blog/brazil-pharma-healthcare-sector-20172021. Acesso em 30 mar. 2019.

ENGEL, J. S. Accelerating Corporate Innovation: Lessons From The Venture Capital Model. Research Technology Management. 2011, p. 36-43.

ESPEDAL, B. The success trap in organizational learning: Cognitive and political explanations. Unpublished Manuscript, Norwegian School of Economics and Business Administration, 2002.

FERREIRA, F. G.; POLLI, M. C.; OSHIMA FRANCO, Y.; FRACETO, L. F. Fármacos: do desenvolvimento à retirada do mercado. Revista Eletrônica de Farmácia. Goiás, 2009, v. 6, n. 1 , p. $14-24$.

FREEMAN, R. E. The stakeholder approach revisited, in: Zeitschrift für Wirtschafts- und Unternehmensethik, 2004, Jg. 5, Heft 3, p. 228-241.

FREEMAN, R. E. The Stakeholder Concept and Strategie Management. In: Strategic Management: A Stakeholder Approach.). Cambridge University Press. Cambridge, 2010. p. 31-51, doi: 10.1017/CBO9781139192675.005. Acesso em 27 de dez. de 2020.

FREEMAN, R. E.; HARRISON, J. S.; HICKS, A.; PARMAR, B.; DE COLLE, S. Stakeholder Theory: The State of the Art. Cambridge University Press. Cambridge, 2010.

FREEMAN, R. E.; HARRISON, J. S.; ZYGLIDOPOULOS, S. Stakeholder Theory: Concepts and Strategies. Cambridge University Press. Cambridge, 2018.

GIL, A. C. Como elaborar projetos de pesquisas. São Paulo: Editora Atlas, $4^{\mathrm{a}}$ edição. 2002. GIL, A. C. Métodos e Técnicas de Pesquisa Social. Editora Atlas, 6a edição, São Paulo, 2008. 
GRABOWSKI, H. Patents, Innovation and Access to New Pharmaceuticals. Journal of International Economic Law. Oxford University Press. 2002, p. 849-860.

GRZEGORCZYK, T. Managing intellectual property: Strategies for patent holders. The Journal of High Technology Management Research. May 2020, v. 31, Issue 1.

HERRMANN, M.; BOEHME, P.; MONDRITZKI, T.; EHLERS, J. P.; KAVADIAS, S.; TRUEBEL, H. Digital Transformation and Disruption of the Health Care Sector: InternetBased Observational Study. Journal of Medical Internet Research. 2018, v. 20, n. 3, e. 104. HISRICH, R. D.; PETERS, M. P.; SHEPHERD, D. A. Empreendedorismo. 9. ed. Porto Alegre: AMGH. 2014.

HOLGERSSON, M.; GRANSTRAND, O. Patenting motives, technology strategies, and open innovation. Management Decision, 2017, v. 55, n. 6, p. 1265-1284.

JANNUZZI, A. H. L.; VASCONCELlOS, A. G.; DE SOUZA, C. G.. Especificidades do patenteamento no setor farmacêutico: modalidades e aspectos da proteção intelectual. Cadernos de Saúde Pública. Rio de Janeiro, RJ, 2008, v. 24, n. 6, p. 1205-1218.

KANE, G. C.; PALMER, D.; PHILlIPS, A. N.; KIRON, D.; BUCKLEY, N. Strategy, not Technology, Drives Digital Transformation. MIT Sloan Management Review - Research Report. Boston: 2015.

KAUFMANN, G. Two kinds of creativity - but which ones? Creativity and Innovation Management. 2004, v. 13, n. 3, p. $154-165$.

KLINE, S. J.; ROSENBERG, N. An Overview of Innovation. In: LANDAU, R.; ROSENBERG, N. (Org.) The Positive Sum Strategy: Harnessing Technology for Economic Growth. Washington: Andesite Press, 1986.

KRISHNA, R. The Emerging Role of Digital Technologies in Early Clinical Development. Clinical Pharmacology \& Therapeutics. 2018, v. 103, n 1.

LAURENS, P.; LE BAS, C.; SCHOEN, A. Worldwide IP coverage of patented inventions in large pharma firms: to what extent do the internationalisation of $R \& D$ and firm strategy matter? International Journal of Technology Management, Inderscience, 2019, v. 80, n. 3/4, p.177211. 
LIGA VENTURES. Liga Insights Health Techs. Disponível em: https://insights.liga.ventures/ healthtechs/. Acesso em 30 mar. 2019.

LIMA, J. S.; REZA, D.; TEIXEIRA, S.; COSTA, C. Pesquisa Clínica: fundamentos, aspectos éticos e perspectivas. Revista da Socerj. 2003, v. 16, n. 4, p. 225-233.

MORESI, E. (Org.). Metodologia de Pesquisa. Universidade Católica de Brasília, 2003.

NORONHA, J. C. de; NORONHA, G. S. de; PEREIRA, T. R.; COSTA, A. M. Notas sobre o futuro do SUS: breve exame de caminhos e descaminhos trilhados em um horizonte de incertezas e desalentos. Ciência \& Saúde Coletiva. Rio de Janeiro, 2018, v. 23, n. 6, p. 20512060.

OCDE. Manual de Oslo: diretrizes para coleta e interpretação de dados sobre inovação. Finep, $3^{\text {a }}$ Edição, 2005. Disponível em: https://www.finep.gov.br/images/apoio-efinanciamento /manualoslo.pdf. Acesso em 09 jun. 2019.

PEPE, V. L. E.; FIGUEIREDO, T. A.; SIMAS, L.; OSORIO-DE-CASTRO, C. G. S.; VENTURA, M. A judicialização da saúde e os novos desafios da gestão da assistência farmacêutica. Ciência \& Saúde Coletiva. Rio de Janeiro, 2010, v. 15, n. 5, p. 2405-2414.

PINCHOT III, G. Intrapreneuring: Why You Don't Have to Leave the Corporation to Become an Entrepreneur. New York: Harper \& Row, 1989.

PWC. Global Innovation 1000. Disponível em: https://www.strategyand.pwc.com/ innovation1000. Acesso em 30 mar. 2019.

QUENTAL, C.; ABREU, J. C.; BONTEMPO, J. V.; GADELHA, C. A. G. Medicamentos genéricos no Brasil: impactos das políticas públicas sobre a indústria nacional. Ciência \& Saúde Coletiva, 2008, v. 13, suppl., p. 619-628.

ROGERS, D. L. Transformação Digital: repensando o seu negócio para a era digital. São Paulo: Autêntica Business, 2017.

SABBAG, S. R. S. Fatores intervenientes na relação do sujeito com a organização: um estudo sobre o conceito de comprometimento organizacional. Dissertação de mestrado. São Paulo: USP, 2002. 
SALEH, S. D.; WANG, C. K. The Management of Innovation: Strategy, Structure, and Organizational Climate. IEEE Transactions on Engineering Management. 1993, v. 40, n. 1, p. $14-21$.

SCHUHMACHER, A.; GATTO, A.; HINDER, M.; KUSS, M.; GASSMANN, O. The upside of being a digital pharma player. Drug Discovery Today. 2020, v. 25, n. 9, september. p. 15691574.

SCHWAB, K. A Quarta Revolução Industrial. São Paulo: Edipro, 2016.

SCHWAB, K. Shaping the fourth Industrial Revolution. Geneva: World Economic Forum, 2018.

SESTElO, J. A. F.; DE SOUZA, L. E. P. F.; BAHIA, L. Saúde suplementar no Brasil: abordagens sobre a articulação público/privada na assistência à saúde. Cad. Saúde Pública, Rio de Janeiro, 2013, maio, v. 29, n. 5, p. 851-866.

SITKIN, S. Learning Through Failure: The Strategy of Small Losses. Research in Organizational Behavior. JAI Press Inc., 1992, v. 14, p. 231-266.

TELLES, R. A efetividade da matriz de amarração de Mazzon nas pesquisas em Administração. Revista de Administração, 2001, v. 36, n. 04, p. 64-72.

TRAPP, M.; VOIGT, K.; BREM, A. Business models for corporate innovation management: introduction of a Business Model Innovation tool for established firms. International Journal of Innovation Management. 2018, v. 22, n. 1.

U.S. DEPARTMENT OF HEALTH AND HUMAN SERVICES. FDA selects participants for new digital health software precertification pilot program. Disponível em: https://www.fda.gov/NewsEvents/Newsroom/PressAnnouncements/ucm577480.htm. Acesso em 30 mar. 2019.

VAN VELTHOVEN, M. H.; CORDON, C.; CHALLAGALLA, G. Digitization of healthcare organizations: The digital health landscape and information theory. International Journal of Medical Informatics. 2019, v. 124, p. 49-57.

WIPO. World Intellectual Property Indicators 2020. Geneva: World Intellectual Property Organization. 2020.

YIN, R. K. Estudo de caso: planejamento e métodos. 2.ed. Porto Alegre: Bookman, 2001. 
ZIBARRAS, L.; PORT, R.; WOODS, S. A. Innovation and the 'Dark Side' of Personality: Dysfunctional Traits and their Relation to Self-Reported Innovative Characteristics. Journal of Creative Behavior. 2008, v. 42, n. 3, p. 201-215. 